EUROPEAN CENTRAL BANK

WORKING PAPER SERIES

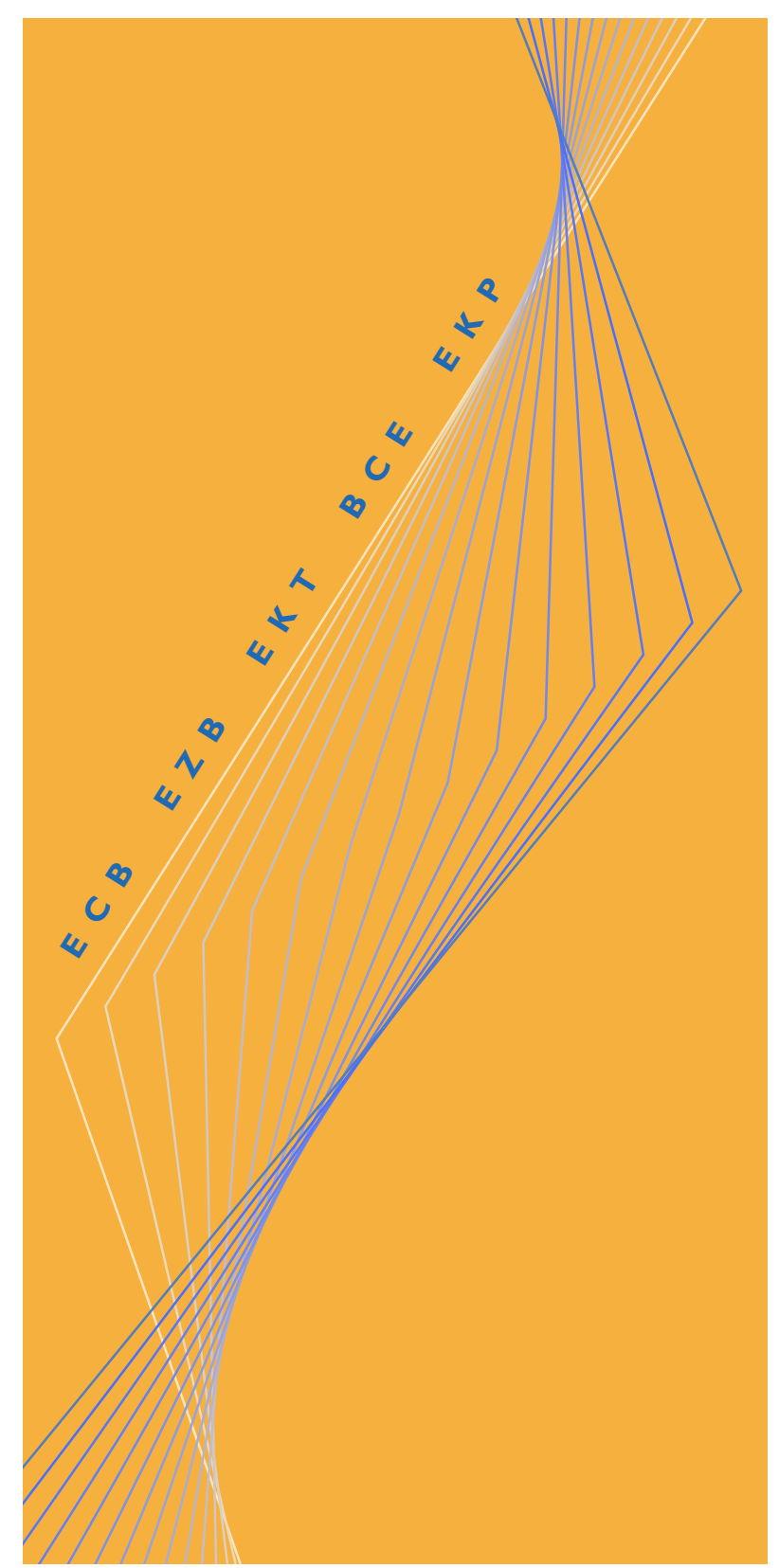

WORKING PAPER NO. 264

A MONTHLY MONETARY MODEL WITH BANKING INTERMEDIATION FOR THE EURO AREA

BY ANNICK BRUGGEMAN AND

MARIE DONNAY

September 2003 


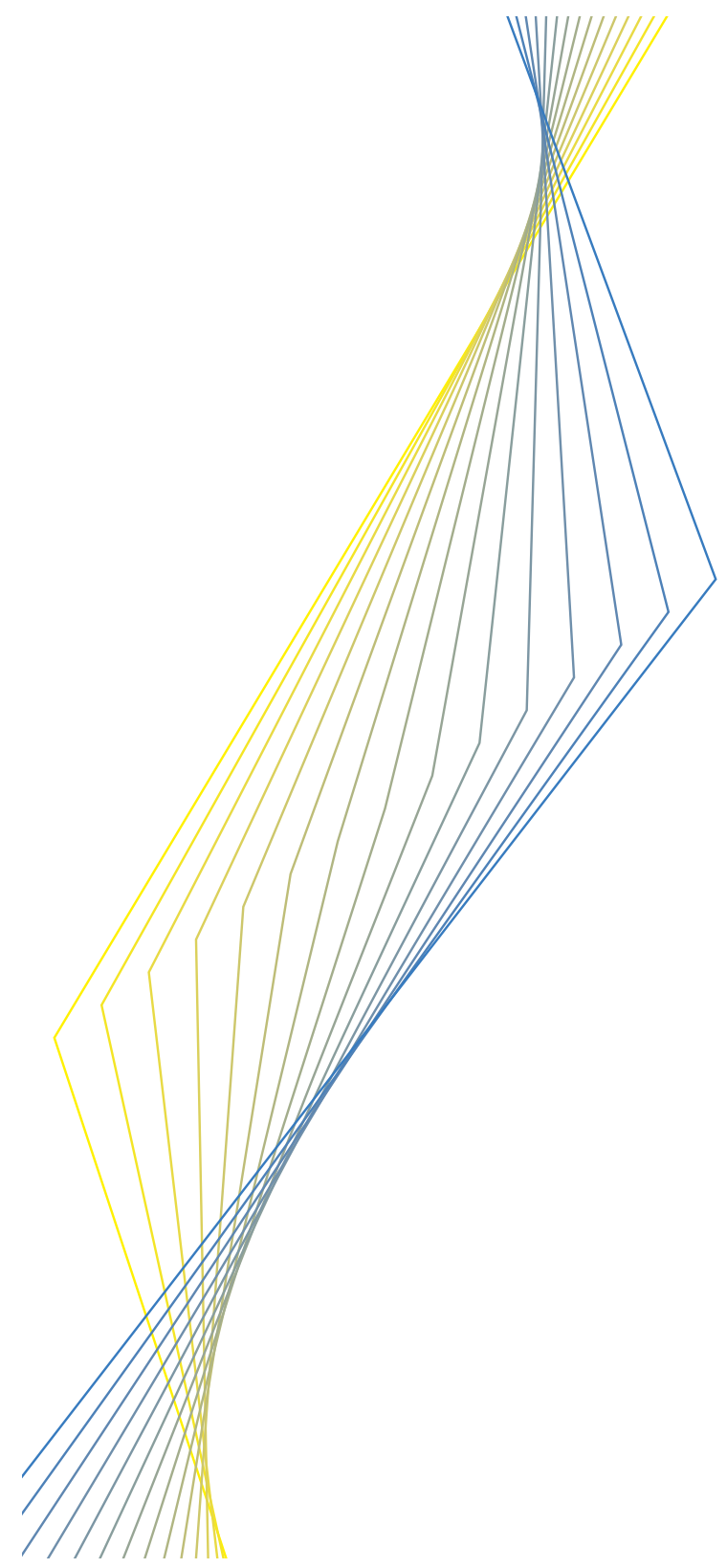

WORKING PAPER NO. 264

\section{A MONTHLY MONETARY MODEL WITH BANKING INTERMEDIATION FOR THE EURO AREA'}

\section{BY ANNICK BRUGGEMAN² AND MARIE DONNAY ${ }^{3}$}

\section{September 2003}

I We have greatly benefited from discussions with A. Calza, G. Coenen, G. de Bondt, J.L. Escrivá, B. Fischer, K. Hubrich, H.-J. Klöckers, K. Juselius, M. Manrique, J. Sousa, A. Warne and C.Willeke. N. Cassola and R. Mosconi, programmer of Malcolm, have been very helpful concerning the utilisation of Malcolm. Special thanks to F. Sédillot who provided the routines for the monthly interpolation of part of the dataset. Comments and suggestions by an anonymous referee are also gratefully acknowledged. The views expressed in this paper are those of the authors and do not necessarily reflect those of the European Central Bank. This paper can be downloaded without charge from http://www.ecb.int or from the Social Science Research Network electronic library at http://ssrn.com/abstract id=457532.

2 European Central Bank, Postfach I60319, D-60666 Frankfurt am Main, Germany. Email address: annick.bruggemann@ecb.int.

3 Center for Economic Studies, Catholic University of Leuven, Naamsestraat 69, B-3000 Leuven, Belgium. Email address: marie.donnay@econ.kuleuven.ac.be. The major part of the paper was written while Marie Donnay was visiting the Monetary Policy Stance Division of the ECB as a summer intern. 
() European Central Bank, 2003 Address

Kaiserstrasse 29

D-603 I I Frankfurt am Main

\section{Germany}

Postal address

Postfach 160319

D-60066 Frankfurt am Main

Germany

+496913440

Telephone

http://www.ecb.int

Internet

+496913446000

Fax

4 I I I 44 ecb d

Telex

All rights reserved.

Reproduction for educational and non-commercial purposes is permitted provided that the source is acknowledged. The views expressed in this paper do not necessarily reflect those of the European Central Bank.

ISSN I56I-0810 (print)

ISSN I725-2806 (online) 


\section{Contents}

$\begin{array}{lr}\text { Abstract } & 4\end{array}$

$\begin{array}{lr}\text { Non-technical summary } & 5\end{array}$

$\begin{array}{lr}\text { I. Introduction } & 7\end{array}$

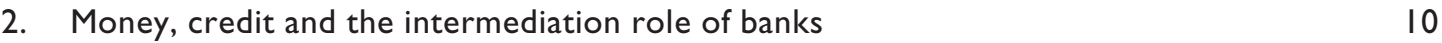

3. A monthly monetary model with banking intermediation for the euro area: a cointegration analysis

3.I. Monthly money demand model $\quad 16$

3.2. Monthly loan demand model 21

3.3. Monthly encompassing monetary model 26

4. A monthly monetary model with banking intermediation for the euro area: a dynamic analysis

$\begin{array}{ll}\text { 5. Conclusions } & 48\end{array}$

$\begin{array}{ll}\text { References } & 53\end{array}$

$\begin{array}{lr}\text { Appendices } & 57\end{array}$

$\begin{array}{ll}\text { European Central Bank working paper series } & 75\end{array}$ 


\begin{abstract}
:
This monthly monetary model for the euro area is gradually constructed from its two constituting components: a money demand and a loan demand model which both include the relation between the respective retail bank rates and the short-term market interest rate. Eventually, the encompassing monetary model allows for interactions between money and loans induced by the intermediation role of the banking sector.

Estimating the encompassing model over the period January 1981 - September 2001 results in a money demand equation which corroborates the existing evidence. To stabilise the loan demand equation, however, an extra variable capturing the mergers and acquisitions wave of 1999-2000 is needed. Furthermore, the model rejects the frequently used assumption of complete separability in the pricing of loans and deposits and provides some evidence for the existence of a bank lending channel. Finally, the estimation of the Structural-VECM highlights very rich dynamics in the system.
\end{abstract}

Key words: Cointegration, Structural VECM, Money demand, Loan demand, Banking intermediation.

JEL classifications: C32, E41, E43, E50, G21. 


\section{Non-technical summary}

This paper combines several aspects of monetary analysis: money demand, loan demand and banking intermediation in the euro area. We start by estimating separately a monthly money demand and a monthly loan demand model. These smaller models are subsequently used as a starting point for the identification of the encompassing monetary model.

As a first step, a monthly money demand model is estimated in which the bank intermediation is modelled by means of the pass-through from the short-term market interest rate to a synthetic retail bank deposit rate, called the own rate of M3. The results indicate that the demand for M3 depends positively on real GDP and negatively on the opportunity costs, i.e. the spread between the short-term market interest rate and the own rate of M3. Compared with existing quarterly evidence, our results do not seem to be affected by the use of monthly data nor by the inclusion of the short-term market interest rate and the own rate of M3 separately. This results, however, in the presence of a second long-run relationship, that can be interpreted as the long-run pass-through which is found to be incomplete, in line with the existing literature. Overall, the stability properties of the money demand model are satisfactory, although a slight gradual increase in the pass-through to the deposit rates can be observed since 1999 .

In a similar vein, a monthly loan demand model is estimated in which the bank intermediation is modelled by means of the pass-through from the short-term market interest rate to a synthetic retail bank lending rate, called the composite lending rate. Unlike in existing empirical evidence, an exogenous variable capturing the real cash value of mergers and acquisitions of euro area non-financial corporations and the UMTS licenses has been included to improve the stability of the long-run parameters of the model. The estimated parameters indicate that in the long-run the demand for real loans depends positively on real GDP and the exogenous variable and negatively on the real cost of bank lending, i.e. the spread between the composite lending rate and the inflation rate. Although the inclusion of the exogenous variable results in much more stable parameter estimates, both the income elasticity and the real bank lending cost semi-elasticity increase somewhat towards the end of the sample. The second long-run relationship can be interpreted as the long-run pass-through from the short-term market interest rate to the composite lending rate. 
When comparing the results of the two separate models, it becomes evident that the link between M3 and the own rate of M3 is much weaker than the link between loans and the composite lending rate. In addition, the pass-through of the short-term market interest rate to the retail bank lending rates is estimated to be both quicker and stronger than the pass-through to the retail bank deposit rates. Both these findings are confirmed by the results of the monthly encompassing monetary model with banking intermediation.

Overall, the results of the smaller money demand model are recovered fairly well in the encompassing monetary model, but the same does not hold for the results of the smaller loan demand model. While the inclusion of the exogenous variable resulted in a broadly stable long-run loan demand equation in the small model, it is insufficient to fully stabilise the parameter estimates of the real loan demand equation in the encompassing model. A second difference between the smaller loan demand model and the encompassing monetary model is the long-run pass-through to the composite lending rate. The encompassing model suggests that there exists a positive long-run relationship between the banks' intermediation margin and the short-term market interest rate and that the links between the two retail bank interest rates and the shortterm market interest rate are rather complex in the short term. This suggests that banks do not consider the money market to be a perfect substitute for deposits when raising funds, which could be seen as a necessary (but not sufficient) condition for the existence of a bank lending channel.

To further analyse the dynamics of the encompassing monetary model impulse response functions and forecast error variance decompositions have been simulated following the method of the common trends. The three identified permanent shocks an aggregate supply shock, a nominal or inflation objective shock and an institutional shock reflecting changes in labour market flexibility - are responsible for the main variability of the endogenous variables in the system, in particular in the long run. The four identified temporary shocks - a money demand shock, a loan demand shock, a banking shock and a monetary policy instrument shock - have only a limited impact which is restricted to the short and medium run. 


\section{Introduction}

Since the European Central Bank assumed all responsibility for the single monetary policy in the euro area, it has repeatedly asserted the importance it attaches to monetary and credit aggregates. A close monitoring of the developments in M3 and loans to the private sector is the cornerstone of the first pillar of its monetary policy strategy.

This interest in monetary developments is obvious given the general agreement on the monetary nature of inflation in the long run. The stable link between the broad monetary aggregate M3 and prices has been established by numerous empirical studies. Moreover, the availability and the accuracy of monetary data have proven to be superior to many other economic indicators (Issing, 2001).

Besides the analysis of M3 and its components, a deeper study of its main counterparts - the most important one being loans to the private sector - is of major interest. The developments in loans to the private sector provide some additional insights into monetary and economic conditions, and the appropriate monetary policy to be implemented.

Bernanke and Blinder (1988) recommend a "more symmetric treatment of money and credit". Despite the importance of monitoring the developments in M3 together with the developments in loans to the private sector, little empirical work has been dedicated to the possible interactions between these two aggregates and their relations with the banking sector behaviour.

One issue this paper investigates is the possible link between M3 and loans to the private sector that may result from the necessary equilibrium between the asset and liability sides of the banks' balance sheets. This link has been acknowledged in the theoretical literature analysing the banking sector as a financial intermediary ${ }^{4}$, but up to now little empirical evidence has been reported at the European level ${ }^{5}$.

Similarly, attention is paid to the related issue of the retail bank interest rates, i.e. the interest rates banks charge for loans and pay on deposits. The organisation approach of banking provides an interesting theoretical framework to investigate the determinants of and the link between these retail bank interest rates. While most

$4 \quad$ Fama (1985), Allen and Santomero (1998), Stein (1998), Diamond and Rajan (2000), Kashyap and Stein (2000) and Kashyap, Rajan and Stein (2002).

5 Except for, to some extent, Brigden and Mizen (1999) and Chrystal and Mizen (2001a, 2001b) for the UK. 
studies for the euro area, as e.g. Mojon (2000) and de Bondt (2002), discuss the passthrough of the retail bank interest rates for the euro area (adjustments in the lending and deposit rates after a change in the monetary policy rate), they do not allow for a link between the two types of retail bank interest rates. However, in more recent work, de Bondt, Mojon and Valla (2003) perform single equation Granger causality tests to examine whether the retail bank rate on time deposits has predictive power for several types of retail bank lending rates over and above short- and long-term market interest rates and conclude that this is not the case.

To our knowledge, there exists no study that combines all these elements (M3, loans, deposit rates and lending rates) in an encompassing framework, in an attempt to highlight their interdependence and account for the intermediation role that banks play in the monetary transmission in the euro area.

Against this background, the purpose of this paper is twofold.

First, we concentrate on the demand for M3 and on the demand for loans by the private sector separately and extent the existing empirical literature in two directions. So far, the existing money demand and loan demand models at the European level were based on quarterly data ${ }^{6}$. An important part of the monetary analysis, however, is based on monthly monetary statistics. Therefore, a better understanding of the demand for M3 and of the demand for loans by the private sector at a higher frequency could help to further improve the regular assessment of monetary and credit developments. In addition, we emphasise the role of banking intermediation by investigating the dynamics of a synthetic retail bank deposit rate - the own rate of return of M3 - and of a synthetic retail bank lending rate, the composite lending rate. In this way, we gain more insight into euro area money and loan demand respectively and into the setting of the retail bank interest rates.

However, since it seems reasonable to expect links between the two banking activities and their respective interest rates, the second purpose of this paper is to combine both activities of the banking sector by pooling M3, the own rate of M3, loans to the private sector and the composite lending rate in one encompassing monetary system with banking intermediation.

Except for the monthly money market model of the Bank of Italy (Angeloni (1994)). This is a very large structural model containing 170 equations designed for operational purposes. 
A better understanding of the interactions between these variables should give further insights into the overall monetary situation in the euro area economy. Considering these variables simultaneously may e.g. help to identify potential instabilities of money and/or loan demand by comparing their parallel development over time. A strong increase in loan growth that is not accompanied by a strong increase in money growth could e.g. be seen as an indication of euro area investors' high demand for loans to finance their direct and portfolio investment abroad. Similarly, a strong rise in money growth combined with moderate loan growth could signal an increased liquidity preference of euro area investors, e.g. at times of high financial market uncertainty.

In addition, the encompassing monetary model permits to analyse a number of aspects of the monetary policy transmission mechanism in the euro area. First, evidence can be gathered regarding the importance of a bank lending channel in the euro area, by analysing whether loan developments react to developments in M3. Second, this encompassing setting permits to test how changes in the short-term market interest rate are transmitted to the bank retail rates allowing for interdependence between the lending and the deposit rates. Finally, a more general picture of the monetary policy transmission mechanism can be obtained by looking at the dynamics of the whole system allowing for the interplay of all variables.

The remainder of this paper is organised as follows. In the next section, we shortly review some of the existing literature on the different issues studied in this paper, i.e. some empirical studies on money and loan demand in the euro area, the literature on possible links between money and loans and, in particular, on the bank lending channel, and finally, the literature on the price setting in the banking sector and on the pass-through of market interest rates to retail bank interest rates. The third section is dedicated to the cointegration analysis and the identification of three models for the euro area: a monthly money demand, a monthly loan demand and a monthly encompassing monetary model. These three systems are estimated and evaluated, successively, following the method of Johansen (1995). The fourth section focuses on the dynamic analysis, in particular of the encompassing monetary model. The structural identification of the vector error correction model is carried out following the approach of the common trends of Warne (1993) on the basis of which impulse 
response functions and forecast error variance decompositions are simulated. Finally, Section 5 concludes and suggests some possible further research.

\section{Money, credit and the intermediation role of banks}

The study of money demand has always been a key issue for the conduct of monetary policy. Numerous recent studies for Germany and the euro area (amongst others Vlaar and Schuberth (1999), Brand and Cassola (2000), Coenen and Vega (1999, 2001), Hubrich and Vlaar (2003), Calza, Gerdesmeier and Levy (2001), and Cassola and Morana (2002)) have found a stable relation between money and prices, and discuss the interactions between money and the real sector ${ }^{7}$. In a standard money demand model, money (i.e. aggregate M3) is related to the price level, a scale variable (real GDP) and the opportunity costs of money (interest rates and the inflation rate). The method usually applied is either a single equation error-correction model or a cointegrated vector autoregressive model, also known as vector error correction model (VECM). The above-mentioned studies investigate different variants of this standard system. The contribution of Calza, Gerdesmeier and Levy (2001) is of particular interest for our analysis since their opportunity cost measure is based on a synthetic deposit rate instead of on market interest rates only. It is defined as the spread between the short-term market interest rate and an own rate of return of euro area M3 constructed on the basis of retail bank deposit rates. Unlike Calza, Gerdersmeier and Levy, we include the short-term market interest rate and the own rate of M3 as separate variables, but our results turn out to be very similar to theirs. The last part of this paper is in line with the approach followed by Coenen and Vega (1999), Hubrich and Vlaar (2003) and Cassola and Morana (2002), in that we also develop a structural vector error correction model (S-VECM) that allows the estimation of impulse response functions and forecast error variance decompositions to study the dynamics of the model.

Compared with the large amount of money demand studies for the euro area, the empirical literature on loan demand in the euro area is rather scarce. To our knowledge only Calza, Gartner and Sousa (2003) and Calza, Manrique and Sousa

7 For a good methodological survey of the literature on error correction money demand models (including also non-European countries) see Sriram (1999). 
(2003) estimate a quarterly loan demand model for the euro area ${ }^{8}$. Both studies identify one stable cointegrating relationship linking real loans, real GDP and one or more interest rate variables capturing the lending cost. The study of Calza, Manrique and Sousa (2003) is comparable to our analysis, in that their sample period also includes the unprecedented increase in real loans to the euro area private sector in 1999 and 2000. The authors relate it inter alia to a major wave of mergers and acquisitions (both inside and outside the euro area) ${ }^{9}$ and to the large financing needs of telecommunication companies for the UMTS licences. While these factors seem to introduce some instability in their estimated long-run real loan demand equation in 2000, the long-run coefficients appear to return to their historical levels afterwards, suggesting that these underlying destabilising factors were of a temporary nature.

In the academic literature, several authors legitimise the attention paid, by the practitioners, to both sides of the commercial banks' balance sheets when assessing the overall monetary situation. Furthermore, they describe the links between the deposit and credit aggregates and underline the intermediation role of banks in the monetary transmission process.

A first strand of this literature stresses the special character of commercial banks with respect to other financial intermediaries. Fama (1985) observes that borrowers are willing to pay higher costs for bank loans than those they could possibly incur with a direct financing on the financial markets. At the same time, depositors earn less on bank deposits than on some other financial instruments (non-bank securities) of equivalent risk. "There must be something special about banks that prevents other intermediaries from competing to assure that it never pays to finance loans with $C D$ 's." ${ }^{10}$ Fama argues that bank borrowers are also bank depositors. This gives banks a competitive advantage in overcoming information asymmetries and transaction costs for the making and monitoring of their loans. Diamond and Rajan (2000) present another rationale to explain the "important social role of banks": risk management. The banks bear the maturity risk (they transform short-term deposits into long-term loans) and control their intermediation margin.

8 For an overview of existing loan demand models for the individual euro area countries see Calza, Manrique and Sousa (2003).

9 Mergers and acquisitions of the non-financial sector were partly financed by bank loans.

10 Fama (1995), p. 112. 
Stein (1998) extends further this analysis and links the above-mentioned strand of literature with the monetary transmission literature, particularly the credit view. Hence, his paper concurs with the seminal papers of Bernanke and Blinder (1992), Gertler and Gilchrist (1993), Bernanke (1993), and Bernanke and Gertler (1995) on the bank lending channel and the balance sheet channel of monetary transmission. The bank lending channel postulates the absence of perfect substitutes to the bank deposits for the financing of banks. Therefore a restrictive monetary policy, that with some lag results in a contraction of the deposits, may force the banks to reallocate their assets portfolio by, for instance, reducing the supply of loans ${ }^{11}$. In the balance sheet channel, a tightening of monetary policy induces a fall in the net wealth of borrowers, a drop in the value of the collateral and an intensification of the moral hazard and adverse selection problems which lead banks to restrict the supply of loans. A criticism frequently addressed to the credit view and to numerous structural vector autoregressive (S-VAR) analyses is the difficulty to distinguish the supply and demand factors at work. A restrictive monetary policy e.g. also depresses the economy, which in turn, may curb the demand for loans.

The evidence on the relevance of the broad credit channel in Europe is relatively mixed. Angeloni, e.a. (2002) summarise the results of a number of empirical studies conducted within the Eurosystem in the context of the Monetary Transmission Network. ${ }^{12}$ They conclude that the bank lending channel seems to have been operating significantly in Germany, Italy and Greece, while it appears not to be important in some other euro area countries. However, the fact that banks still finance the bulk of investment (private and public) in Europe constitutes a good reason for investigating their impact on the monetary transmission process. Eventually, this strand of literature highlights again the interactions between money and loans, the importance of the banking sector and the possible consequences for the transmission mechanisms of monetary policy.

11 Monetary policy affects the deposits indirectly - via its effect on market interest rates and real economic activity - and therefore only with a lag. Note also that the increasing availability of financing on the financial markets, the existence of relationship banking and other institutional factors may soften the possible impact of the bank lending channel.

12 The research conducted within this Monetary Transmission Network was presented at the ECB Conference on "Monetary policy transmission in the euro area" on 18-19 December 2001 and the proceedings of this conference will be published in Angeloni, Kashyap and Mojon (2003). The results of the individual contributions have also been published as ECB Working Papers. 
Finally, another related strand of literature considers the setting of the interest rates on loans and deposits by the banking sector. It is these rates that provide the first link in the mechanism for the transmission of the monetary impulses that arise from changes in official interest rates. Therefore, a study of the determinants of the retail bank interest rates proves to be complementary to the traditional monetary analysis.

The industrial organisation approach of banking ${ }^{13}$, particularly the Monti-Klein model, provides an interesting theoretical starting point to investigate the determinants of the retail bank interest rates. The Monti-Klein model establishes the link between the retail rates, on the one hand, and the policy rate and the elasticities of the loan demand or the deposit supply ${ }^{14}$, on the other hand, assuming a perfect separability between the deposit and the lending rates (Freixas and Rochet (1997)). In this context, several theoretical studies have provided the rationales for the existence of price rigidities in the banking sector. Hannan and Berger (1991) develop a model for the setting of bank deposit rates and find that the degree of stickiness of the deposit rates depends on the concentration of the markets ${ }^{15}$. Turning to the lending rates, Berlin and Mester (1998) show that, in the context of relationship lending, banks smooth their lending rates in response to an interest rate shock as part of an optimal contract between the borrower and the bank ${ }^{16}$. Regarding empirical work for Europe ${ }^{17}$, Mojon (2000), de Bondt (2002) and de Bondt, Mojon and Valla (2003) consider the adjustments in the lending and deposit rates after a change in the monetary policy rate, also called pass-through. They provide measures of the retail bank interest rate stickiness and the (in)completeness of the pass-through ${ }^{18}$ and highlight country differences in Europe. The determinants of this pass-through are: the monetary policy regime, the intensity of competition in the banking sector, the availability of alternative financing, the development of financial markets and some internal features of banks (ownership, operating costs and pricing strategies). They also find some evidence of acceleration in the pass-through since the introduction of the euro. This is an important finding since a quicker pass-through of official rates to retail bank interest rates reinforces the

See Chapter 3 of Freixas and Rochet (1997).

Which in turn are characteristic of the banking structure and the market power of banks.

They also find that the deposit rates are more rigid upwards than downwards.

See also Berger and Udell (1992).

Cottarelli and Kourelis (1994), Borio and Fritz (1995) include also non-European countries.

18 In general, the deposit rates are found to be stickier than the lending rates (see e.g. Mojon (2000) and de Bondt (2002)). In the remainder of this paper, we will refer to the "long-term pass-through" as the long-term link between the monetary policy rate and the bank retail rates, as opposed to the short-term adjustment of the retail bank interest rate following a deviation from its long-term equilibrium which will be labelled "short-term pass-through". 
monetary transmission, the impact on money and loans, and possibly, on the real economy.

Dermine (1986), Stahl (1988) and Yanelle (1989, 1997) revisit the Monti-Klein model and allow for interdependence between the two retail bank interest rates. The banks compete on both sides of the market simultaneously (double Bertrand competition). The deposit rates and lending rates are linked in a sequential game and its outcome depends on the assumed trading structure. "I suppose that intermediaries compete on both sides of the market, i.e. on the market for funds and on the market for investment projects. These two markets are obviously interrelated because a bank cannot finance a project unless it has the fund to do so. Because of this interrelation, two game specifications must be distinguished: In one specification the banks' purchases of funds are limited by the demand for credit they receive from the borrowers; in the other specification the banks' dispensation of credit to borrowers is limited by the funds they receive from the lenders in the form of deposits "19. According to Stahl (1988), one possible outcome of the game is to compete on the lending rates in order to maximise the revenue of the loans and to then fix the deposit rates in accordance with this objective. This interdependence between the two rates is also verified in practice when the commercial banks decide on the intermediation margins (the positive spread between their lending and their deposit rates) ${ }^{20}$. Furthermore, Chiappori, Perez-Castrillo and Verdier (1995) highlight the impact of deposit rate regulation on the credit rates and the possible cross-subsidisation between the two activities. Regarding empirical work for Europe, de Bondt, Mojon and Valla (2003) do not find evidence of retail bank lending rates being affected by the retail bank rate on time deposits.

\section{A monthly monetary model with banking intermediation for the euro area: a cointegration analysis}

This section is dedicated to the estimation of the cointegrating models. We gradually construct the encompassing monetary model on the basis of its two constituting components: money demand and loan demand. Each of the three models integrates the banking system by including the retail bank interest rates in the form of a synthetic

\footnotetext{
19 Yanelle (1989), p. 298.

20 See also Diamond and Rajan (2000).
} 
deposit and/or lending rate. While this representation of the banking system may seem incomplete, since it is reduced to its price setting behaviour, also the theoretical literature indicates that the strategic behaviour of banks relies to a large extent on their price setting ${ }^{21}$. Therefore, we believe that the dynamics of the retail bank interest rates setting may complement the analysis of the monetary and credit aggregates, namely the deposits (money) and the loans.

The main purpose of the money and the loan demand models is to cross-check the available empirical evidence for the euro area for the monthly frequency and the modelling of the pass-through from the monetary policy instrument to the retail bank deposit and lending rates. In addition, these smaller models are used as a starting point for the identification of the encompassing monetary model.

The benchmark model is described as follows: $\left[\begin{array}{lllll}y & \pi & I R S & R R & A g g\end{array}\right]^{\prime}$, where $R R$ denotes the retail bank interest rate, i.e. the own rate of $\mathrm{M} 3$ and/or the composite lending rate and Agg the real monetary aggregate M3 and/or real loans to the private sector. The three other variables are the standard ones in a macro-econometric VAR system: $y$ is real GDP as the scale variable, $\pi$ is inflation ${ }^{22}$ and IRS stands for the monetary policy instrument (the short-term market interest rate).

For each model, the method of Johansen (1995) is applied using the following generalisation of the standard reduced form of the partial $\mathrm{VECM}^{23,24}$ :

$$
\Delta \mathbf{Y}_{t}=\sum_{i=1}^{k-1} \boldsymbol{\Gamma}_{y, i} \Delta \mathbf{Y}_{t-i}+\sum_{i=1}^{k-1} \boldsymbol{\Gamma}_{z, i} \Delta \mathbf{Z}_{t-i}+\mathbf{\Psi} \mathbf{D}_{t}+\boldsymbol{\Theta} \mathbf{W}_{t}+\boldsymbol{\alpha} \boldsymbol{\beta}^{\prime}\left[\begin{array}{c}
\mathbf{Y}_{t-1} \\
\mathbf{Z}_{t-1}
\end{array}\right]+\boldsymbol{\varepsilon}_{t}
$$

where $\mathbf{Y}_{t}$ is the vector of the endogenous variables, $\mathbf{Z}_{t}$ is the vector of the exogenous variables, $\mathbf{D}_{t}$ represents the deterministic components, $\mathbf{W}_{t}$ is the vector of the intervention dummies, $\boldsymbol{\alpha}$ is the matrix of adjustment speeds of the endogenous variables for each error correction term (ECT), $\boldsymbol{\beta}^{\prime}\left[\begin{array}{l}\mathbf{Y}_{t-1} \\ \mathbf{Z}_{t-1}\end{array}\right]$ is the ECT - obtained by multiplying the endogenous and the exogenous variables with the long-run

$21 \quad$ See Freixas and Rochet (1997), Chapter 3.

22 Contrary to what is done for the loan demand and the encompassing monetary models - in which we want to test whether loan demand is affected by the nominal or the real composite lending rate - inflation is not included in the money demand model for reasons of parsimony.

23 The estimations are carried out with PcFiml, that is the cointegration routine provided by PcGive.

24 The VECM is said to be partial because the equation for the exogenous (the marginal model) is not represented here. It could be defined in a similar way though, except for the error correction term and the adjustments coefficients that do not enter the equation. 
coefficients included in the matrix $\boldsymbol{\beta}$ - and $\boldsymbol{\varepsilon}_{t}$ is the vector of the residuals. The cointegrating vectors are identified by imposing restrictions on the $\boldsymbol{\alpha}$ and $\boldsymbol{\beta}$ coefficients. An endogenous variable for which all $\boldsymbol{\alpha}$ coefficients can be set equal to zero is said to be weakly exogenous (Engle, Hendry and Richard (1983)).

For each model we concentrate on the analysis of the ECTs and present the tables of the estimated cointegration coefficients ( $\boldsymbol{\beta}$ coefficients) and adjustment speeds or feedback coefficients ( $\boldsymbol{\alpha}$ coefficients). The stability of the estimates is evaluated by means of the recursive graphs of the parameters of the cointegrating vectors. The accuracy of the model is checked by means of a Likelihood ratio test, henceforth also LR test.

The dataset includes real GDP, HICP inflation, real M3, real loans to the private sector, the three-month market interest rate, the own rate of return of M3, the composite lending rate and a series of the real amount of cash payments involved in merger and acquisition transactions of euro area corporations and the UMTS licenses. All variables are taken in natural logarithms, except for the interest rates and inflation, which are expressed in decimals, and the cash value of mergers and acquisitions which is in $€$ billions. The sample ranges from January 1981 until September 2001 with a monthly frequency ${ }^{25}$. The monthly series for real GDP and the GDP deflator used to deflate M3, loans and the cash value of mergers and acquisitions were interpolated with the Chow and Lin procedure (1971). Appendix I details further the construction and characteristics of the dataset ${ }^{26}$.

\subsection{Monthly Money Demand Model}

The monthly money demand model is estimated using the following four variables: real money (Rmoney), the own rate of return of M3 (MOR), the short-term market interest rate (IRS) and real GDP (GDP). The purpose is to identify a long-run real money demand equation while accounting for the link between the monetary policy instrument (IRS) and the synthetic retail bank deposit rate (MOR). The selection of the number of lags is based on the absence of autocorrelation in the system and on a concern for parsimony, hence the choice of 6 lags. The selection of 6 lags for each of the four endogenous variables included in this model is in line with the use of 2 lags

25 Due to the poor quality of the monthly interpolations of real GDP and the GDP deflator for the year 1980, these first observations were dropped from this study.

26 Prior to the cointegration analysis, unit root tests have been carried out and revealed that all variables were $\mathrm{I}(1)$. The results are available upon request. 
in most quarterly money demand models. Four impulse dummy variables are added for May 1993, March 1995, January 1999 and June 2000. The first two dummies are meant to correct for some joint outliers in IRS and MOR, while the other two dummies correct for some outliers in Rmoney ${ }^{27}$. The deterministic term chosen is an unrestricted constant, hence we allow for a linear trend in the I(1) variables.

Johansen's trace test statistics can be found in Appendix II (Table AII. 1). The inclusion of four dummies affects the asymptotic distribution and thus the critical values for this test statistic. Although the statistics computed with the dummies are accurate, they cannot be compared with the critical values provided in the table. Exploratory simulations in DisCo (Johansen and Nielsen (1993)), however, indicate that including dummies in the system would result in lower critical values than the ones reported in the table. As another indication, one can also resort to the test statistics for the system without dummies. Therefore, the trace test can be interpreted as indicating a rank of two at the 5\% significance level. This result is in line with our conjectures about the presence of two cointegrating vectors. First, the existence of a long-run demand for money equation has been extensively documented in the past on the basis of quarterly data. Second, the existing work on the interest rate pass-through between the monetary policy instrument and the deposit rates hinted to a possible long-run relation between these two interest rates, which would embody the intermediation role of the banking sector.

In order to identify the two cointegrating vectors several restrictions on the long-run coefficients and on the adjustment speeds are imposed and tested. The selection criteria used are an LR test on the validity of the restrictions and the stability of the long-run relations. While several representations are possible - as all linear

27 In May 1993 and March 1995 the month-on-month change in both the short-term market interest rate and the retail bank deposit rates was exceptionally large. While the average monthly change (in absolute values) amounts to 21 and 7 basis points for IRS and MOR respectively, these interest rates declined by 77 and 34 basis points in May 1993 and increased by 100 and 33 basis points in March 1995. The strong increase in M3 in January 1999 was related to the introduction of new statistical reporting systems, the introduction of the remunerated minimum reserves (which led to a flowback of funds into the euro area), changes in tax laws in some euro area countries and financial market uncertainties related to the transition to Stage Three of EMU. The sharp drop in M3 in June 2000 was related to a shift of funds from the overnight deposits of the money holding sector to those of the central government, in particular in Italy but to a smaller extent also in Germany. 
combinations of the genuine vectors are acceptable - the following model could not be rejected by the data (see Table 1 and Table 2).

Table 1: The cointegrating vectors of the money demand model

\begin{tabular}{lcccc}
\hline & Rmoney & MOR & IRS & GDP \\
\hline ECT 1 & 1 & -0.766 & 0.766 & -1.338 \\
& & & {$[0.336]$} & {$[0.040]$} \\
ECT 2 & 0 & 1 & -0.513 & 0 \\
& & & {$[0.035]$} & \\
\hline
\end{tabular}

Note: Standard errors are between brackets.

Table 2: The adjustment speeds of the money demand model

\begin{tabular}{lcc}
\hline & ECT 1 & ECT 2 \\
\hline Rmoney & -0.051 & 0 \\
MOR & {$[0.015]$} & \\
& 0 & -0.036 \\
IRS & -0.025 & {$[0.010]$} \\
& {$[0.010]$} & 0 \\
GDP & 0 & 0 \\
\hline
\end{tabular}

Note: Standard errors are between brackets.

The first cointegrating vector represents the long-run demand for money which is found to be positively related to real GDP and negatively to the opportunity costs of holding M3. The latter is tested to be represented by the spread between the shortterm market interest rate and the own rate of return of M3:

Rmoney $=c_{1}+1.338 * G D P-0.766 *(I R S-M O R)+\varepsilon$

These estimates corroborate the previous findings of the quarterly model of Calza, Gerdesmeier and Levy (2001) where the income elasticity of money demand was 1.34 and the opportunity costs (spread) semi-elasticity was -0.86. Also the adjustment speed of real money to a deviation from its long-run equilibrium value does not differ significantly between both models, although our monthly estimate of -0.051 suggests a somewhat quicker adjustment than their quarterly estimate of -0.116 . Hence, our estimates of the money demand equation do not seem to be affected much by the monthly frequency of the data nor by the presence of a second cointegrating vector. 
This second long-term relation embodies the long-run equilibrium between the monetary policy instrument and the retail bank deposit rates, also called long-run pass-through $^{28}$ :

$$
M O R=c_{2}+0.513 * I R S+\varepsilon
$$

These estimates for the synthetic deposit rate are in line with the results of de Bondt (2002) who analysed the pass-through for several types of deposits separately. His estimates of the long-run pass-through over the period 1996-2001 range between a low of 0.35 for the interest rate on short-term savings deposits and a high of 0.98 for the interest rate on short-term time deposits. The incomplete pass-through can be explained by a number of factors, such as e.g. the existence of menu costs for the banks which render adjusting deposit rates expensive, the existence of switching costs for the depositors which make it less likely that they will shift certain types of deposits to competing banks, a relatively weak competition between banks on the deposit segment of the retail bank market and the uncertainty about the future developments in the short-term market interest rate.

Regarding the adjustment coefficients, one interesting feature is the adjustment speed of the deposit rate to a deviation from its long-run equilibrium. This is, in other words, part of the "short-term pass-through" (assuming that a monetary policy change can push the MOR away from its equilibrium). When the deposit rate was above the level determined by its long-run relationship with the short-term market interest rate, banks have on average lowered their deposit rates to bring them back in line with their longrun equilibrium although the adjustment of the deposit rate within the next month is modest, which confirms the stickiness of this retail bank interest rate emphasised in the pass-through literature. There is also an indirect influence of money demand on the own rate of M3. Indeed, the short-term market interest rate reacts to a disequilibrium in the money demand equation ${ }^{29}$, while the MOR follows the IRS.

28 The denomination of the second vector as "pass-through" does not correspond exactly to the concept presented in Mojon (2000) and de Bondt (2002), where the "short-run" pass-through is the dynamics of adjustment after a monetary policy change.

29 The adjustment coefficient has the wrong sign though, yet this is a common and unexplained feature in the money demand literature (see e.g. Brand and Cassola (2000), Calza, Gerdesmeier and Levy (2001) and Cassola and Morana (2002)). This coefficient measures the average reaction of the short-term interest rate over the sample period considered. Therefore, a tentative explanation could be that the estimate is 'dominated' by the developments in the period 1993-94, during which the monetary overhang (ECT1) was exceptionally high - due to the sharp decline in real economic activity - while the short-term market interest rate fell sharply (see Chart AII. 1 and Chart AI. 1 in Appendix II and Appendix I respectively). 
Therefore, a deviation of money demand also impacts on the MOR, albeit with a longer lag. Regarding the short-run dynamics of GDP, the constraints imposing its weak exogeneity are not rejected by the data.

Both long-run relations, as they are identified, appear to be fairly stable over time, as can be assessed in Chart 1. At the same time, the latter suggests that the long-run relation between the own rate of M3 and the short-term market interest rate has become slightly stronger since 1999. This may be related to an increasing degree of competition in the deposit market, which forces banks to follow the development of the short-term market interest rate more closely. Another factor that could have influenced the magnitude of the long-term pass-through is the volatility of monetary policy. The less volatile monetary policy of the recent years may, therefore, also explain the slight rise in the adjustment of the own rate of M3 to the developments in the short-term market interest rate. However, since the change in the coefficient is not statistically significant, the importance of these factors should not be overstated.

\section{Chart 1: Recursive estimates of the long-run coefficients $(+/-2 *$ standard error)}
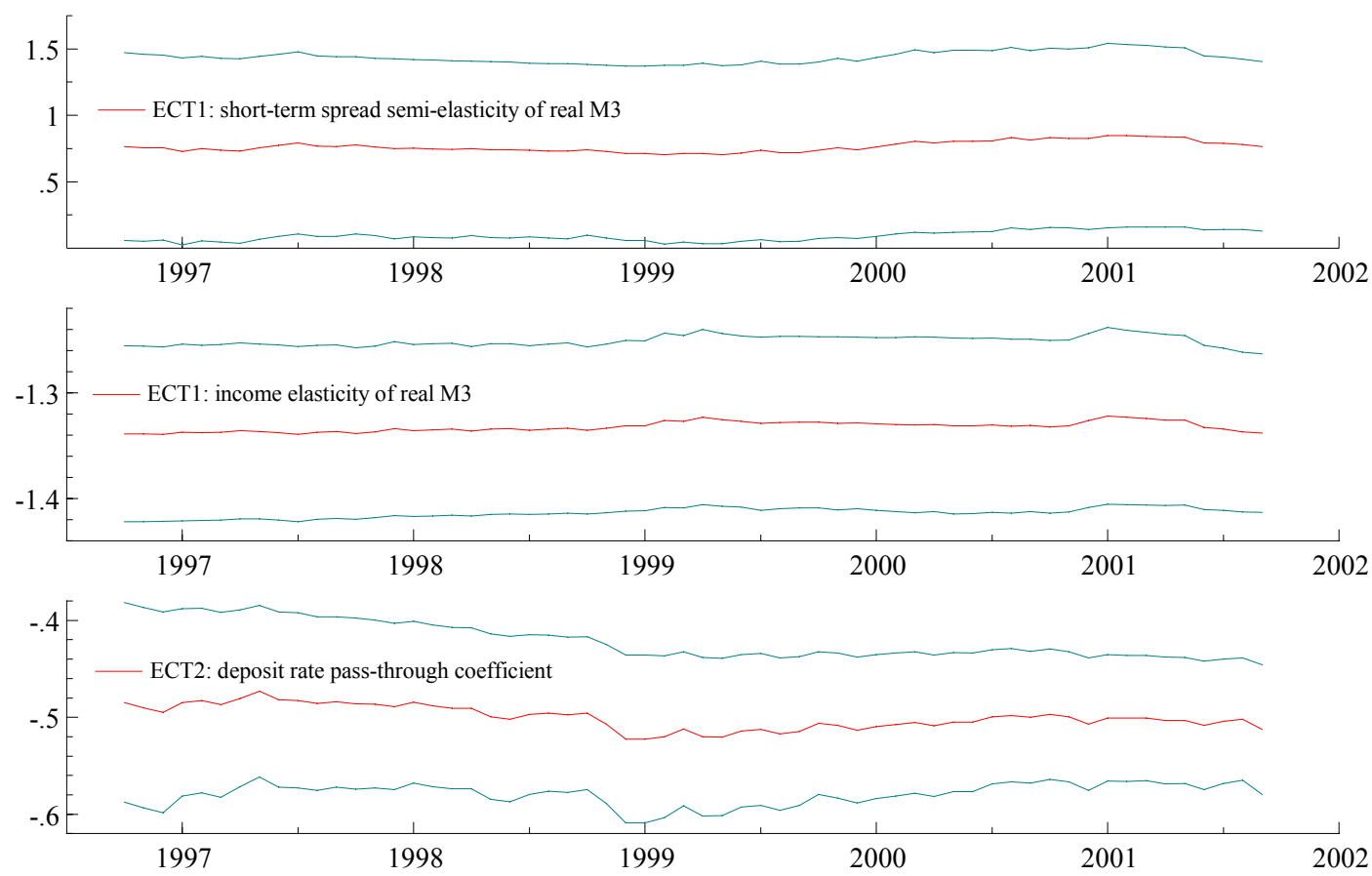


\subsection{Monthly Loan Demand Model}

The monthly loan demand model is estimated using the following five endogenous variables: real loans to the private sector (Rloans), the composite lending rate (CLR), HICP inflation $(\pi)$, the short-term market interest rate and real GDP. The inflation rate and the composite lending rate are included as separate variables in order to test whether the nominal or the real composite lending rate affects the real demand for loans. The loan demand model aims at the identification of a loan demand equation and a long-run pass-through between the monetary policy instrument and the composite lending rate, in line with the results found for the monthly money demand model $^{30}$. Consistently with the selection criteria applied for the money demand model, 7 lags are included in order to avoid autocorrelation in the system. One impulse dummy variable is added for January 1999 to correct for an outlier in Rloans. ${ }^{31}$ In addition, one exogenous variable is added: MA_cash. The real cash value of mergers and acquisitions and the UMTS licences is introduced to capture the considerable and unprecedented increase in the loans granted by euro area MFIs to the private sector at the end of the nineties, beginning of 2000 (see Chart AI. 5 and Chart AI. 6 in Appendix I). During the econometric modelling process, estimations of the loan demand model without this exogenous variable revealed high instability in the system. The increase in loan demand at the end of the sample was not sufficiently explained by the developments in the scale variable (real GDP) and the real cost of lending (real CLR $)^{32}$. As a result, the coefficients of the loan demand equation were estimated at extremely high and unstable values. Among several candidate additional explanatory variables $^{33}$, the cash value of mergers and acquisitions and of the UMTS licenses appeared to be the most correlated with the observed increase in loans. Indeed, a considerable part of the non-financial corporations' expenditures for mergers and acquisitions and for the UMTS licenses was financed by bank loans, which could

30 De Bondt, Mojon and Valla (2003) conclude that most retail bank lending rates are not only affected by the short-term market interest rate, but also by the long-term market interest rate. For reasons of parsimony, however, the long-term market interest rate is not included in this model.

31 The strong increase in loans to the private sector in January 1999 was mainly related to the new statistical reporting system entering into force on 1 January 1999.

32 This phenomenon could be referred to as the procyclicality of the bank credit supply according to which loans increase more than proportionally in business cycle expansions while the opposite holds in case of downturns. However, available empirical evidence for the US indicates that the procyclical effects are rather small; hence they could not explain fully the present situation. See among others: Berger, Kyle and Scalise (2001) and Berger and Udell (2003).

33 During the estimation process, other variables have been considered: different dummies of various designs, the number of mergers and acquisitions, and direct investment of the euro area 
explain, at least partly, the pattern observed in loans to the private sector. Regarding the deterministic component, the choice made for the money demand model is maintained here so that the specification allows for a linear trend in the data.

Johansen's trace test statistics for the loan demand model are presented in Table AIII. 1 in Appendix III. For the same reasons as mentioned earlier the test statistics are not comparable to any of the critical values in the table ${ }^{34}$. Whereas the critical values corrected for the exogenous variable can be seen as the upper boundary, the lower boundary is more difficult to identify. Notwithstanding this, the absence of cointegration cannot be rejected on the basis of the trace test statistic. This statistical result is however rather puzzling. First, both theoretical expectations and previous empirical studies on loan demand and on the pass-through from short-term market interest rates to retail bank lending rates in the euro area suggest the existence of two cointegrating vectors. Second, preliminary investigations in smaller sub-systems of the one used here also indicate the existence of two long-run relationships ${ }^{35}$. Following the principle of "specific to general",36 (Juselius (1993), Juselius and MacDonald (2000)), it is always possible to at least replicate the results of a smaller system when expanding the information set. "Because the cointegration property is invariant to extensions of the information set such a procedure is likely to facilitate the identification of cointegration relations without loss of information. If cointegration is found within a smaller set of variables, the same cointegration relations will be found in an extended set" ${ }^{\prime 37}$. Therefore, it is further assumed that the

corporations in the US. Alternatively, we also tried to filter the loans series for its share due to mergers and acquisitions and UMTS financing.

34 The inclusion of an exogenous variable in a cointegrated system increases the critical values of the trace test. See among others: Johansen and Nielsen (1993), Harbo, Johansen, Nielsen and Rahbek (1998), Rahbek and Mosconi (1999), Pesaran, Shin and Smith (2000). At the same time, the inclusion of the dummy variables would result in lower critical values.

35 When a first sub-system including Rloans, CLR, GDP and inflation is estimated over the sample period January 1981 - December 1997 the trace test suggests the existence of one cointegrating vector that can be identified as Rloans $=c_{2}+1.46 * G D P-0.90 *(C L R-\pi)+\varepsilon$. This is not significantly different from what we find in the loans model, except for the fact that we included the real cash value of mergers and acquisitions as an exogenous variable in the system to capture the very strong increase in real loans growth in the period 1998-2000 which resulted in instability in the loan demand equation. In a second sub-system including CLR, IRS and inflation the trace test suggests the existence of another cointegrating vector, which can be identified as a long-run pass-through equation $C L R=c_{1}+0.72 * I R S+\varepsilon$ which is again not significantly different from what we find in the loans model.

36 For a discussion of the advantages of the "specific to general" versus "general to specific" approach in the choice of the variables, see Juselius (1993) p. 607. Juselius argues that one can first model smaller sub-systems and then combine these results into an encompassing model. Juselius and MacDonald (2000), p. 15. 
loan demand system contains two cointegrating vectors, a choice which will turn out to be supported by the parameter estimates of both the long-run relations and the main adjustment coefficients, by the stability analysis of the cointegrating vectors and by the recursive likelihood ratio test. The identified vectors and the adjustment speeds are presented in Table 3 and Table 4 respectively.

Table 3: The cointegrating vectors of the loan demand model

\begin{tabular}{lcccccc}
\hline & Rloans & CLR & IRS & $\pi$ & GDP & MA_cash \\
\hline ECT 1 & 1 & 1.476 & 0 & -1.476 & -1.430 & -0.006 \\
& & {$[0.399]$} & & & {$[0.040]$} & {$[0.001]$} \\
ECT 2 & 0 & 1 & -0.694 & 0 & 0 & 0 \\
& & & {$[0.037]$} & & & \\
\hline
\end{tabular}

Note: Standard errors are between brackets.

Table 4: The adjustment speeds of the loan demand model

\begin{tabular}{lcc}
\hline & ECT1 & ECT 2 \\
\hline Rloans & -0.039 & -0.084 \\
\multirow{2}{*}{ CLR } & {$[0.011]$} & {$[0.052]$} \\
\multirow{2}{*}{ IRS } & -0.012 & -0.064 \\
& {$[0.005]$} & {$[0.022]$} \\
$\pi$ & -0.022 & 0 \\
& {$[0.011]$} & \\
GDP & 0 & -0.067 \\
\hline & 0 & {$[0.044]$} \\
rote: Standard errors are between brackets.
\end{tabular}

The set of restrictions imposed on the system is not rejected by the data ${ }^{38}$ and the two vectors, such as they are identified, can be interpreted as a loan demand and a passthrough equation respectively whose parameters are broadly stable over time. The specification including two cointegrating vectors seems therefore appropriate.

The first cointegrating vector is identified as a long-run demand for loans equation, where loan demand depends positively on the scale variable, real GDP, and negatively

38 With a P-value of 0.0448 these restrictions are actually rejected for the very last period of the recursive analysis, albeit only marginally (see Chart AIII. 2 in Appendix III). This is not the case when the adjustment coefficient of real GDP to the ECT1 would not be restricted to zero, i.e. when real GDP would no longer be weakly exogenous. In that case the P-value of the restrictions would amount to 0.0948 . However, this additional zero restriction is only rejected for the full sample ending in September 2001, and even then only at the 5\% significance level. Given the exceptional situation after the September 11 attacks on the US and the results of previous studies on loan demand in the euro area and in line with the results for the encompassing monetary model, the zero restriction is therefore retained in the further analysis. 
on the real cost of bank lending (the spread between the composite lending rate and inflation):

$$
\text { Rloans }=c_{3}+1.430 * G D P-1.476 *(C L R-\pi)+0.006 * M A \_c a s h+\varepsilon
$$

The inclusion of the inflation rate as an additional endogenous variable in the system permits to test the hypothesis of homogeneity between the nominal composite lending rate and the inflation rate. This would be in line with decisions on fixed capital formation and housing investment being based on real interest rates instead of on nominal ones. As expected, this hypothesis is not rejected by the data. The coefficient of the exogenous variable, the real cash value of mergers and acquisitions and the UMTS licences, is positive and highly significant. In terms of stability, however, the recursive estimates of this last coefficient show a somewhat higher value for the period 1999-2000 when the wave of mergers and acquisitions peaked (see Chart 2). In addition, the recursive estimates of the income elasticity and of the real composite lending rate semi-elasticity show a slight upward trend towards the end of the sample. Most probably, the inclusion of the exogenous variable does not fully account for the increase in the loan demand; hence, the two former coefficients are estimated at a slightly higher level (in absolute value) towards the end of the sample ${ }^{39}$.

The second cointegrating vector has the same interpretation as its corresponding vector in the money demand model. This is the long-run pass-through between the monetary policy instrument and the retail bank lending rates:

$$
C L R=c_{4}+0.694 * I R S+\varepsilon
$$

It is worth noticing that the coefficient is significantly higher than for the deposit rates. This is in line with the findings of the pass-through literature that the long-run effects on the lending rates are on average more important than on most of the deposit rates due to a tougher competition in the lending segments of the retail bank market ${ }^{40}$.

39 This could be related to the strong increase in house prices in some euro area countries. Due to a lack of high-quality data, this hypothesis could however not be tested. Calculations based on annual non-harmonised national data suggest that the annual growth rate of house prices in the euro area countries indeed increased considerably in the period 1998-2000, although for the euro area as a whole the rise was not exceptional compared with the developments in 1986-89.

40 The main exception is the long-run pass-through of the retail bank rates on time deposits, which is generally found to be very high, in line with the high degree of competition in this segment of the retail bank deposit market (see e.g. de Bondt (2000)). 


\section{Chart 2: Recursive estimates of the long-run coefficients $(+/-2 *$ standard error)}
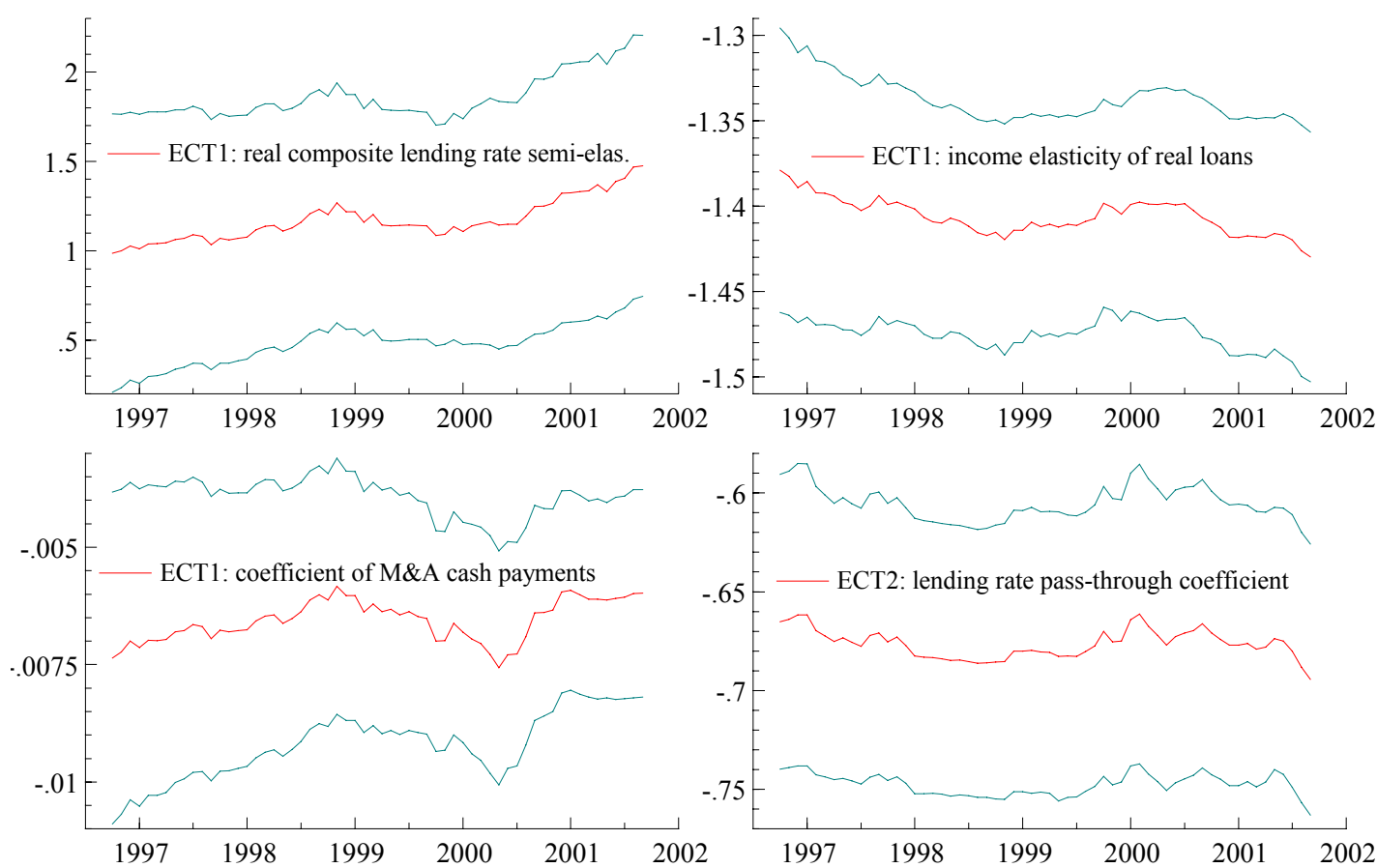

At the same time, our estimate is significantly lower than the estimates for individual types of loans presented in de Bondt (2002) for the period 1996-2001. Also the incomplete pass-through to the retail bank lending rates can be partly explained by the existence of menu costs for the banks, the existence of switching costs for the borrowers and the uncertainty about the future developments in the short-term market interest rate. In addition, also the maturity structure of loans can partly explain why changes in the short-term market interest rate that are not accompanied by similar changes in the long-term market interest rates are not fully transmitted to the synthetic retail bank lending rate.

Regarding the adjustment speeds with respect to the first cointegrating vector, real loan demand, the composite lending rate and the short-term market interest rate react to a disequilibrium in the long-run loan demand ${ }^{41}$. While the own rate of M3 did not react to a disequilibrium in the long-run demand for money, the composite lending rate seems to react within the next month to a disequilibrium in the demand for loans. This could probably be explained by the stronger link between the composite lending

41 Note that the sign of the coefficients of the interest rates is opposite to the one expected. This is also observed in Calza, Gartner and Sousa (2003) and in Calza, Manrique and Sousa (2003), although in the latter the coefficient is not statistically different from zero. 
rate and the short-term market interest rate, according to the second vector, since both adjust in the same direction. It could be an indication of a more competitive environment on the credit market. Regarding the adjustment speeds with respect to the second cointegrating vector, the short-run pass-through of the composite lending rate turns out to be larger than the equivalent measure for the deposit rate. This confirms again the existing evidence from the pass-through literature. Contrary to the results in the money demand model, also real loans will react to a deviation of the CLR from its long-run value. Although the coefficient is only borderline significant, this could be seen as indicating that the reaction of the demand for loans to the cost of lending is stronger than the reaction of the demand for money to the opportunity costs. This is also in line with the fact that the estimated long-run real lending rate semi-elasticity is larger (in absolute value) than the long-run opportunity costs semi-elasticity. Finally, similarly to the money demand model, real GDP is tested and verified as being weakly exogenous.

\subsection{Monthly Encompassing Monetary Model}

The final step in this cointegration analysis is to encapsulate the monthly money demand and the monthly loan demand models into one encompassing monthly monetary model. The encompassing model includes the seven endogenous variables, the exogenous variable and the four dummies used previously. The specification of the deterministic term remains the same. The number of lags equals 6, which eliminates any autocorrelation in the system.

Johansen's trace test statistics are reported in Table AIV. 1 in Appendix IV. The absence of appropriate critical values corrected for dummies and exogenous variables makes the choice of the cointegration rank again somewhat arbitrary. However, taking into account that the inclusion of dummy variables lowers the critical values corrected for the inclusion of an exogenous variable, a cointegration rank of 4 does not seem unlikely. In addition, the test statistics for the system excluding the dummies and the exogenous variables leads to the same conclusion. Finally, the "specific to general" principle applied to the combination of the money demand and the loan demand systems also suggests a rank of (at least) 4. Against this background a rank of 4 is chosen. 
The coefficients of the four identified cointegrating vectors and their adjustment speeds are presented in Table 5 and Table 6 respectively. The cointegration vectors and the recursive LR test are reported in Appendix IV in Chart AIV. 1 and Chart AIV. 2 respectively.

Table 5: The cointegrating vectors of the encompassing monetary model

\begin{tabular}{|c|c|c|c|c|c|c|c|c|}
\hline & Rmoney & Rloans & MOR & CLR & IRS & $\pi$ & GDP & MA_cash \\
\hline ECT 1 & 1 & 0 & $\begin{array}{l}-0.935 \\
{[0.289]}\end{array}$ & 0 & 0.935 & 0 & $\begin{array}{l}-1.295 \\
{[0.031]}\end{array}$ & 0 \\
\hline ECT 2 & 0 & 1 & 0 & $\begin{array}{l}2.940 \\
{[0.463]}\end{array}$ & 0 & -2.940 & $\begin{array}{l}-1.401 \\
{[0.049]}\end{array}$ & $\begin{array}{l}-0.006 \\
{[0.001]}\end{array}$ \\
\hline ECT 3 & 0 & 0 & 1 & 0 & $\begin{array}{l}-0.599 \\
{[0.056]}\end{array}$ & $\begin{array}{c}0.339 \\
{[0.060]}\end{array}$ & 0 & 0 \\
\hline ECT 4 & 0 & 0 & -1 & 1 & $\begin{array}{l}-0.205 \\
{[0.037]} \\
\end{array}$ & 0 & 0 & 0 \\
\hline
\end{tabular}

Note: Standard errors are between brackets.

Table 6: The adjustment speeds of the encompassing monetary model

\begin{tabular}{|c|c|c|c|c|}
\hline & ECT 1 & ECT 2 & ECT 3 & ECT 4 \\
\hline Rmoney & $\begin{array}{l}-0.060 \\
{[0.015]}\end{array}$ & 0 & 0 & 0 \\
\hline Rloans & $\begin{array}{l}-0.029 \\
{[0.014]}\end{array}$ & $\begin{array}{l}-0.032 \\
{[0.008]}\end{array}$ & 0 & $\begin{array}{l}-0.109 \\
{[0.040]}\end{array}$ \\
\hline MOR & 0 & 0 & $\begin{array}{l}-0.036 \\
{[0.014]}\end{array}$ & $\begin{array}{c}0.039 \\
{[0.010]}\end{array}$ \\
\hline CLR & 0 & $\begin{array}{c}-0.008 \\
{[0.004]}\end{array}$ & 0 & $\begin{array}{l}-0.056 \\
{[0.018]}\end{array}$ \\
\hline IRS & $\begin{array}{l}-0.031 \\
{[0.010]}\end{array}$ & 0 & 0 & 0 \\
\hline$\pi$ & $\begin{array}{c}0.028 \\
{[0.011]}\end{array}$ & 0 & $\begin{array}{l}-0.160 \\
{[0.044]}\end{array}$ & 0 \\
\hline GDP & 0 & 0 & 0 & 0 \\
\hline
\end{tabular}

The first cointegrating vector is the long-run money demand, which is not significantly different from the one estimated in Section 3.1 (see equation (2)):

Rmoney $=c_{5}+1.295 * G D P-0.935 *(I R S-M O R)+\varepsilon$

The second cointegrating vector represents the new long-run loan demand:

Rloans $=c_{6}+1.401 * G D P-2.940 *(C L R-\pi)+0.006 * M A \_$cash $+\varepsilon$

Compared with the results in equation (4) the estimate of the real composite lending rate semi-elasticity is now significantly higher (in absolute value), but it is still 
significantly smaller than the estimate reported in Calza, Manrique and Sousa $(2003)^{42}$.

The third cointegrating vector is the long-run pass-through from the short-term market interest rate to the synthetic deposit rate, which now also includes inflation:

$M O R=c_{7}+0.599 * I R S-0.339 * \pi+\varepsilon$

This new long-run pass-through equation suggests that the deposit rates depend positively on the short-term market interest rate, but also negatively on inflation. The interpretation of the latter is not straightforward. One possible explanation could be that this long-run pass-through equation suffers from an omitted variable problem, as also longer-term market interest rates can be expected to affect the deposit rate (on e.g. deposits with an agreed maturity between three months and two years). In that case the omission of the long-term market interest rate from the system would result in an upward bias of the coefficient of the short-term market interest rate (which would then also capture the impact of the long-term market interest rate) and the coefficient of inflation could be seen as capturing the anticipations of the banking system concerning long-term inflation which they would not pass on to the shorterterm deposit rates. Another explanation could be that the impact of the short-term market interest rate and of the inflation rate could not be distinguished properly in the system, given that they behaved very similar over the sample period considered.

Finally, the fourth cointegrating vector identifies the link between the intermediation margin of the banking sector and the short-term market interest rate and replaces the former long-run lending rate pass-through present in the loan demand model:

$$
C L R-M O R=c_{8}+0.205 * I R S+\varepsilon
$$

Equation (9) boils down to a linear combination of equations (3) and (5), which could not be identified in the loan demand model. Two interpretations are possible. First, the positive relationship between the positive intermediation margin ${ }^{43}$ and the short-term market interest rate could be expected, given the fact that the long-run pass-through coefficient for the lending rate was significantly larger than the one for the deposit rate. In this interpretation the variable linking the two synthetic retail bank interest rates is the short-term interest rate. Second, this equation might indicate that, in the long run, banks take their deposit rates into account when deciding on their lending

42 Their identification does not include the variable correcting for mergers and acquisitions and the UMTS licences.

43 The constant is estimated positive. 
rates, suggesting that they use deposits as a marginal buffer to finance their loans. This would imply that the assumption of separability of bank deposit and bank lending rates in the Monti-Klein model is not supported by the data. Since the additional restriction that the deposit rate does not enter the long-run lending rate pass-through is rejected by the data, the second interpretation seems to be more likely.

We now turn to the description of the system's adjustment coefficients. Concerning the adjustments following a disequilibrium in long-run real money demand, two new facts are noteworthy. First, inflation, which was not included in the money demand model, reacts positively to a deviation of the long-run money demand equation. Hence, inflation increases following an excessive money demand. Second, there is a link between money and loans, although it is not very significant. Both money and loans react negatively to a deviation of money from its long-run equilibrium. For instance, after an excessive money demand, M3 growth will decrease to bring money demand back to its equilibrium and also loan growth would be lower. This reaction of loan demand may be interpreted as a manifestation of the bank-lending channel where the fall in the deposits induces an accompanying fall in the loan supply, thereby depressing the loan demand. Besides these two remarks, one can also notice that the reaction of money to its own disequilibrium is somewhat larger than in the money demand model, although the difference is not statistically significant.

As far as the second cointegrating vector is concerned, the major change as compared with the loan demand model is that the short-term market interest rate is no longer reacting to a disequilibrium in loan demand. The only variables that react to such a disequilibrium are real loans and the composite lending rate.

The dynamic properties of the own rate of M3 with respect to the third error correction term remain unchanged. However, in this encompassing monetary model also inflation reacts negatively to a positive deviation of the own rate of M3 from its long-run level.

Finally, the own rate of M3, the composite lending rate and real loan demand react to a deviation of the intermediation margin from its long-run equilibrium. If the margin is too large, the MOR will rise and the CLR and the loans will decrease. The reaction of the loan demand is very similar to the one observed in the loan demand model after a disequilibrium in the CLR pass-through. It is also worth noting that the adjustment speed of the composite lending rate is higher than for the deposit rate. This confirms 
again that lending rates are less sticky in their adjustments. This is possibly due to the higher competition ruling the lending market.

While the analysis of the adjustment speeds only gives a partial picture of the full dynamics in the system - which will be analysed in the next section - some preliminary conclusions can already be drawn at this stage of the analysis. First, the second cointegrating vector seems to be much less important for the short-run dynamics than the first cointegrating vector, as indicated by the fact that the second cointegrating vector triggers a reaction of fewer endogenous variables in the system than the first one. This could be seen as an indication of the existence of a bank lending channel, in that disequilibria in money demand are followed by reactions in most of the variables in the system, including real loans to the private sector. Second, the results suggest that the dynamic links between the retail bank interest rates are rather complex, in that the retail bank deposit rate reacts to disequilibria in both the deposit rate pass-through and the intermediation margin, while the retail bank lending rate only reacts to the latter.

To conclude this section, we briefly discuss the stability properties of the cointegrating vectors and the recursive estimates of the LR test. Chart AIV. 2 in Appendix IV shows that the system, as identified in Table 5 and Table 6 , is not rejected by the data. Hence, the encompassing monetary model provides a fairly good representation of actual developments over the sample period considered. Overall, the stability of the coefficients is broadly satisfying, although the parameters of the loan demand equation show a lot of instability in the period 1998-2000 (see Chart 3). The correction for the mergers and acquisitions included in order to stabilise the loan relation in the late nineties and the beginning of 2000, is clearly not sufficient in this model. While the variable MA_cash proved to smooth the estimations in the loan demand model, once money and loans are estimated together the smoothing effect is much smaller. 
Chart 3: Recursive estimates of the long-run coefficients (+/- $2 *$ standard error)
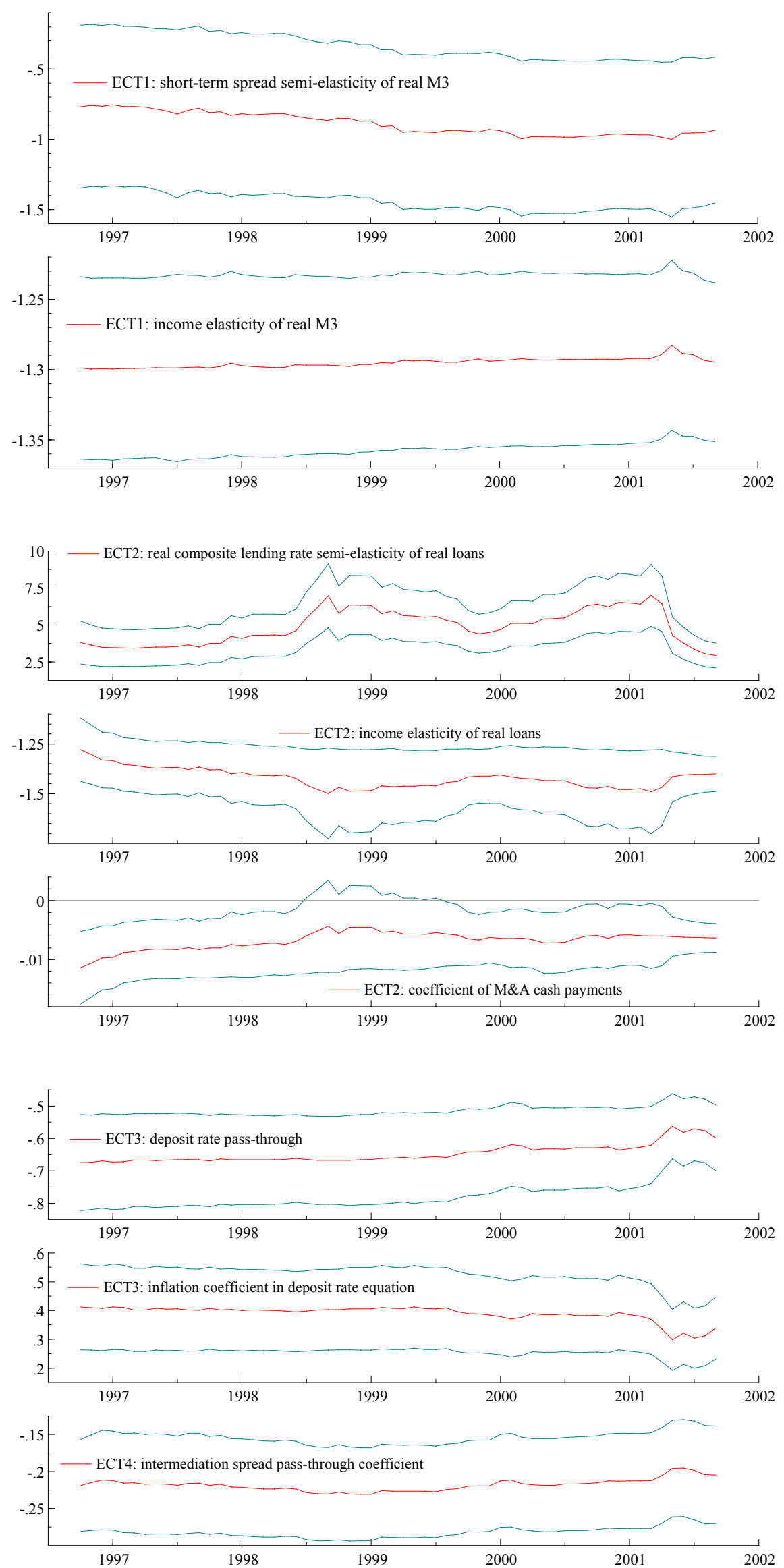
This suggests that the instability could be due to a possible change in the link between money and loans. In general, one would expect the growth rates of M3 and loans to develop in parallel since both are mainly driven by the scale variable GDP. While this has indeed been the case over most of the sample period considered in this study, this pattern broke down in the late 1990s (see Chart AI. 3 to Chart AI. 5 in Appendix I). A first explanation could be that the temporary wave of mergers and acquisitions resulted in a very strong demand for loans which created tensions in the lending market and distorted the link between money and loans. In banks' balance sheet terms, the huge outflow of funds from the euro area resulted in a steep decline in the net external assets of the euro area banking sector, which distorted the link between M3 and its main counterpart, namely loans to the private sector. While the strong mergers and acquisitions activity can explain part of these developments, also euro area residents' portfolio investment abroad financed by bank loans could have contributed to this. Obviously, also recent developments taking place in the financial markets may explain part of the uncoupling of the developments in M3 and loans, as they have modified the portfolio behaviour of investors and thus their demand for monetary assets. Against a background of sustained declines in stock prices and the increase in stock market volatility at the end of our sample, euro area investors have demonstrated a pronounced preference for safe and liquid assets, such as the instruments included in M3. This has resulted in a strong increase in M3 growth that was not accompanied by a similarly strong increase in loan growth.

In order to test whether the link between money and loans has indeed changed in the late 1990s, the coefficient of adjustment of the loan demand for a deviation in ECT1 is set to zero. As a result, the recursive estimates of the parameters of the loan demand equation become indeed more stable. The drawback of this additional restriction is however a worsening of the fit of the whole model as tested by the likelihood ratio test. The alternative model tends to be rejected over a substantial part of the sample, in particular for the period of the mergers and acquisitions wave. If one considers this uncoupling of the developments in M3 and loans as a temporary phenomenon, the model presented in the paper is to be preferred over this alternative one, even though its coefficients may be somewhat more unstable between mid-1998 and mid-2001. 


\section{A monthly monetary model with banking intermediation for the euro area: a dynamic analysis}

As already mentioned above, the analysis of the adjustment speeds gives only a partial picture of the full dynamics of the system. This section is therefore dedicated to the discussion of the impulse response functions (IRFs) and the forecast error variance decompositions (FEVDs) of the encompassing monetary model that encapsulates the two smaller models. As it will appear below, the shocks identified in the encompassing model are recovered in the two smaller ones, the results of which are presented in Appendix VII and Appendix VIII respectively. Before discussing in detail the different shocks, we briefly remind of the identification problem encountered in S-VAR and S-VEC models, as well as the different techniques developed to tackle it ${ }^{44}$.

One interesting property of the VAR and VEC methods is the possibility to simulate uncorrelated/structural shocks and plot the reactions, also called impulse response functions, of all endogenous variables in the system. This tool is frequently called upon to assess the impact of shocks on the economy. There is, for instance, a broad body of literature discussing the divergences or similarities in the impact of those shocks across countries.

However, the use of this convenient tool requires the setting of restrictions on the variance-covariance matrix of the residuals of the reduced form model; in other words, the shocks must be orthogonalised. The need for those restrictions originates from the different number of coefficients in the primitive system of the S-VAR model and in the standard representation of the reduced form model. In practice, the number of coefficients estimated by means of the reduced form model is smaller than the number of coefficients in the genuine structural model. Hence, it is impossible to recover all the information present in the structural system from the estimated reduced-form model. One way to overcome this problem and to identify the structural shocks is to impose restrictions on the available information, i.e. on the variancecovariance matrix of the residuals of the reduced model where the instantaneous relationships between the variables are hidden.

44 For a very clear exposition of the identification of the IRFs in an S-VAR model, see Enders (1995) and Amisano and Giannini (1997). 
Among the different techniques of orthogonalisation of the shocks, the most common one is certainly the Cholesky decomposition, as originally proposed by Sims (1980). The main criticism addressed to this technique is the recursive structure that is imposed by assumption. As a result, the ordering of the variables is determining the dynamics of the system and the pattern of the IRFs. An alternative is the BlanchardQuah (1989) identification scheme. Instead of using an arbitrary statistical tool, Blanchard and Quah suggest to rely on economic theory to impose the restrictions. Keeping in mind their concern for economic intuition, they distinguish between shortterm and long-term shocks as well as between the contemporaneous and the lagged impact of the shocks. In this way, it is possible to disentangle shocks having a longrun impact (e.g. a productivity or aggregate supply shock) from shocks that will die out after a period of time (typically an aggregate demand shock). Similarly, one can distinguish shocks having a contemporaneous impact on the variables (e.g. an interest rate shock on money demand) from shocks having a lagged impact only (e.g. the same interest rate shock on the retail bank interest rates). Vlaar (1998) generalises the method of Blanchard and Quah for a cointegrated system ${ }^{45}$. Two kinds of restrictions can be imposed on the S-VECM: restrictions on the long-run effects and restrictions on the contemporaneous impact of the innovations. Extending the work of King, Plosser, Stock and Watson (1991) and Stock and Watson (1988) on the common trends, Warne (1993) develops a very similar framework. He suggests identifying permanent and transitory shocks, where the permanent shocks are mutually identified by imposing restrictions on some of the long-run impacts, while the transitory shocks are mutually identified by means of the restrictions on their contemporaneous impact $^{46}$.

45 Note that the transposition of the result of Blanchard and Quah in a cointegrated system is not straightforward. The existence of cointegrating vectors, changes the number of restrictions needed to identify the innovations. It also affects the asymptotic distribution of the confidence bounds of the impulse response functions.

46 There is a minor difference between the method of Vlaar (1998) and Warne (1993). Vlaar allows for both contemporaneous and long-run restrictions on the permanent shocks to mutually identify them, while Warne allows only for the second type of restrictions. For a similar approach see also Dhar, Pain and Thomas (2000). 
In this paper, the latter method is used and the simulations are performed with MALCOLM that contains the routine for the common trends identification ${ }^{47}$. In this context the number of permanent shocks is determined as the difference between the total number of endogenous variables and the number of cointegrating vectors. Therefore, in the encompassing monetary model, three permanent and four temporary shocks should be identified ${ }^{48}$. Three linearly independent restrictions on the permanent innovations and six on the temporary innovations are sufficient to orthogonalise the shocks and exactly identify the system ${ }^{49}$. Several over-identifying restrictions are rejected (see below). However, most probably the rejection of the over-identifying restrictions results partly from the difficulty to properly test for them. Indeed, in view of the non-normality of the residuals of the reduced VECM, it is not appropriate to rely on the likelihood ratio test for the rejection of over-identifying restrictions. The identified shocks are actually combinations of one standard error innovations (contained in the residuals) in the different endogenous variables and are labelled with a name depending on the pattern of the resulting impulse response functions. Throughout the discussion the short-term market interest rate is interpreted as the monetary policy instrument, which provides an interpretation of the reaction of the monetary authorities.

The restrictions imposed on the encompassing monetary model are based on economic theory and on existing evidence in the relevant literature. Hence, in line with e.g. Coenen and Vega (1999) and Hubrich and Vlaar (2003) the aggregate supply shock is assumed to have no long-run impact on inflation ${ }^{50}$. The long-run nominal shock or inflation objective shock is assumed not to have a long-run impact on real GDP and real loans, which at least for the impact on real GDP is in line with Coenen and Vega (1999) and Cassola and Morana (2002). Finally, following Hubrich and Vlaar (2003), the permanent structural shock or institutional shock is not restricted at all. The four temporary shocks are mutually identified by the following restrictions. The money demand shock is assumed to have no contemporaneous impact on the composite lending rate. The loan demand shock is the mirror image of the

47 MALCOLM, running on RATS, version April 2002.

48 As far as the monthly money demand model and the monthly loan demand model are concerned, we have, respectively, two permanent and two temporary; and three permanent and two temporary shocks.

49 Consistently with the approach of Warne, we do not resort to contemporaneous restrictions to mutually identify the permanent shocks.

50 Cassola and Morana (2002) do not impose this restriction, but they also find that a productivity shock has no long-run impact on inflation. 
money demand shock: the own rate of M3 is assumed not to react contemporaneously to this type of shock. The banking shock or intermediation margin shock is restricted not to have an immediate influence on inflation and, hence, not to lead to a simultaneous reaction of the monetary authorities through an adjustment of the shortterm market interest rate. Finally, the interest rate shock or monetary policy instrument shock does not lead to a contemporaneous adjustment of the composite lending rate and the own rate of M3. With those restrictions we impose a certain stickiness usually observed in the adjustment of retail bank interest rates. Concerning the restrictions on the contemporaneous impact of the shocks on GDP, an interesting feature is that all restrictions on GDP revealed non-binding restrictions. Actually, the restrictions are not linearly independent because of the zero restrictions imposed on the adjustment speeds in the cointegration analysis (where GDP was tested as being weakly exogenous).

This set of exactly-identifying restrictions can be summarised in the following matrices $^{51}$. The variables are ordered as follows (for each line): real GDP, inflation, real loans, the short-term market interest rate, real M3, the composite lending rate and the own rate of M3. The shocks are in columns, following the order used above in the paragraph. A 0 indicates the position of a zero restriction.

Long-run impact of permanent innovations: $\left[\begin{array}{ccc}1 & 0 & 1 \\ 0 & 1 & 1 \\ 1 & 0 & 1 \\ 1 & 1 & 1 \\ 1 & 1 & 1 \\ 1 & 1 & 1 \\ 1 & 1 & 1\end{array}\right]$

Contemporaneous impact of temporary innovations: $\left[\begin{array}{cccc}1 & 1 & 1 & 1 \\ 1 & 1 & 0 & 1 \\ 1 & 1 & 1 & 1 \\ 1 & 1 & 0 & 1 \\ 1 & 1 & 1 & 1 \\ 0 & 1 & 1 & 0 \\ 1 & 0 & 1 & 0\end{array}\right]$

51 Similar matrices for the monthly money demand and the monthly loan demand models can be found in Appendix VII and Appendix VIII respectively. 
Before we proceed with a more detailed discussion of the different shocks individually, we discuss an interesting dynamic property encountered in the three systems. Contrary to the results in Coenen and Vega (1999) and Cassola and Morana (2002), it appears to be impossible in our model to identify innovations having only either a real or a nominal impact in the long run. Hubrich and Vlaar (2003) encountered a similar problem, which they overcame by identifying the two permanent shocks as one traditional aggregate supply/technological shock and one institutional shock. The latter has an impact on both inflation and output in the long run. "As the positive correlation between output and inflation indicates important Phillips curve effects, this shock is probably related to all kinds of changes in the economy that affect the supply or demand of labour. Given the permanent impact, especially shocks that affect the structural unemployment rate, for instance due to labour rigidities, e.g. to the duration and coverage of unemployment benefit programs or to the increased demand for employment in the service sector, seem to matter here. On the labour supply side, one can for instance think of an increase in unemployment benefits relative to wages (the replacement rate) ${ }^{, 52}$.

The label of institutional shock is certainly relevant for one of the three permanent shocks or common trends in our model. However, there is another shock (labelled aggregate supply) that shows an unconventional pattern in terms of the IRF of the nominal interest rate variables. Although the long-run impact on inflation is zero (as a result of a restriction), the nominal interest rates seem positively correlated with the aggregate supply shock ${ }^{53}$. This could be due to the non-stationarity of the real interest rates within the sample (See Chart AI. 2 in Appendix I) in which case the impulse response functions of the nominal interest rates might be the outcome of another shock (stochastic trend) that is not identified separately. The non-stationarity of the real interest rates could be rationalised by the disinflation context characterising the euro area countries over the major part of the sample period considered. The steady convergence of the euro area countries in the 1990s has resulted in a decrease in inflation and a more than proportional fall in the nominal interest rates, which could be linked to a decline in the inflation risk premium.

52 Hubrich and Vlaar (2001), p. 15.

53 Imposing the over-identifying restriction of long-run neutrality for either the short-term market interest rate or the retail bank interest rates is fiercely rejected by the system. 
We now explore more in detail the dynamic properties of the system by means of the impulse response functions (IRFs) and the forecast error variance decompositions (FEVDs) (for the latter, see Chart AV. 1 in Appendix V).

\section{Real shock: aggregate supply shock}

As expected, a negative aggregate supply shock triggers an immediate drop in real output and a slight increase in inflation. Whereas the drop in the output level is permanent, the shock has no significant long-run impact on inflation (as had been imposed). By contrast, the shock results in a permanent decline in the nominal shortterm market interest rate, indicating a permanent decline in the real short-term market interest rate following a negative aggregate supply shock. As mentioned above, the impulse response function of the short-term market interest rate presents an unusual pattern for a permanent real shock which could be due to the occurrence of another shock that is not identified separately and could be linked to the non-stationarity of the real short-term market interest rate. Part of the decline in the nominal short-term market interest rate is almost instantaneously transmitted to the retail bank interest rates, although - as expected - the composite lending rate is adjusted somewhat quicker and stronger than the deposit rate. This is in line with our previous findings of the cointegration analysis. Real money holdings decline gradually over time in reaction to the negative aggregate supply shock. Whereas during the first year after the shock the decline in the opportunity costs partly compensates the effect of the decline in real output, the latter becomes more important over time. Finally, real loans increase somewhat, although the effect becomes very quickly statistically insignificant. ${ }^{54}$ Also the different reaction patterns of real loans and real M3 are in line with the evidence of a larger decline in the real composite lending rate than in the opportunity costs of holding M3 and of a larger interest rate semi-elasticity and a lower income elasticity of the demand for loans than of the demand for money which derived from our cointegration analysis in the previous section.

54 Unlike in the encompassing monetary model, in the long run, real loans even return to the baseline in the smaller loan demand model. 
Chart 4: The impulse response functions to the aggregate supply shock
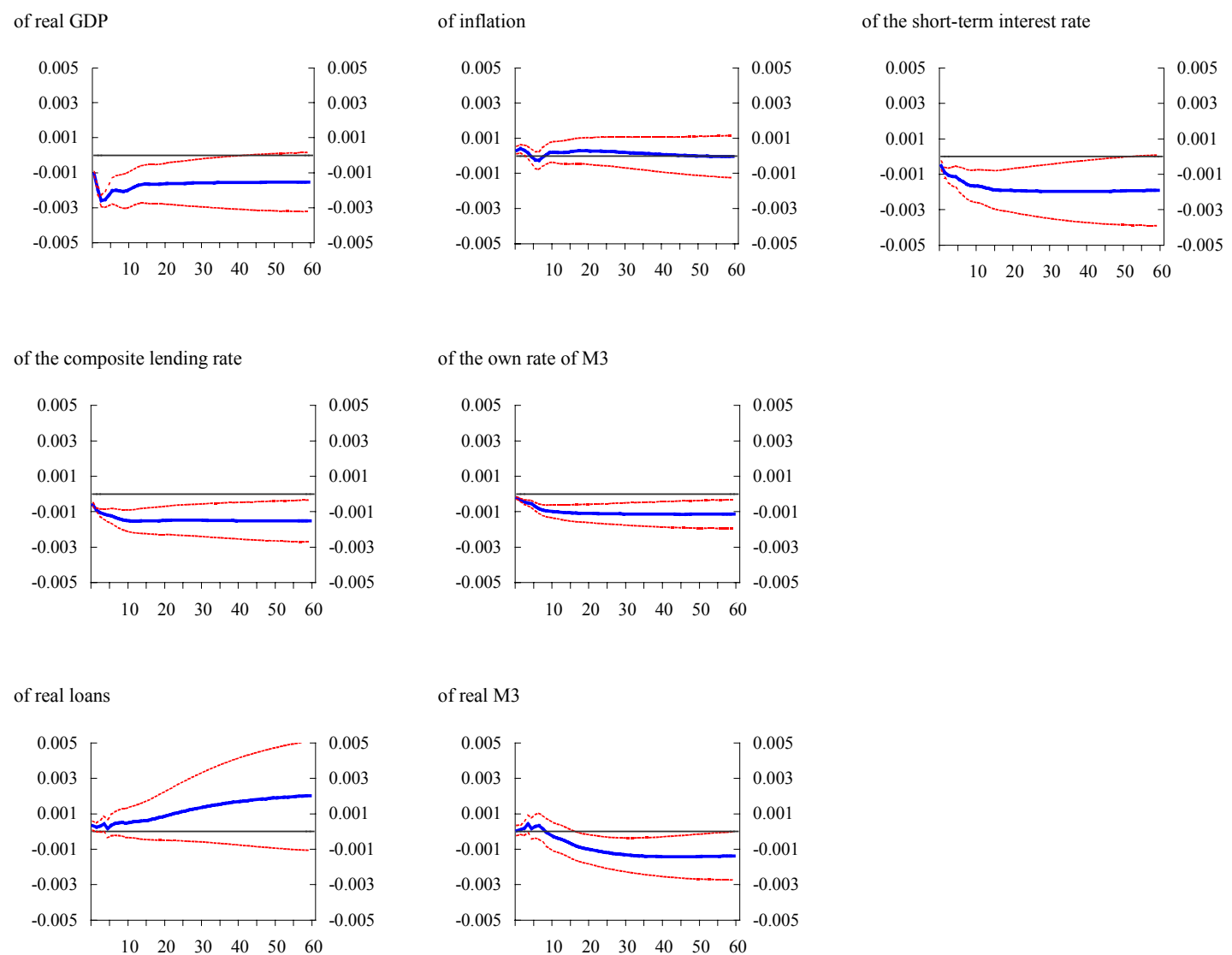

In terms of the FEVDs, this permanent aggregate supply shock accounts for a significant part of the shorter-term and long-term variability in real GDP and of the longer-term variability of the retail bank interest rates.

\section{Nominal shock: inflation objective shock}

The second permanent shock captures the nominal stochastic trend in the sample considered, which - in line with e.g. Coenen and Vega (1999) - could be interpreted as a pre-announced commitment to lower inflation ${ }^{55}$. A credible change in the inflation objective modifies permanently the inflation expectations and the inflation rate itself. As shown in Chart 5, a negative inflation objective shock results in a decline in inflation, but has no significant impact on real output, suggesting a low cost of disinflation. ${ }^{56}$ The fall in inflation is however smaller than the decline in the

55 Given that during most of the sample period there did not exist a common monetary authority, this shock can also be seen as describing the general process of declining inflation in the euro area countries during most of the sample period.

56 Only in the smaller money demand model does real GDP decline somewhat in the short run (see Appendix VII). 
nominal short-term market interest rate resulting in a decline in the real short-term market interest rate, which points again to the non-stationary nature of the latter possibly related to the decline in the inflation risk premium. The decline in the shortterm market interest rate is partly transmitted to both retail bank interest rates, confirming the expectations in terms of stickiness of the latter. Given that both real output and the real composite lending rate are hardly affected by the negative inflation objective shock, it is not surprising that also real loan demand is not significantly affected. At the same time, real money holdings do increase, in line with the decline in their opportunity costs.

\section{Chart 5: The impulse response functions to the inflation objective shock}
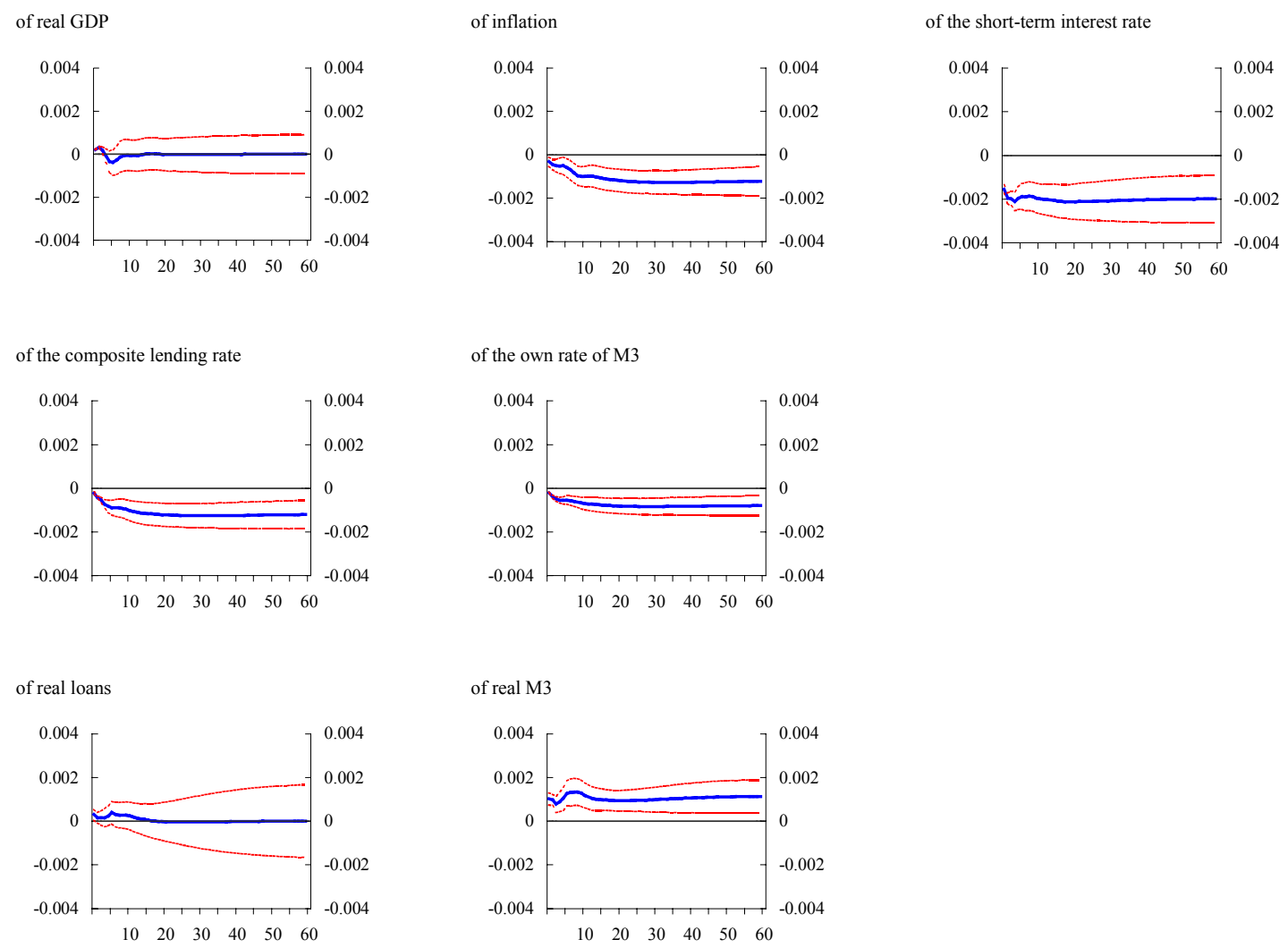

The well-known puzzle of the long-run non-neutrality of real money is thus also present in this model. According to the theoretical rationales, the real demand for money should be neutral in the long run to any nominal shock. An interesting result within our framework is that this puzzle can be solved by changing the specification of the money demand equation in the cointegration analysis. If real money demand depends exclusively on the scale variable, real GDP, the long-run neutrality of money 
is recovered. Obviously, this raises the controversial issue of the long-run link between money and interest rates. First, there is no consensus regarding which interest rates to use for capturing the opportunity costs of holding money. Second, the interest rate (semi-) elasticities are often imprecisely estimated. Cassola and Morana (2002) e.g. find that restricting the interest rate semi-elasticities in the money demand equation to zero is not rejected by the data.

As expected, this permanent nominal shock explains a significant part of the longerterm variability of inflation, but also of the retail bank interest rates and of the shorterterm variability of the monetary policy instrument and to a lesser extent of real M3.

\section{Institutional shock}

The effects of the third permanent shock are similar to those of the institutional shock found by Hubrich and Vlaar (2003) which they relate to the structural changes in the economy that affect the supply or demand of labour. One possible interpretation of such a shock could e.g. be a structurally higher demand for labour in some sectors of the economy that will result in higher real output, but also in higher wages and inflation. Another possible interpretation could be related to the gradual integration of product markets among the euro area countries giving rise to a Balassa-Samuelson effect. ${ }^{57}$ The gradual integration of product markets has probably induced productivity and wage increases in the tradable goods sectors of the so-called 'catching-up' countries. These wage increases will then partly translate into higher wages in the non-tradable goods sectors, which is expected to give rise to higher inflation, since the productivity in these sectors did not necessarily increase.

As expected, the increase in inflation is followed by a rise in the short-term market interest rate and subsequently in the retail bank interest rates. Notwithstanding the increase in the opportunity costs of holding money, real money holdings expand in line with the strong positive reaction of real GDP. A similar pattern is found for the demand for real loans, where the fuelling impact of higher real output is strengthened further by the impact of the small decline in the real composite lending rate. Again, the IRFs of the retail bank interest rates, real M3 and real loans are in line with the results of the cointegration analysis presented in the previous section.

57 A number of recent studies have found that the Balassa-Samuelson effect would imply steady state inflation differentials in the euro area countries, although the estimates are surrounded by a relatively large degree of uncertainty. For a discussion of these estimates, see e.g. Kieler (2003). 
Chart 6: The impulse response functions to the institutional shock
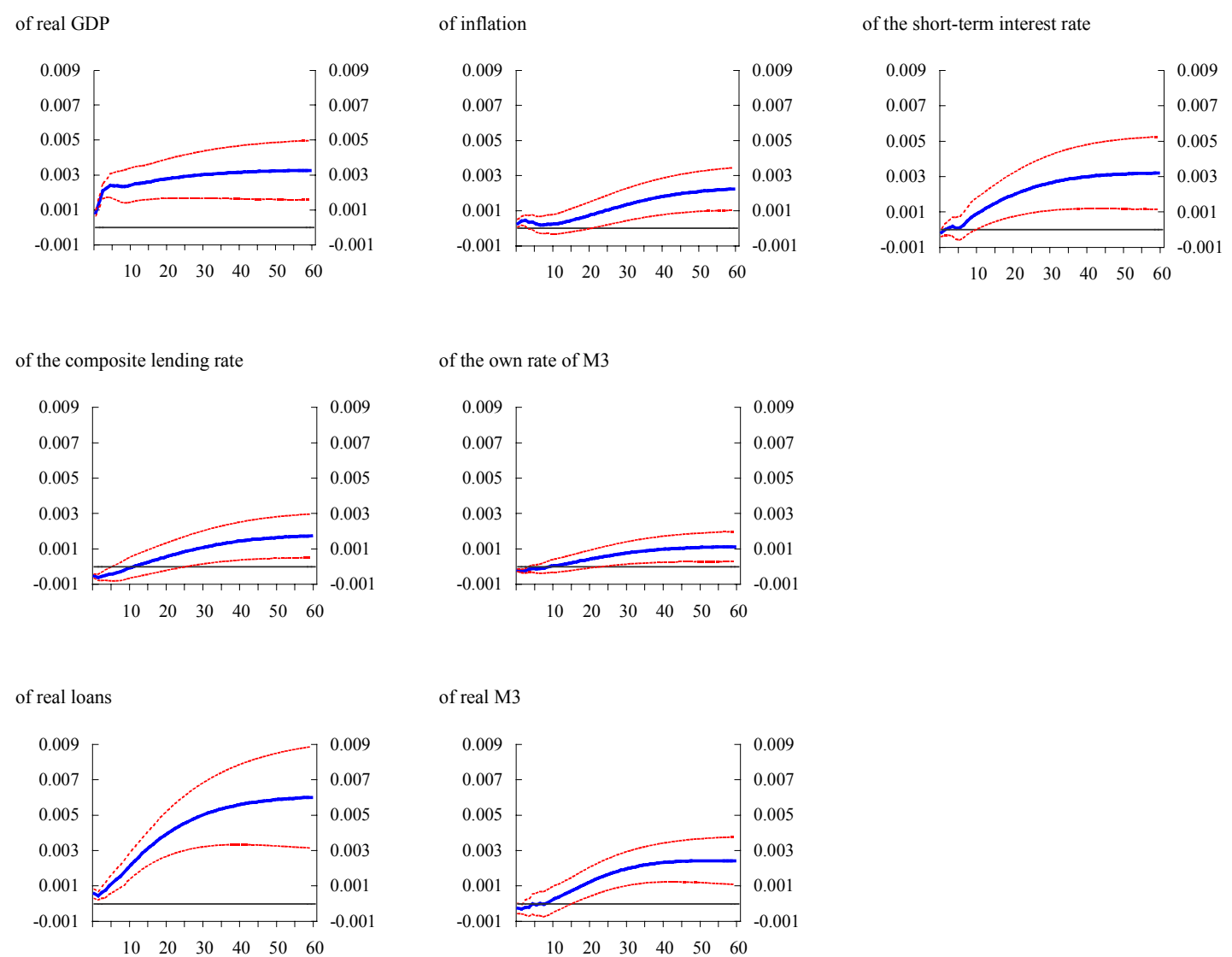

This last permanent shock explains hardly anything of the short-term variability in the variables. At the same time, it explains the major part of the long-term variability in real GDP, real loans, real M3, inflation and the short-term market interest rate. Its contribution to the long-term forecast error variance of the retail bank interest rates is also significant, but the difference as compared with the contributions of the other two permanent shocks is rather limited.

\section{Money demand shock}

Contrary to the evidence in Coenen and Vega (1999), the temporary money demand shock in our model is not found to be orthogonal to all contemporaneous variables. All over-identifying restrictions establishing the simultaneous orthogonality are rejected. In particular, the monetary policy instrument reacts simultaneously. For most variables the effect of the temporary money demand shock becomes insignificant after 1 year and after 3 years all variables have broadly returned to the baseline. In more detail, a temporary positive shock in the real demand for money results in a lagged 
insignificant increase in real output and in a larger temporary increase in inflation. This would suggest that over the sample period considered real money demand shocks were mainly related to transaction balances that were absorbed by higher inflation. At the same time, also shocks that relate to investment balances, held for portfolio reasons, have occurred. Since these balances are expected not to be used for spending and therefore not to have any impact on either real GDP or inflation, the final outcome for the impulse response functions is likely to be somewhat blurred.

The resulting increase in the short-term market interest rate is accompanied, with a lag, by a smaller increase in the retail bank interest rates, i.e. the composite lending rate and the own rate of M3. Finally, there is a temporary positive effect on the real loan demand, which could be due to the decline in the real composite lending rate and to a lesser extent to the small increase in the scale variable. Since the higher real loan demand is matched by the extra deposit financing possibilities of the banking sector, this could also be interpreted as being in accordance with the bank lending channel which suggests that an increase in the deposits supports a higher loan supply.

\section{Chart 7: The impulse response functions to the money demand shock}
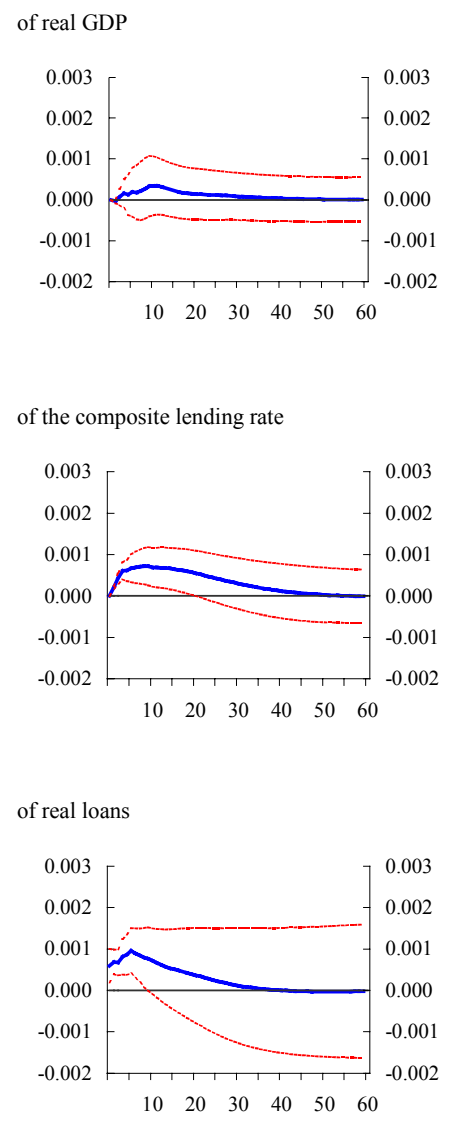

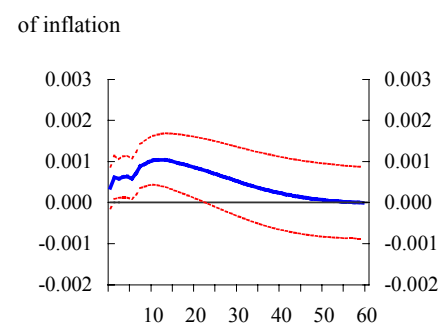

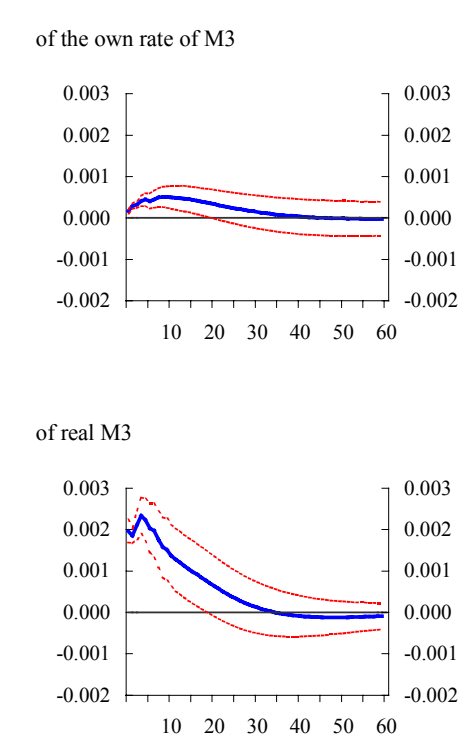
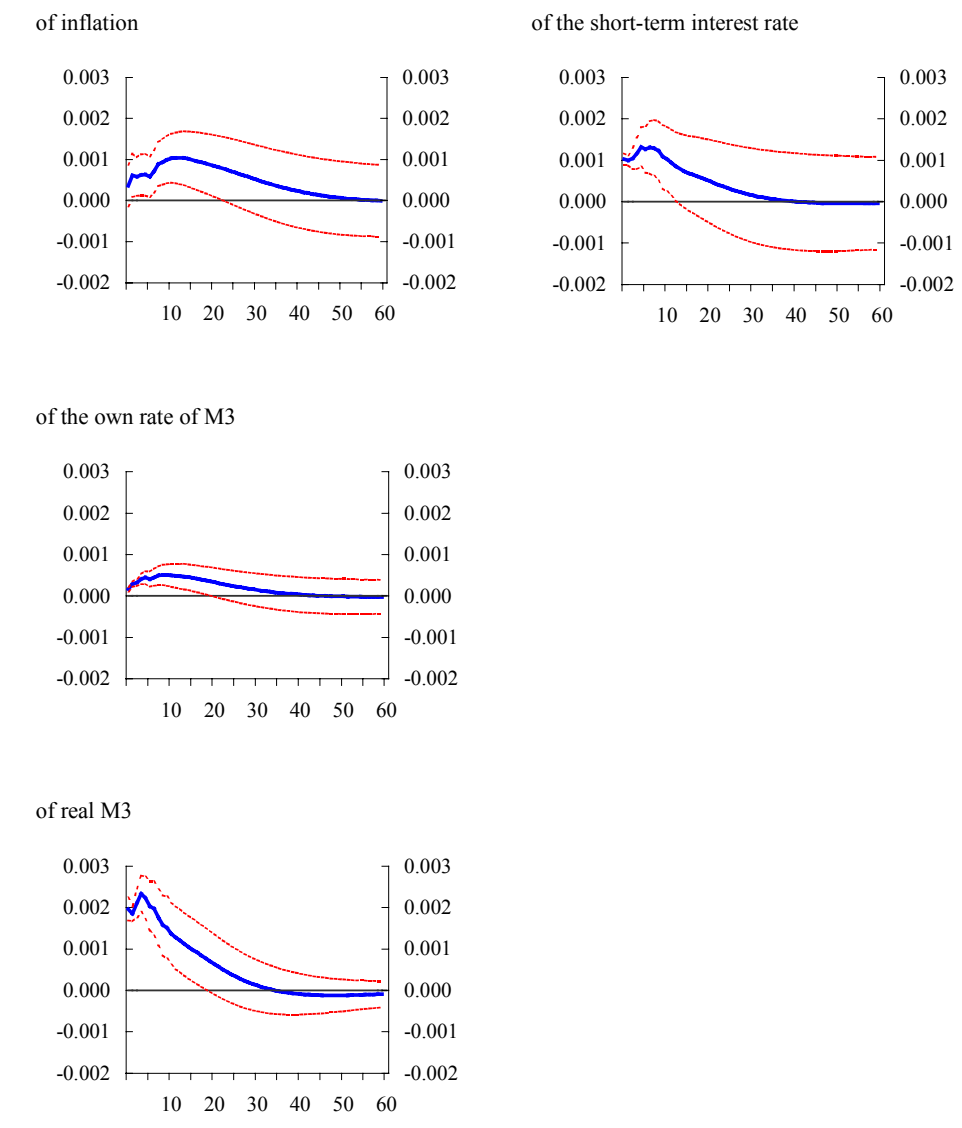
In terms of the FEVDs, the temporary money demand shock explains most of the short-term variability of real M3, but also part of the short-term forecast error variance of the short-term market interest rate. This confirms that this shock can reasonably be labelled as a money demand shock.

\section{Loan demand shock}

Also the effects of the temporary loan demand shock are relatively short-lived. In addition, the IRFs of most variables - except for real M3 and real loans - are very similar to the IRFs with respect to the temporary money demand shock. In more detail, a temporary positive shock in the real demand for loans results in a temporary increase in inflation and has a lagged, limited, positive impact on real GDP. Over the sample period considered real loan demand shocks were driven by both higher consumption and investment activity in the euro area and direct and portfolio investment abroad. If the former had been the only driving factor, the loan demand shock would be expected to affect euro area GDP more strongly. However, because the shocks related to direct and portfolio investment abroad are not expected to have a significant effect on GDP or inflation, the global net effect on the impulse response functions is again rather limited. The higher demand for loans also puts the composite lending rate under pressure due to the possible mismatch between loan supply and loan demand. In real terms, however, the cost of bank lending is hardly affected by the loan demand shock. After a few months, monetary policy is tightened as indicated by the rise in the short-term market interest rate. Subsequently, the retail bank interest rates are increased (further), but to a lesser extent, resulting in a temporary increase in the opportunity costs of holding M3. Notwithstanding this, real demand for money increases somewhat, which seems to be partly related to the increase in real GDP following the loan demand shock.

In terms of the FEVDs, this temporary loan demand shock mainly explains part of the short-term forecast error variance of real loans and to a lesser extent of the composite lending rate and inflation. This confirms that this shock can reasonably be labelled as a loan demand shock. 
Chart 8: The impulse response functions to the loan demand shock
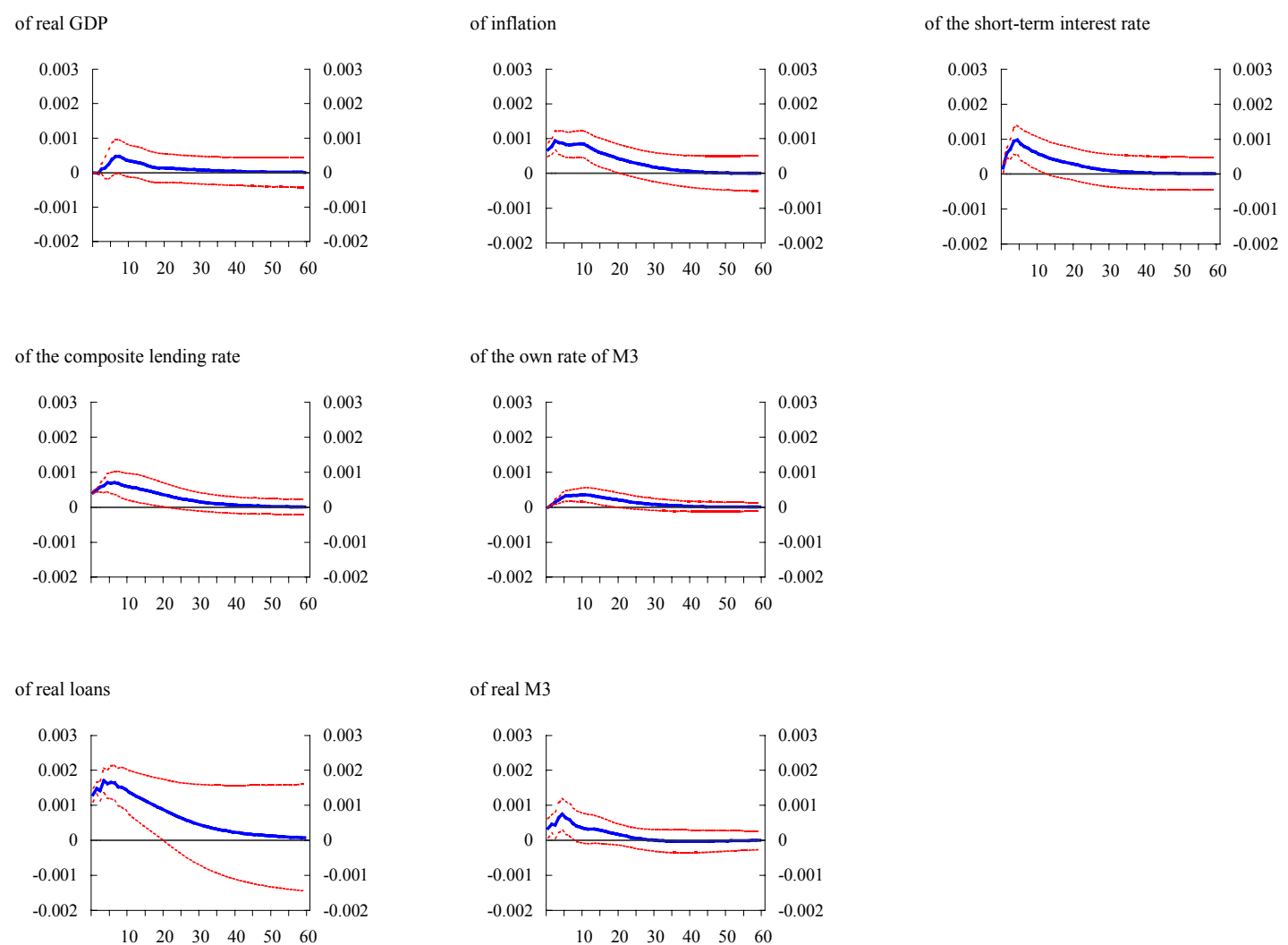

\section{Banking shock: shock in the intermediation margin}

The banking shock is defined as a temporary increase in the intermediation margin of the banks. The increase in the margin mainly results from a reduction in the own rate of M3 and, to a smaller extent, from a rise of the composite lending rate. ${ }^{58}$ In the context of a rather competitive banking sector, it seems reasonable to assume that banks have more room for manoeuvre on the deposit market than on the lending market. The high competition on the lending segment of the retail bank market leaves little room for 'unexplained' changes in these rates. Moreover, there is empirical evidence of banks' reluctance to increase their lending rates too much, to avoid moral hazard and adverse selection problems. The dynamics of the banking shock are quite different from the dynamics of the money demand and the loan demand shocks. As a result of the lower own rate of $\mathrm{M} 3$, the opportunity costs of holding money increase which results in a decline in the real demand for money in the short term (which is more apparent in the smaller money demand model). The relatively small negative

58 An over-identifying zero restriction on the contemporaneous impact on the composite lending rate is rejected by the likelihood ratio test. 
impact on real money demand could be related to the fact that the lower deposit rates may lead agents to spend more money instead of saving it, turning part of their savings balances into transaction balances. Indeed, facing a drop of the deposit rates, agents may be willing to advance their consumption. This hypothesis is supported by the temporary increase in real GDP which is followed by a rise in inflation and in the short-term market interest rate. The IRF of real loans is, however, difficult to interpret and seems to be at odds with the increase in real GDP and the decline in the real composite lending rate. One tentative explanation could be that an increase in the intermediation margin of the banks motivates households and non-financial corporations to rely more on own funds or on other sources of financing from outside the banking sector to finance their consumption and (housing) investment.

\section{Chart 9: The impulse response functions to the banking shock}
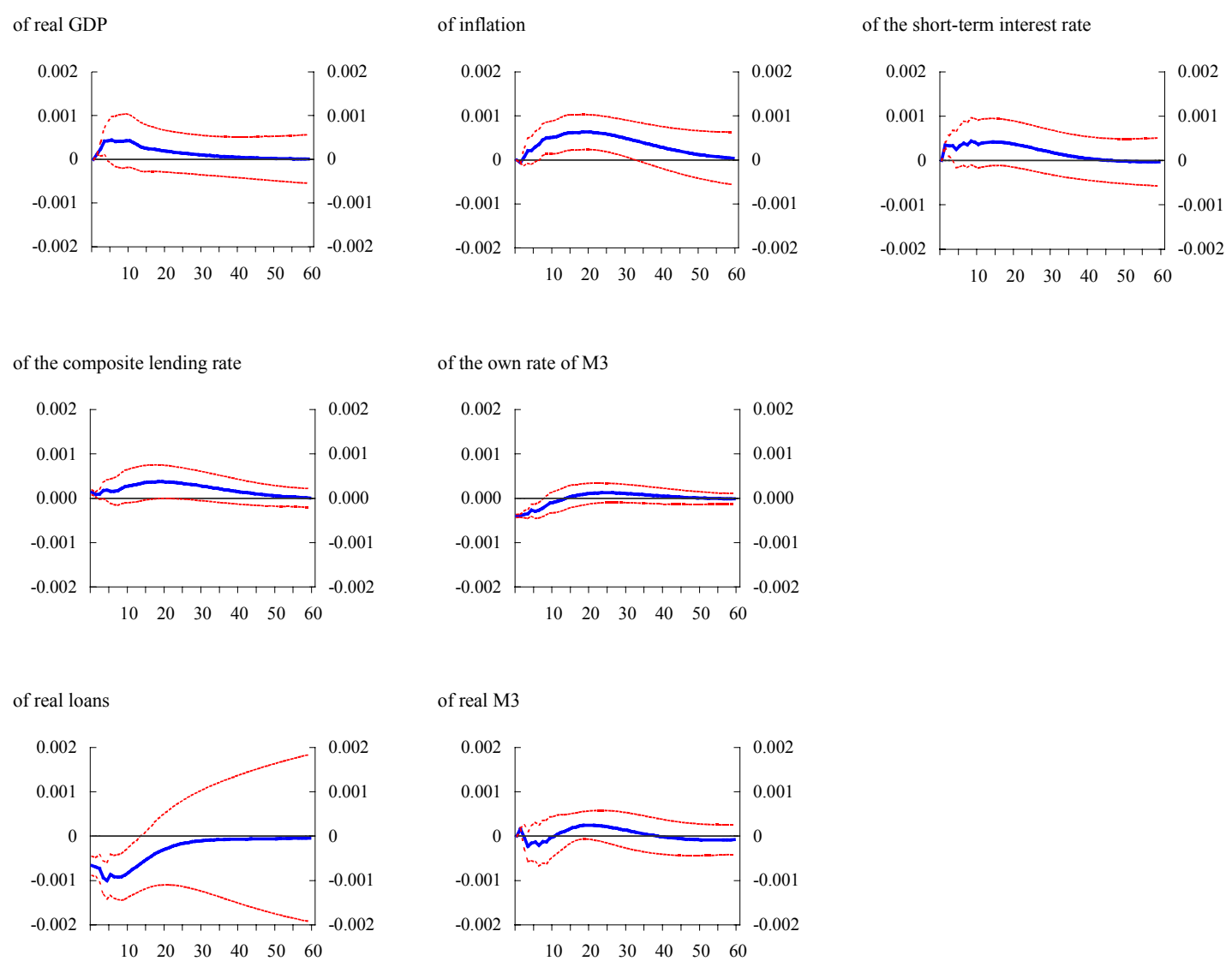

Over the sample period considered, these temporary shocks in banks' intermediation margins seem to have been less important for the dynamics of the whole system than the temporary money demand shocks and the temporary loan demand shocks. In 
addition, in terms of the FEVDs, the banking shock only explains part of the shortterm variability in the own rate of M3.

\section{Monetary policy instrument shock: shock in the short-term market interest rate}

The last temporary shock - a monetary policy instrument shock - is hardly significant and lasts only a few months ${ }^{59}$. As expected, the small positive interest rate shock has a negative, but insignificant impact on real GDP and hardly any impact on the retail bank interest rates. The main impact of this temporary shock is observed for inflation, which drops significantly below the baseline for about one year. Although it is in line with the evidence presented in Coenen and Vega (1999), this very strong and shortlived reaction of inflation is implausible. Further investigation is therefore warranted to obtain a better characterisation of the monetary policy shock.

\section{Chart 10: The impulse response functions to the monetary policy instrument shock}
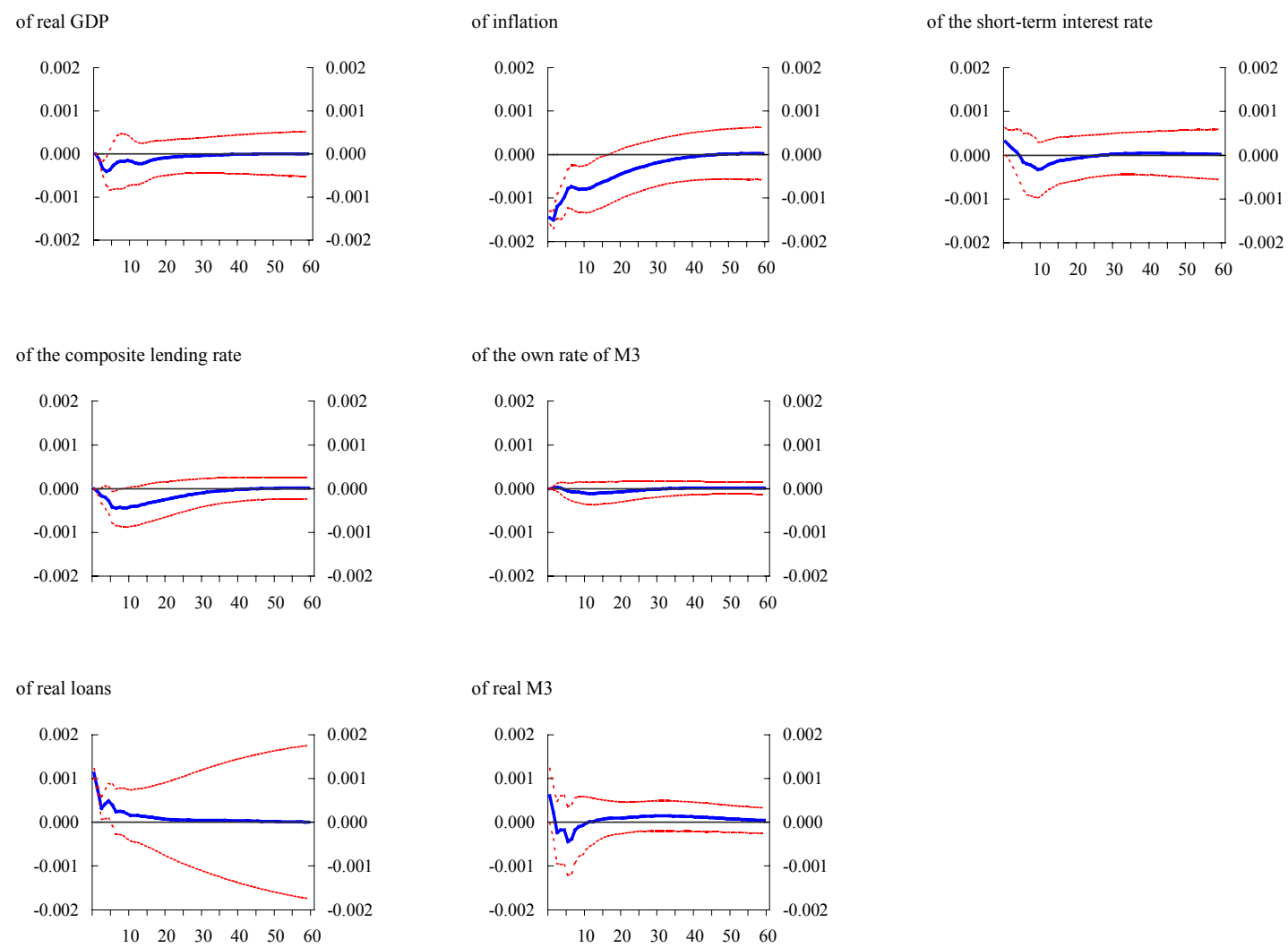

59 In the smaller loan demand model, however, this interest rate shock is larger and dies out more gradually. 
The very short-lived increases in real money holdings and real loan demand seem at odds with the short-run developments in real GDP, the opportunity costs of holding money and the real composite lending rate, but could be related to the sharp drop in inflation. Coenen and Vega (1999) find similar results with respect to the limited reaction of real GDP and real money and the large drop in inflation following an unexpected monetary policy instrument shock.

Given the very strong reaction of inflation to this shock, it is not surprising that the short-term forecast error variance of inflation is almost fully accounted for by this monetary policy instrument shock. However, apart from its implausible impact on inflation, also this last temporary shock seems to have been less important for the dynamics of the system as a whole.

\section{Conclusions}

This paper combines several aspects of monetary analysis: money demand, loan demand and banking intermediation. We start by estimating separately a money demand and a loan demand model which are compared with the existing empirical evidence in order to test for the impact of using monthly data and of explicitly modelling the pass-through from the short-term market interest rate to the retail bank interest rates. These smaller models are then used as a starting point for the identification of the encompassing monetary model with banking intermediation. The advantages of this encompassing model are threefold. First, evidence can be gathered regarding the existence of a bank lending channel of monetary transmission in the euro area, by allowing for loans to react to developments in M3. Second, by allowing for interdependencies between the retail bank interest rates, the pass-through from the short-term market interest rate to the retail bank interest rates can be studied in more detail. Finally, in the context of the encompassing S-VAR model the reaction of all endogenous variables in the model to a number of identified shocks can be analysed.

As a first step, a monthly money demand model is estimated in which the bank intermediation is modelled by means of the pass-through from the short-term market interest rate to a synthetic retail bank deposit rate, i.e. the own rate of M3. From this exercise it follows that the demand for M3 depends positively on real GDP and negatively on the opportunity costs, i.e. the spread between the short-term market 
interest rate and the own rate of M3. Since this is fully in line with the results of Calza, Gerdesmeier and Levy (2001), our results do not seem to be affected by the use of monthly data nor by the inclusion of the short-term market interest rate and the own rate of M3 separately which results in the presence of a second cointegrating vector. The latter can be interpreted as the long-run pass-through which is found to be incomplete, in line with the existing literature. Overall, the stability properties of the money demand model are satisfactory, although a slight gradual increase in the passthrough to the deposit rates can be observed since 1999.

In a similar vein, a monthly loan demand model is estimated in which the bank intermediation is modelled by means of the pass-through from the short-term market interest rate to a synthetic retail bank lending rate, called the composite lending rate. In contrast with the results for the money demand model, the existing results for the demand for loans to the euro area private sector could not be fully replicated in a monthly setting that allows for banking intermediation. In order to obtain satisfactory results in terms of the stability of the long-run parameters of the model, an exogenous variable, capturing the real cash value of mergers and acquisitions of euro area nonfinancial corporations and the UMTS licenses, had to be included. Indeed, the growth rate of real loans to the private sector shows an unprecedented increase in 1999-2000 that resulted in a deviation of the demand for real loans by the private sector from its long-run equilibrium as determined by the developments in real GDP and the real cost of lending. One possible explanation for this strong loan growth is the mergers and acquisitions wave of the late nineties, beginning 2000. The estimated parameters indicate that in the long-run the demand for real loans depends positively on real GDP and on the exogenous variable and negatively on the real cost of bank lending, i.e. the spread between the composite lending rate and the inflation rate. Although the inclusion of the exogenous variable results in much more stable parameter estimates, both the income elasticity and the real bank lending cost semi-elasticity increase somewhat towards the end of the sample. The second cointegrating vector in the loan demand model can be interpreted as the long-run pass-through from the short-term market interest rate to the composite lending rate, which is also found to be incomplete.

When comparing the results of the two separate models, it becomes evident that the link between M3 and the own rate of M3 is much weaker than the link between loans and the composite lending rate. First, the interest rate semi-elasticity of the demand 
for loans is much larger (in absolute value) than the one of the demand for M3. Second, real M3 growth does not react to a disequilibrium in the deposit rate passthrough, while real loan growth declines following a disequilibrium in the lending rate pass-through. Third, the composite lending rate reacts to a loan overhang - i.e. the error correction term of the long-run loan demand equation - while the own rate of M3 does not change in reaction to a monetary overhang, i.e. the error correction term of the long-run money demand equation. Another conclusion that can be derived from this comparison is that the pass-through of the short-term market interest rate to the retail bank lending rates is quicker and stronger than the pass-through to the retail bank deposit rates. Both these findings are confirmed by the results of the monthly encompassing monetary model with banking intermediation.

Overall, the results of the smaller money demand model are recovered fairly well in the encompassing monetary model, but the same does not hold for the results of the smaller loan demand model. While the inclusion of an exogenous variable capturing mergers and acquisitions resulted in a broadly stable loan demand equation in the loan demand model, it appears to be insufficient to stabilise the encompassing monetary model. In particular, the parameter estimates of the real loan demand equation prove to be rather volatile, unlike the parameter estimates of the other three long-run equations. This instability in the loan demand equation seems to be linked to the instability in the adjustment coefficient of real loans with respect to the monetary overhang. We suggest two possible explanations. First, it is very likely that the mergers and acquisitions wave in 1999-2000 has created severe tensions in the lending segment of the retail bank market, which could result in some instability of the link between money and loans. Second, the protracted period of declines in stock prices and the increase in stock market volatility at the end of the sample period considered have, at least temporarily, increased the liquidity preference of investors who have included more safe and liquid assets in their portfolios. The resulting strong growth in money demand could again induce some instability of the link between money and loans. A second difference between the smaller loan demand model and the encompassing monetary model is the long-run pass-through to the composite lending rate. The encompassing model suggests that there exists a positive long-run relationship between the banks' intermediation margin and the short-term market interest rate and that the links between the two retail bank interest rates and the shortterm market interest rate are rather complex in the short term. 
This suggests that banks do not consider the money market to be a perfect substitute for deposits when raising funds, which could be seen as a necessary (but not sufficient) condition for the existence of a bank lending channel. In this respect, further indications can be gathered from the estimated adjustment speeds. The results indicate that the monetary overhang is more important for the dynamics of the whole system than the loan overhang: while all variables except real GDP and the retail bank interest rates react to a monetary overhang, only real loans and the nominal composite lending rate react to a loan overhang. Moreover, the reaction of real loans to a monetary overhang is similar to the reaction of real M3 suggesting that changes in real M3 are followed by similar changes in real loans.

To further analyse the dynamics of the encompassing monetary model impulse response functions and forecast error variance decompositions have been simulated following the method of the common trends. The three permanent shocks - an aggregate supply shock, a nominal or inflation objective shock and an institutional shock reflecting changes in labour market flexibility - are responsible for the main variability of the endogenous variables in the system, in particular in the long run. The four temporary shocks - a money demand shock, a loan demand shock, a banking shock and a monetary policy instrument shock - have only a limited impact which is restricted to the short and medium run. The money demand shock affects mainly real money demand and inflation. Similarly, the loan demand shock impinges on itself and on inflation.

Overall, the results in this paper do provide evidence of some clear links between money and the retail bank deposit rates on the one hand and loans and the retail bank lending rates on the other. Real loans to the private sector seem to react negatively together with real M3 - to a monetary overhang, although this link seems to have become unstable towards the end of the sample period considered. The opposite reaction of real M3 to a loan overhang is however not supported by the data. This could be seen as evidence of the developments in real loans mirroring the developments in real M3 as suggested by the bank lending channel. This hypothesis is also supported by the response pattern of real loans to a temporary money demand shock. At the same time, real M3 also seems to react to a temporary loan demand shock, which suggests that the links between deposits and loans are of a more complex nature. A final (indirect) link is reflected in the long-run relationship 
between the synthetic retail bank deposit rate, the synthetic retail bank lending rate and the short-term market interest rate. This relation indicates that a more restrictive monetary policy will raise both the opportunity costs of holding money and the real cost of bank lending, which then results in lower money holdings and a reduced demand for loans. In addition, the relation could be interpreted as suggesting that banks may use deposits as a marginal buffer to finance their lending activity and consequently take their deposit rates into account when deciding on their lending rates. However, the dynamic link between the two types of retail bank interest rates is rather complex.

Further research could focus on the inclusion of additional exogenous variables, like e.g. house prices, that might help to further stabilise the loan demand equation. In addition, it could be envisaged to extend the models by including financial market variables - such as e.g. long-term bond yields, stock prices and stock market volatility measures - in order to consider the full range of alternative assets to M3. 


\section{References}

Allen, F. and A. Santomero, 1998, The theory of financial intermediation, Journal of Banking and Finance, Vol. 21, No. 11-12, 1461-1485.

Amisano, G. and C. Giannini, 1997, Topics in Structural VAR Econometrics, Second, revised and enlarged edition, Springer-Verlag, Berlin.

Angeloni, I., 1994, The Bank of Italy monthly money market model, Economic Modelling, Vol. 11, No. 4, 387-412.

Angeloni, I., Kashyap, A. and B. Mojon (eds.), 2003, Monetary transmission in the euro area, Cambridge University Press, forthcoming.

Angeloni, I., Kashyap, A., Mojon, B. and D. Terlizzese, 2002, Monetary transmission in the euro area: Where do we stand?, ECB Working Paper, 114.

Berger, A., Kyle, M. and J Scalise, 2001, Did US bank supervisors get tougher during the credit crunch? Did they get easier during the credit boom? Did it matter to bank lending?, in F. Mishkin (ed), 2001, Prudential supervision: What works and what doesn't, NBER University of Chicago Press, Chicago, IL, 301-349.

Berger, A and G. Udell, 1992, Some evidence on the empirical significance of credit rationing, Journal of Political Economy, Vol. 100, No. 5, 1047-1077.

Berger, A. and G. Udell, 2003, The institutional memory hypothesis and the procyclicality of bank lending behaviour, BIS Working paper, 125.

Berlin, M. and L. Mester, 1998, On the profitability and cost relationship lending, Journal of Banking and Finance, Vol. 22, No. 6-8, 873-897.

Bernanke, B., 1993, Credit in the macroeconomy, Federal Reserve Bank of New York, Quarterly Review, Vol. 18, No. 1, 50-70.

Bernanke, B. and A. Blinder, 1988, Is it money or credit, or both, or neither ? Credit, Money, and Aggregate Demand., American Economic Review, Vol. 78, No. 2, 435-439

Bernanke, B. and A. Blinder, 1992, The federal funds rate and the channels of monetary transmission, American Economic Review, Vol. 82, No. 4, 901-921.

Bernanke, B. and M. Gertler, 1995, Inside the black box: The credit channel of monetary policy Journal of Economic Perspectives, Vol. 9, No. 4, 27-48.

Blanchard, O. and D. Quah, 1989, The dynamic effects of aggregate demand and supply disturbances, American Economic Review, Vol. 79, No. 4, 655-673.

Borio, C. and W. Fritz, 1995, The response of short-term bank lending rates to policy rates: A crosscountry perspective, BIS Working Paper, 27.

Brand, C. and N. Cassola, 2000, A money demand system for euro area M3, ECB Working paper, 39.

Brigden, A. and P. Mizen, 1999, Money, credit and investment in the UK corporate sector, Bank of England Working paper, 100.

Calza, A, Gartner, C. and J. Sousa, 2003, Modelling the demand for loans to the private sector in the euro-area, Applied Economics, Vol. 35, No. 1, 107-117.

Calza, A., Gerdesmeier, D. and J. Levy, 2001, Euro area money demand: measuring the opportunity costs appropriately, IMF Working Paper, 01/179. 
Calza, A., Marnique, M. and J. Sousa, 2003, The determinants of the behaviour of aggregate loans to the private sector in the Euro area, ECB Working Paper, 202.

Cassola, N. and C. Morana, 2002, Monetary policy and the stock market in the Euro area, ECB Working paper, 119.

Chiappori, P-A., Perez-Castrillo, D. and T. Verdier, 1995, Spatial competition in the banking system: Localization, cross subsidies and the regulation of deposit rates, European Economic Review, Vol. 39, No. 5, 889-918.

Chow, G. and A. Lin, 1971, Best linear unbiased interpolation, distribution and extrapolation of time series by related series, Review of Economics and Statistics, Vol. 53, No. 4, 372-375.

Chrystal, K. and P. Mizen, 2001(a), Consumption, money and lending: a joint model for the UK household sector, Bank of England Working Paper, 134.

Chrystal, K. and P. Mizen, 2001(b), Other financial corporations: Cinderella or ugly sister of empirical monetary economics?, Bank of England Working paper, 151.

Coenen, G. and J-L. Vega, 1999, The demand for M3 in the euro area, ECB Working Paper, 6

Coenen, G. and J-L. Vega, 2001, The demand for M3 in the euro area, Journal of Applied Econometrics, Vol. 16, No. 6, 727-748.

Cottarelli, C. and A. Kourelis, 1994, Financial structure, bank lending rates, and the transmission mechanism of monetary policy, IMF Staff Papers, Vol. 41, No. 4, 587-623.

de Bondt, G., 2002, Retail bank interest rate pass-through: new evidence at the Euro area level, $E C B$ Working Paper, 136.

de Bondt, G., B. Mojon and N. Valla, 2003, Term structure and the sluggishness of retail bank rates in euro area countries, ECB Working Paper, forthcoming

Dermine, J., 1986, Deposit rates, credit rates and bank capital, Journal of Banking and Finance, Vol. 10, No. 1, 99-114.

Dhar, S., Pain, D. and R. Thomas, 2000, A small structural empirical model for the UK monetary transmission mechanism, Bank of England Working Paper, 113.

Diamond, D. and R. Rajan, 2000, A theory of bank capital, The Journal of Finance, Vol. 55, No. 6, 2431-2465.

Enders, W., 1995, Applied Econometrics Time Series, Wiley International Edition, John Wiley \& Sons, Inc, New-York.

Engle, R., Hendry, D. and J.-F. Richard, 1983, Exogeneity, Econometrica, Vol. 51, No. 2, $277-304$.

Fama, E., 1985, What's different about banks?, Journal of Monetary Economics, Vol. 15, No. 1, $29-39$.

Freixas, X. and J-C. Rochet, 1997, Microeconomics of Banking, MIT Press

Gertler, M. and S. Gilchrist, 1993, The role of credit market imperfections in the monetary transmission mechanism: Arguments and evidence, Scandinavian Journal of Economics, Vol. 95, No. 1, 43-64.

Hannan, T. and A. Berger, 1991, The rigidity of prices: Evidence from the banking sector, American Economic Review, Vol. 81, No. 4, 938-945.

Harbo, I., Johansen, S., Nielsen, B. and A. Rahbek, 1998, Asymptotic Inference on Cointegration Rank in Partial Systems, Journal of Business \& Economic Statistics, Vol. 16, No. 4, 388-399.

Hubrich, K. and P.J.G. Vlaar, 2001, Monetary transmission in Germany: Lessons for the euro area, DNB Staff Reports, 57. 
Hubrich, K. and P. Vlaar, 2003, Monetary transmission in Germany: Lessons for the euro area, Empirical Economics, forthcoming.

Issing, O., 2001, The importance of monetary analysis, in Klöckers, H-J. and C. Willeke (Eds.), Monetary analysis: tools and applications, proceedings of the seminar held at the ECB on 20 and 21 November 2000, 5-7.

Johansen, S., 1995, Likelihood-based Inference in Cointegration Vector Autoregressive Models, Oxford University Press, Oxford.

Johansen, S. and B. Nielsen, 1993, Asymptotics for Cointegration Rank tests in the Presence of Intervention Dummies - Manual for the simulation program DisCo, program and manual available at http://www.nuff.ox.ac.uk/users/nielsen/disco.html.

Juselius, K., 1993, VAR modelling and Haavelmo's probability approach to macroeconomic modelling, Empirical Economics, Vol. 18, No. 4, 595-622.

Juselius, K. and R. MacDonald, 2000, International parity relationships between Germany and the United States: A joint modelling approach, Discussion Paper 00-10, Institute of Economics, University of Copenhagen.

Kashyap, A., Rajan, R. and J. Stein, 2002, Banks as liquidity providers: An explanation for the coexistence of lending and deposit-taking, Journal of Finance, Vol. 57, No. 1, 33-73.

Kashyap, A. and J. Stein, 2000, What do a million observations on banks have to say about the transmission of monetary policy, American Economic Review, Vol. 90, No. 3, 407-428.

Kieler, M., 2003, The ECB's inflation objective, IMF Working Paper, 03/91.

King, R., Plosser, C., Stock, J. and W. Watson, 1991, Stochastic trends and economic fluctuations, American Economic Review, Vol. 81, No. 4, 819-840.

Klein, M., 1971, A theory of the banking firm, Journal of Money, Credit and Banking, Vol. 3, 205-18.

Klöckers, H-J. and C. Willeke, Monetary analysis: tools and applications, August 2001, proceedings of the seminar held at the ECB on 20 and 21 November 2000.

Mojon, B., 2000, Financial structure and the interest rate channel of the ECB monetary policy, $E C B$ Working Paper, 40.

Monti, M., 1972, Deposit, credit and interest rate determination under alternative bank objectives, in Mathematical methods in investment and finance, ed. G. Szego and K. Shell. Amsterdam: NorthHolland.

Mosconi, R., 1998, MALCOLM, Cafoscarina, Venezia.

Pesaran, P., Shin, Y. and R. Smith, 2000, Structural Analysis of Vector Error Correction Models with Exogenous I(1) Variables, Journal of Econometrics, Vol. 97, No. 2, 293-343.

Rahbek, A. and R. Mosconi, 1999, Cointegration Rank Inference with Stationary Regressors in VAR Models, Econometrics Journal, Vol. 2, No. 1, 76-91.

Rünstler, G. and F. Sédillot, 2002, Short-term estimates of euro area real GDP by means of monthly data, mimeo.

Sims, C., 1980, Macroeconomics and reality, Econometrica, Vol. 48, No. 1, 1-48.

Sriram, S., 1999, Survey of literature on demand for money: theoretical and empirical work with special reference to Error-correction-models, IMF Working Paper, 99/64. 
Stahl, D., 1988, Bertrand competition for inputs and Walrasian outcomes, American Economic Review, Vol. 78, No. 1, 189-201.

Stein, J., 1998, An adverse-selection model of bank asset and liability management with implications for the transmission of monetary policy, RAND Journal of Economics, Vol. 29, No. 3, 466-486.

Stock, J. and W. Watson, 1988, Testing for common trends, Journal of the American Statistical Association, Vol. 83, No. 404, 1097-1107.

Vlaar, P., 1998, On the asymptotic distribution of impulse response functions with long-run restrictions, DNB Staff Report, 22.

Vlaar, P. and H. Schubert, 1999, Monetary transmission and controllability of money in Europe: a structural vector error correction approach, DNB Staff Report, 36.

Warne, A., 1993, A common trend model: Identification, estimation and inference, Seminar Paper No.555, IIES, Stockholm University.

Yanelle, M-O., 1989, The strategic analysis of intermediation, European Economic Review, Vol. 33, No. 2, 294-301.

Yanelle, M-O., 1997, Banking competition and market efficiency, Review of Economics Studies, Vol. 64, 215-239. 


\section{Appendix I: Data appendix}

The range of the sample is January 1981 until September 2001, for all series except for the cash value of mergers and acquisitions that starts in January 1985. All the series are aggregated series for the euro area covering the countries comprising the euro area at each given time, i.e. 11 Member States up to December 2000 and 12 Member States from January 2001 onwards. When no monthly data were available, quarterly data have been interpolated.

\section{Real GDP}

Euro area quarterly data on real GDP are constructed by averaging seasonally adjusted national accounts data. These quarterly data on real GDP have been interpolated by means of the Chow and Lin procedure (1971). This procedure uses the seasonally adjusted quarterly real GDP series and some additional monthly information to construct the new monthly real GDP series. In this paper the monthly information used is the indicator of economic sentiment provided by the EC surveys.

\section{GDP deflator}

Quarterly data on the GDP deflator have been interpolated by using the same technique as for real GDP. For this price variable, the monthly series used are the HICP and an index of world commodity prices.

\section{Real M3}

The real money series is based on the broad monetary aggregate M3 that has been deflated by the monthly GDP deflator. Until September 1997 the M3 series is based on stocks data, from October 1997 flows statistics have been used. Data have been seasonally adjusted at the euro area level. M3 includes currency in circulation, overnight deposits, short-term savings deposits, short-term time deposits and marketable instruments.

\section{Real loans to the private sector}

The series of real loans is based on the aggregate labelled 'euro area MFI loans to the private sector', deflated by the monthly GDP deflator. Until September 1997 the series is based on stocks data, from October 1997 flows statistics have been used. Data have been seasonally adjusted at the euro area level. Included are several types of loans to households and non-financial corporations, both with short and long maturities. 


\section{The short-term market interest rate or policy instrument}

This is the three-month money market rate of the euro area. Up to December 1998 this is a weighted average of the national short-term market interest rates. From January 1999 the three-month EURIBOR is used.

\section{The own rate of return of $M 3$}

The own rate of return of M3 is a synthetic bank deposit rate constructed as a weighted average of the own rates of return of all components of M3. The weights represent the share of each component with respect to the total.

\section{The composite lending rate}

The composite lending rate is a synthetic bank lending rate constructed as a weighted average of the rates charged by banks on all components included in the loans to the private sector aggregate. The weights represent the share of each loan category with respect to the total. For more details, see Calza, Manrique and Sousa (2003).

\section{Inflation}

The inflation rate is computed as the twelve-month difference in the natural logarithms of the HICP.

\section{The real cash-value of mergers and acquisitions}

The real cash value of mergers and acquisitions series is constructed on the basis of individual observations of mergers and acquisitions collected in the Thomson financial securities database as of beginning of 2002. The database includes all mergers involving a company from the euro area as an acquirer. The targets of the mergers are either EMU members or not. The value of the UMTS auction operations is added on the following dates: April 2000, June 200, July 2000 and August 2000. The series is in billion euros and is deflated by the monthly GDP deflator. The series starts in January 1985. For the previous years, a constant value equal to the January 1985 observation is introduced. 
Chart AI. 1: Short-term market interest rate, composite lending rate and own rate of return of $\mathrm{M} 3$

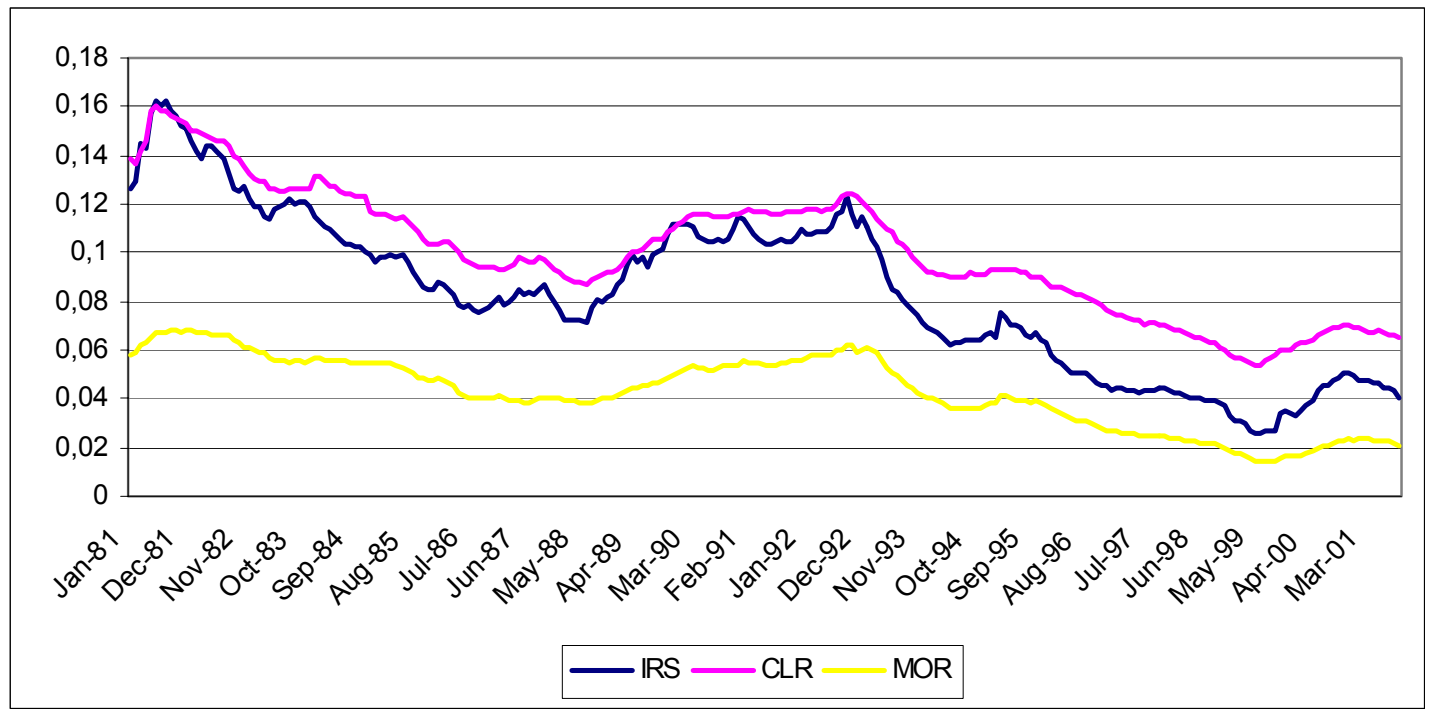

Note: The interest rates are in decimals. Source ECB.

\section{Chart AI. 2: Inflation, short-term market interest rate and real interest rate}

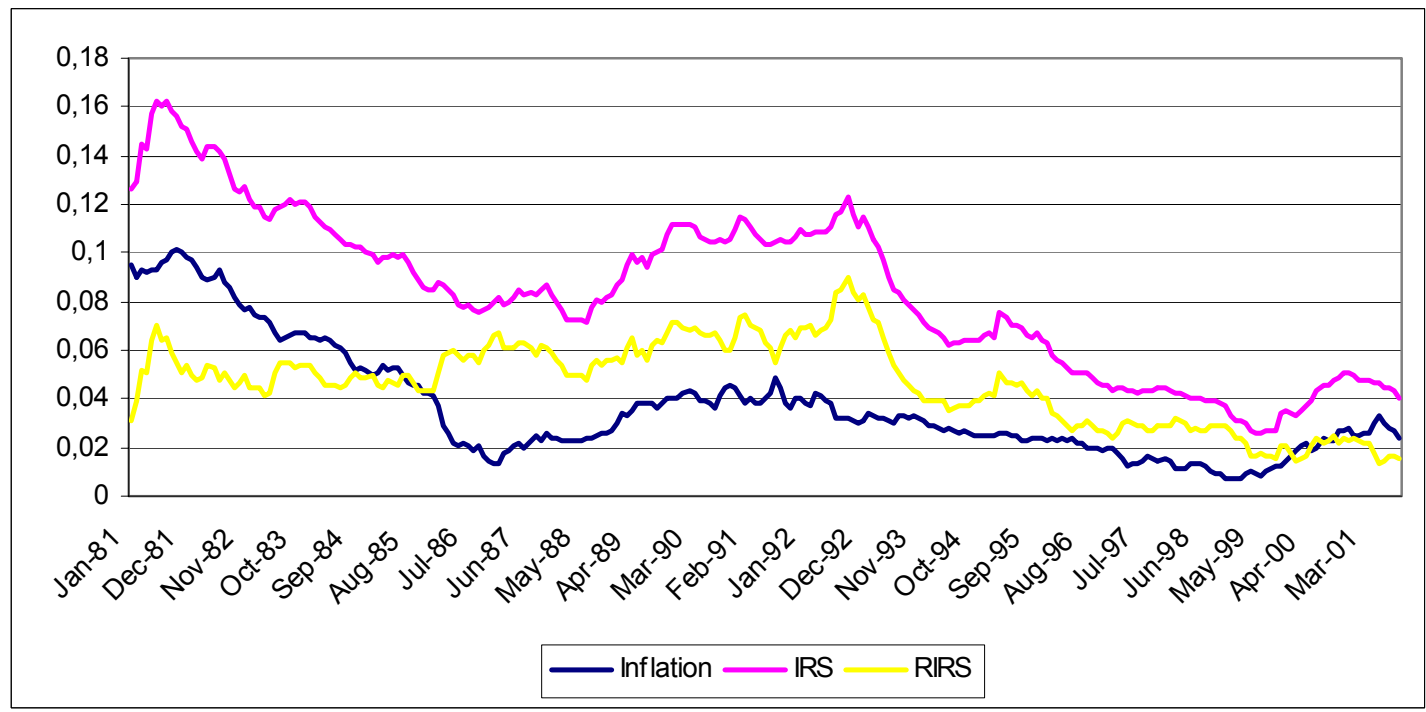

Note: Inflation, the short-term market interest rate and the real interest rate are in decimals. Source ECB. 
Chart AI. 3: Real M3 and real loan growth

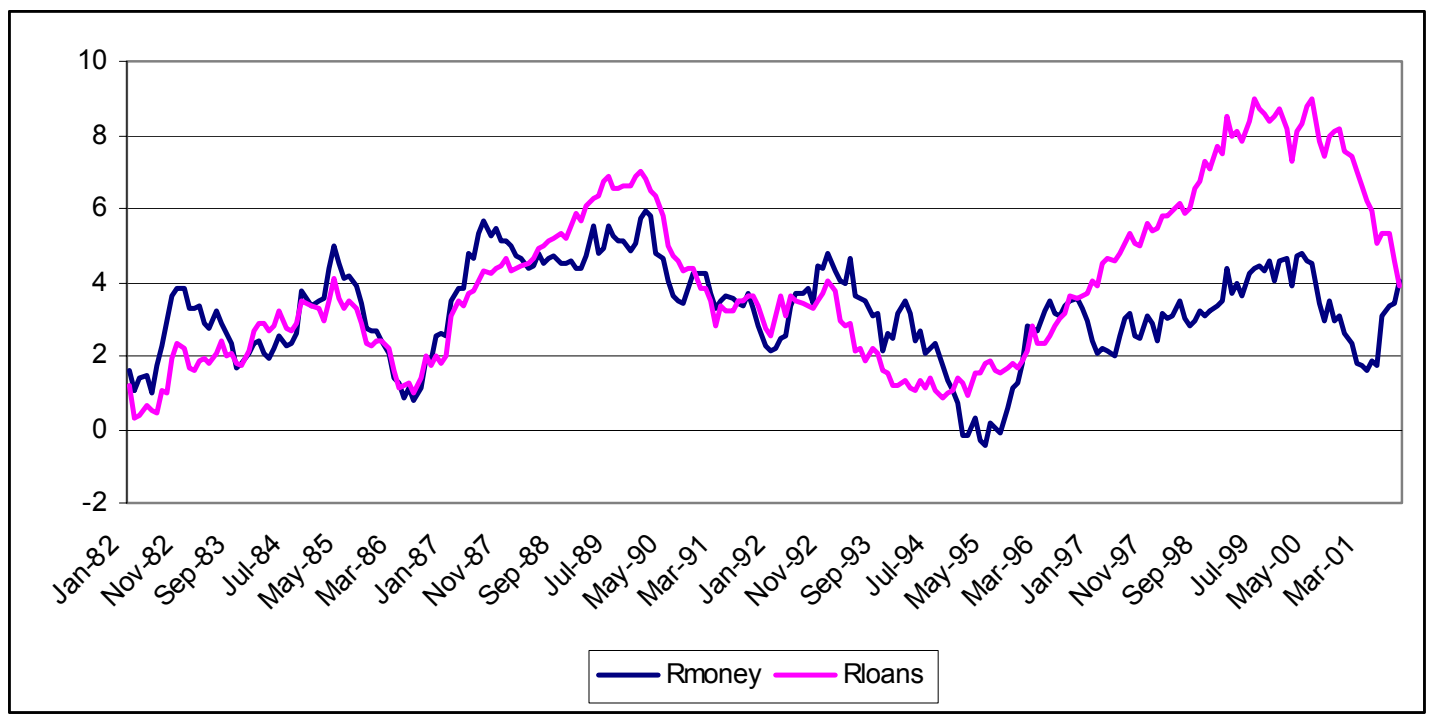

Note: Real money and Real loans are expressed in percentage. Annual percentage changes. Source ECB and computation by the authors.

\section{Chart AI. 4: GDP and real money growth}

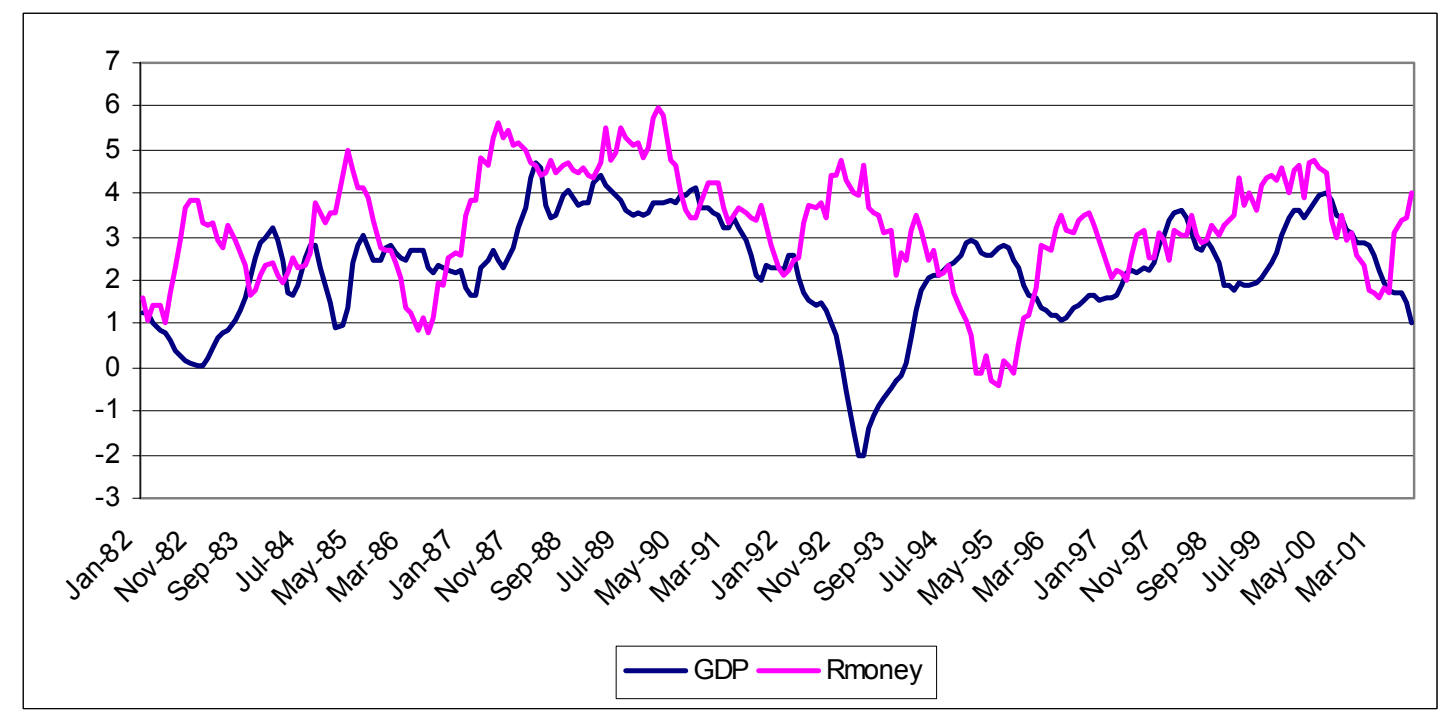

Note: GDP and Real money are expressed in percentage. Annual percentage changes. Source ECB and computation by the authors. 


\section{Chart AI. 5: GDP and real loan growth}

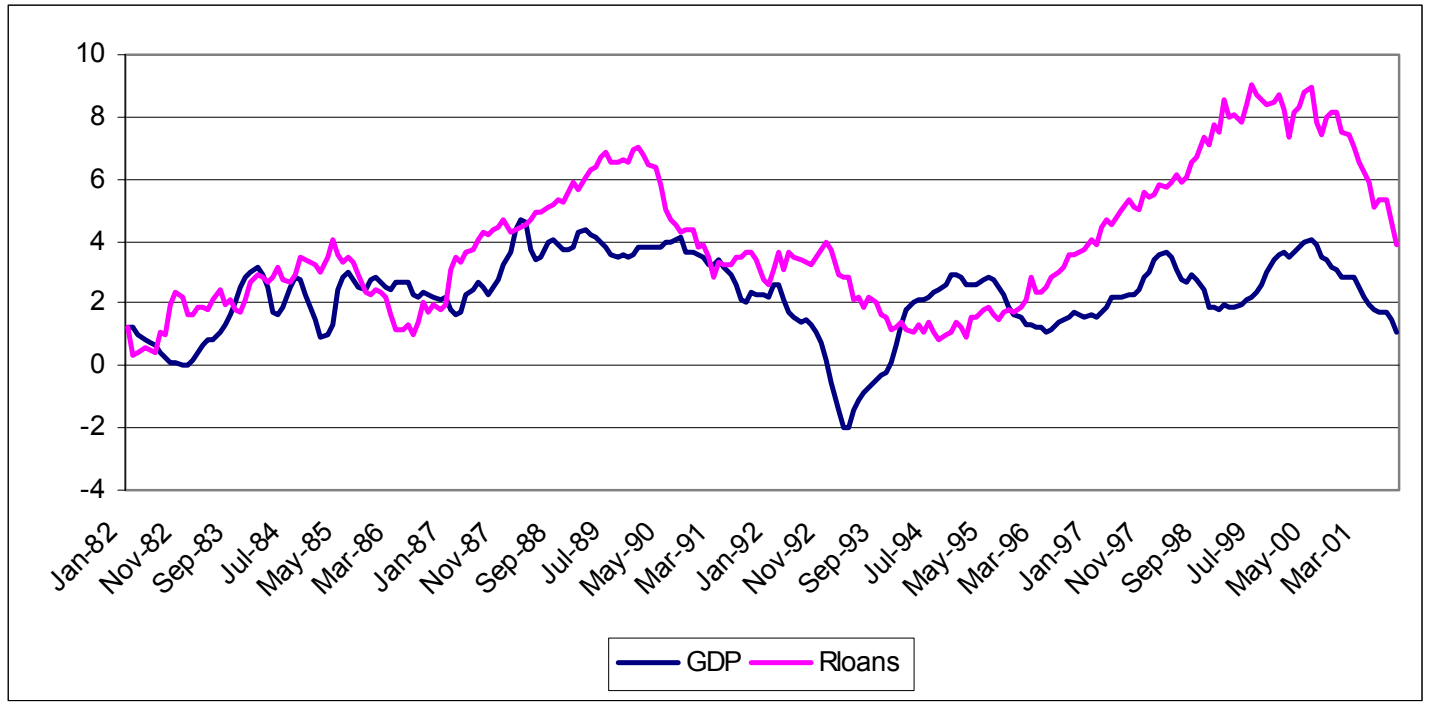

Note: GDP and Real loans are expressed in percentage. Annual percentage changes. Source ECB and computation by the authors.

\section{Chart AI. 6: Real cash-value of mergers and acquisitions}

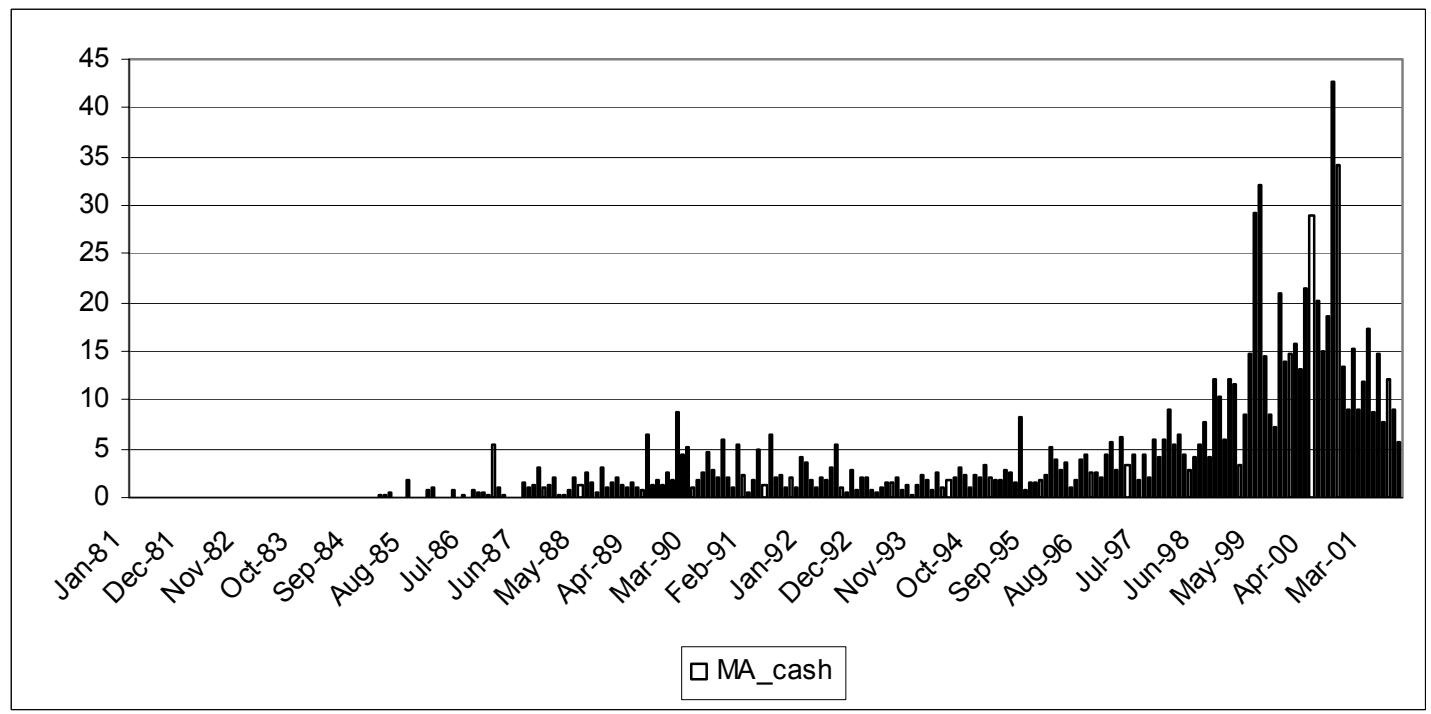

Note: Cash value of mergers and acquisitions in billion euros. Source Thomson data and computations by the authors. 
Appendix II: Cointegration analysis: Money demand model

Table AII. 1: Johansen's trace test for the money demand model

\begin{tabular}{ccccc}
\hline Rank & $\begin{array}{c}\text { Eigenvalue } \\
\text { with } \\
\text { dummies }\end{array}$ & $\begin{array}{c}\text { Trace test } \\
\text { with dummies }\end{array}$ & $\begin{array}{c}\text { Trace test } \\
\text { without } \\
\text { dummies }\end{array}$ & $\begin{array}{c}\text { Critical Value } \\
\text { at 95\% }\end{array}$ \\
\hline 0 & & 53.82 & $53.15^{* *}$ & 47.2 \\
1 & 0.094 & 29.89 & $29.43^{*}$ & 29.7 \\
2 & 0.085 & 8.38 & 8.65 & 15.4 \\
3 & 0.033 & 0.14 & 0.08 & 3.8 \\
\hline Note: *,** indicate that the null hypotheses are rejected at respectively $10 \%$ and $5 \%$.
\end{tabular}

Chart AII. 1: Cointegrating vectors: demand for money and deposit rate pass-through
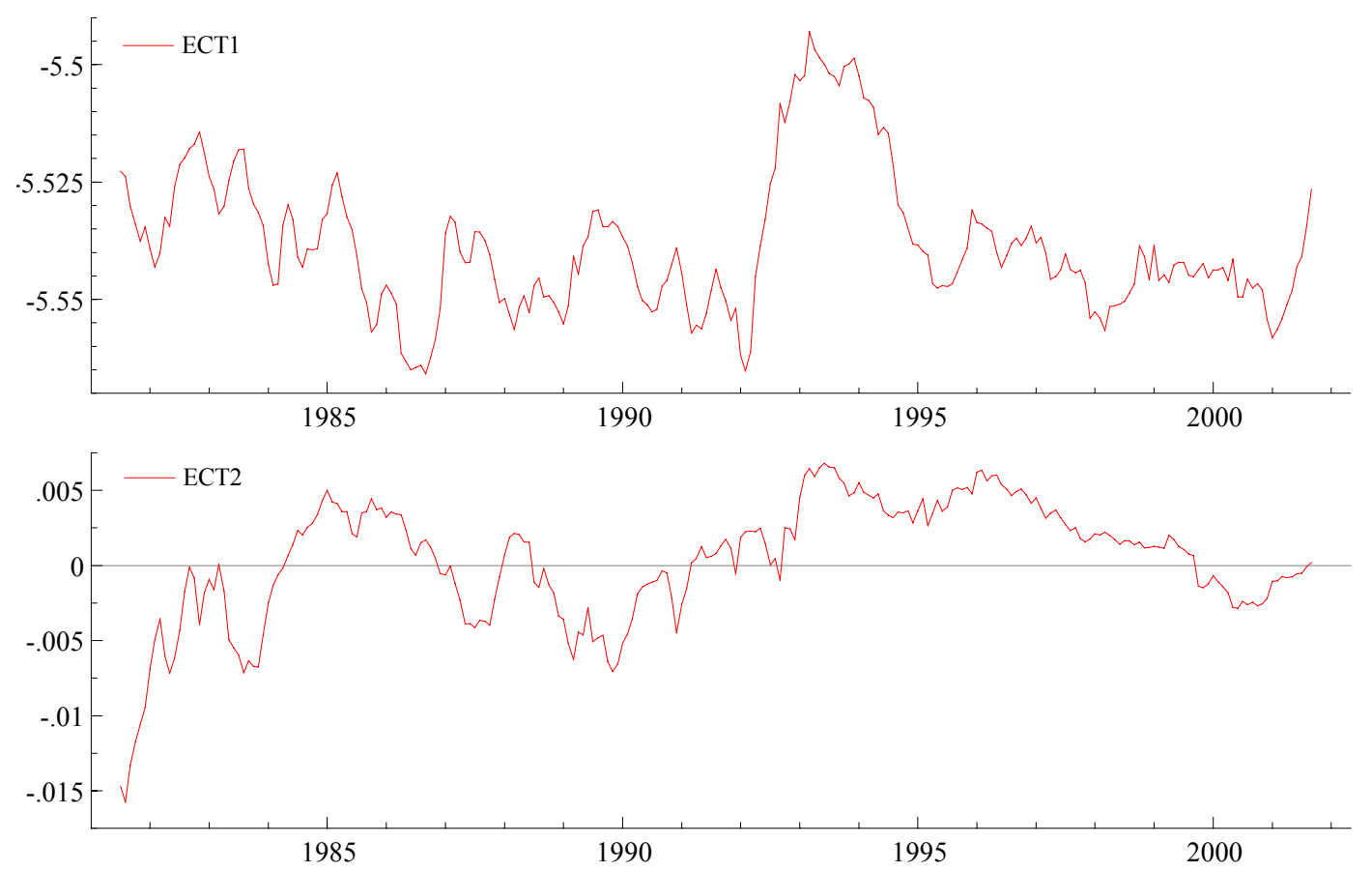
Chart AII. 2: Recursive Chi-square test for the money demand model

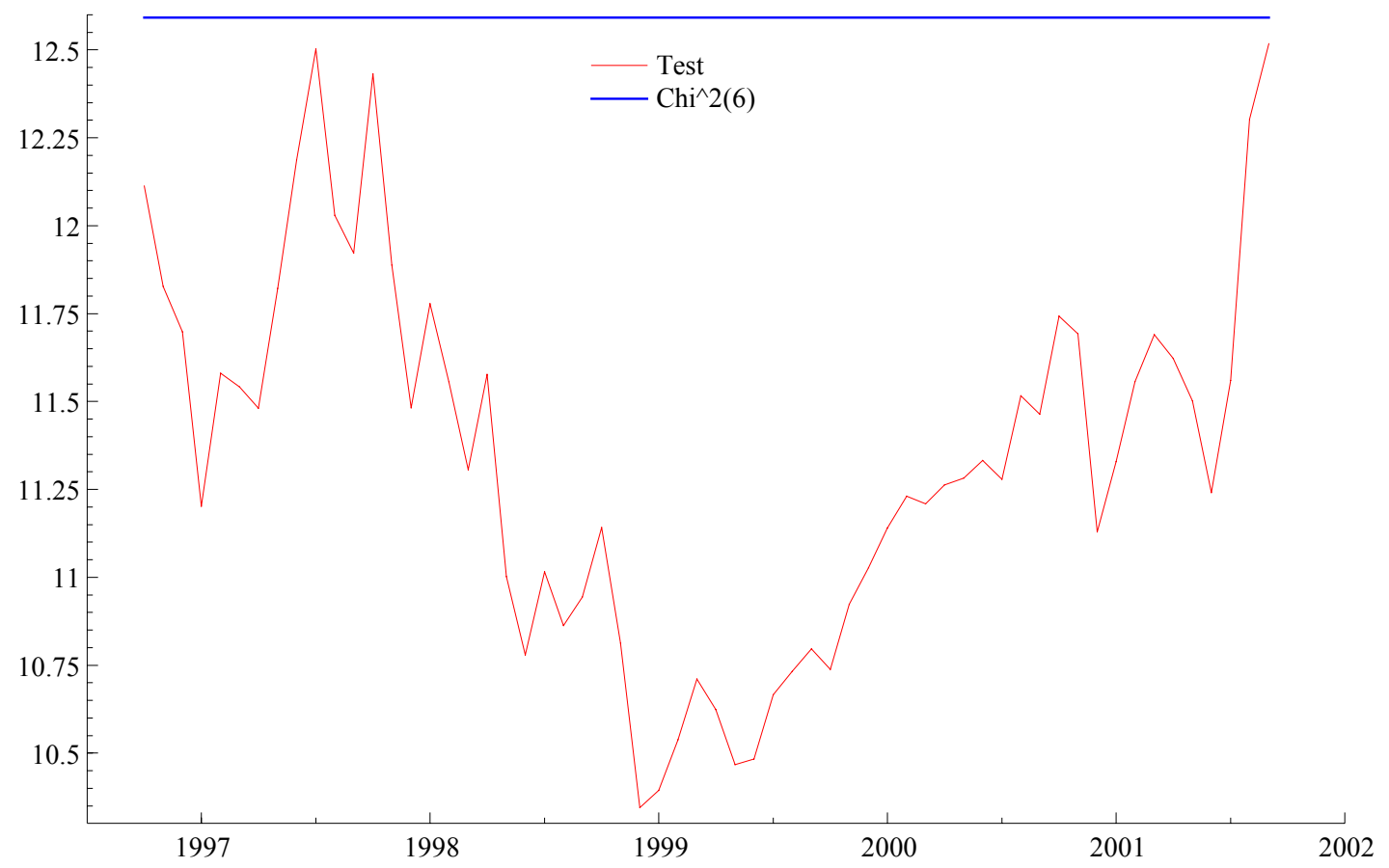




\section{Appendix III: Cointegration analysis: Loan demand model}

Table AIII. 1: Johansen's trace test for the loan demand model

\begin{tabular}{cccccc}
\hline Rank & $\begin{array}{c}\text { Eigenvalue } \\
\text { with dummy } \\
\text { and } \\
\text { exogenous }\end{array}$ & $\begin{array}{c}\text { Trace test } \\
\text { with } \\
\text { dummy and } \\
\text { exogenous }\end{array}$ & $\begin{array}{c}\text { Trace test } \\
\text { without } \\
\text { dummy and } \\
\text { exogenous }\end{array}$ & $\begin{array}{c}\text { Critical Value } \\
\text { at 95\% }\end{array}$ & $\begin{array}{c}\text { Critical Value } \\
\text { at 95\% } \\
\text { corrected for } \\
\text { the exogenous } \\
\text { variable }\end{array}$ \\
\hline 0 & & 68.98 & 54.76 & 68.5 & 81.45 \\
1 & 0.133 & 34.35 & 30.87 & 47.2 & 58.63 \\
2 & 0.070 & 16.71 & 14.49 & 29.7 & 38.93 \\
3 & 0.036 & 7.77 & 5.51 & 15.4 & 23.32 \\
4 & 0.026 & 1.47 & 0.46 & 3.8 & 11.47 \\
\hline
\end{tabular}

Note: The critical values corrected for the exogenous are taken from Table 3 of Pesaran et al (2000).

Chart AIII. 1: Cointegrating vectors: demand for loans to the private sector and lending rate pass-through
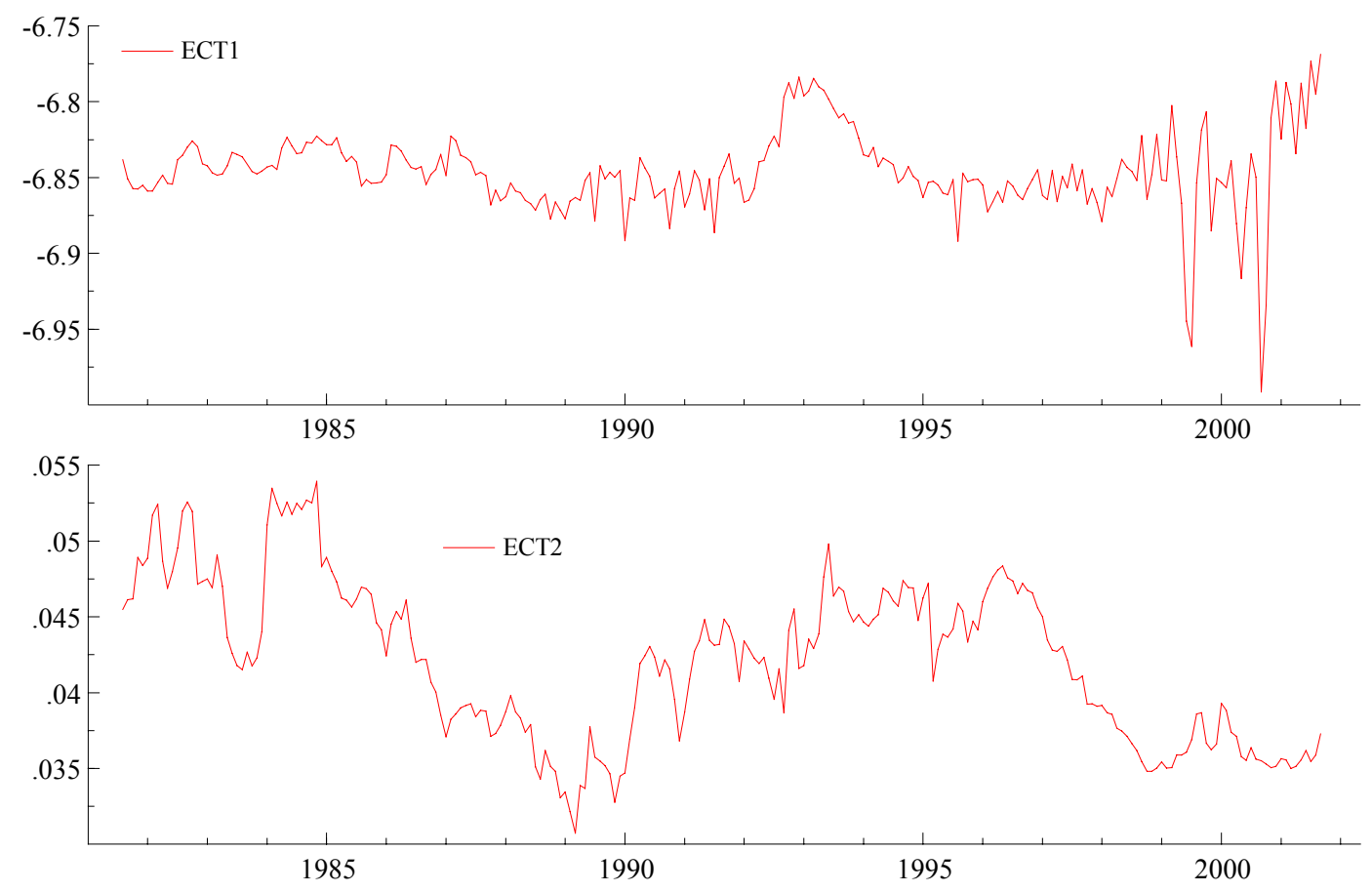
Chart AIII. 2: Recursive Chi-square test for the loan demand model

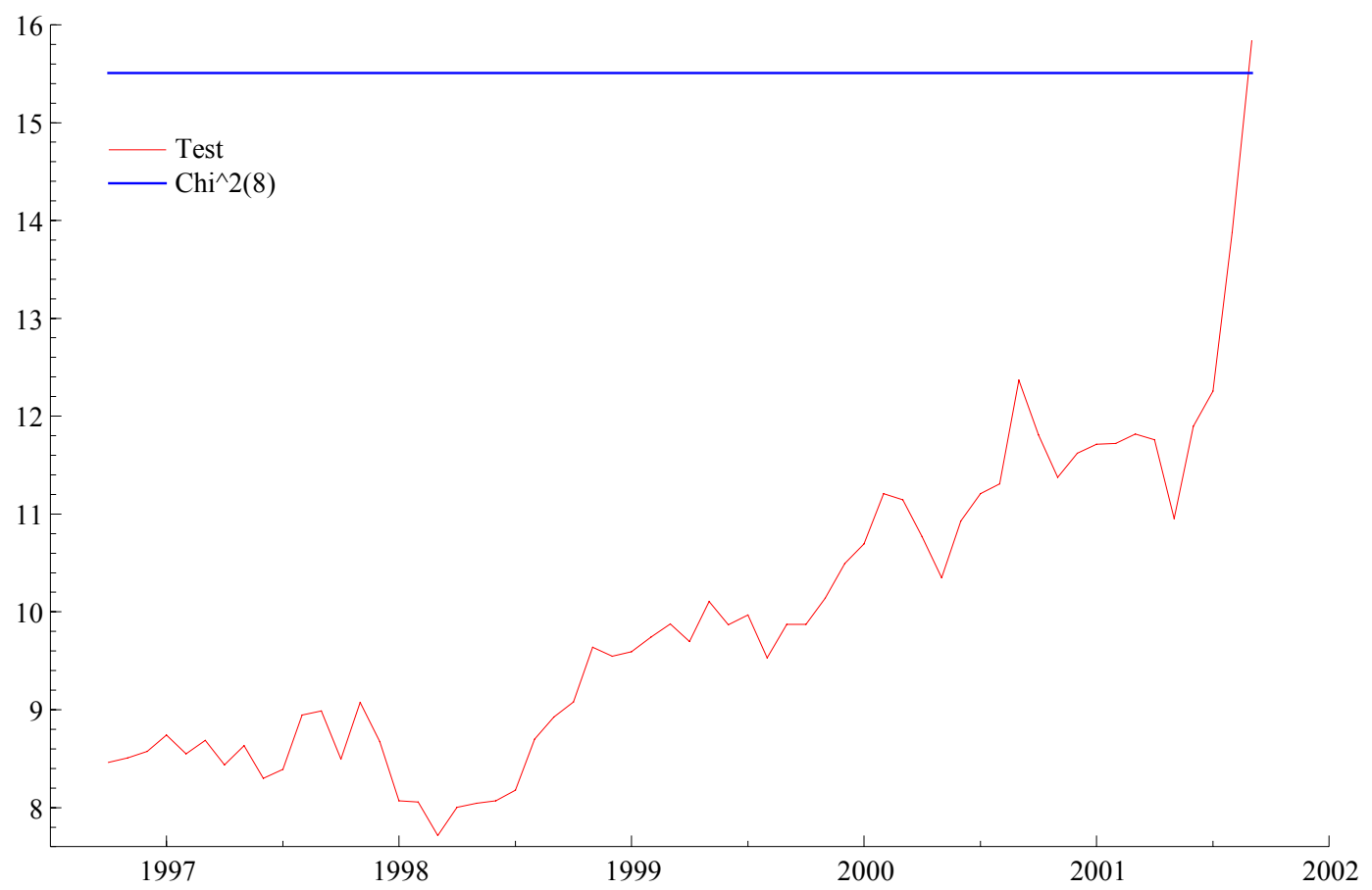


Appendix IV: Cointegration analysis: Encompassing monetary model

Table AIV. 1: Johansen's trace test for the encompassing model

\begin{tabular}{|c|c|c|c|c|c|}
\hline Rank & $\begin{array}{l}\text { Eigenvalue } \\
\text { with } \\
\text { dummies } \\
\text { and } \\
\text { exogenous }\end{array}$ & $\begin{array}{l}\text { Trace test } \\
\text { with } \\
\text { dummies } \\
\text { and } \\
\text { exogenous }\end{array}$ & $\begin{array}{c}\text { Trace test } \\
\text { without } \\
\text { dummies and } \\
\text { exogenous }\end{array}$ & $\begin{array}{c}\text { Critical Value } \\
\text { at } 95 \%\end{array}$ & $\begin{array}{l}\text { Critical Value } \\
\text { at } 95 \% \\
\text { corrected for } \\
\text { the exogenous }\end{array}$ \\
\hline 0 & & 163.6 & $142.72^{* * * *}$ & 124.2 & 140.5 \\
\hline 1 & 0.189 & 112.7 & $101.43^{* *}$ & 94.2 & 109.6 \\
\hline 2 & 0.133 & 78.04 & $69.31^{* *}$ & 68.5 & 81.45 \\
\hline 3 & 0.093 & 54.45 & $44.75^{*}$ & 47.2 & 58.63 \\
\hline 4 & 0.084 & 33.13 & 25.92 & 29.7 & 38.93 \\
\hline 5 & 0.073 & 14.76 & 8.96 & 15.4 & 23.32 \\
\hline 6 & 0.050 & 2.18 & 0.46 & 3.8 & 11.47 \\
\hline
\end{tabular}

Chart AIV. 1: Cointegrating vectors: demand for money, demand for loans, deposit rate pass-through, intermediation spread pass-through
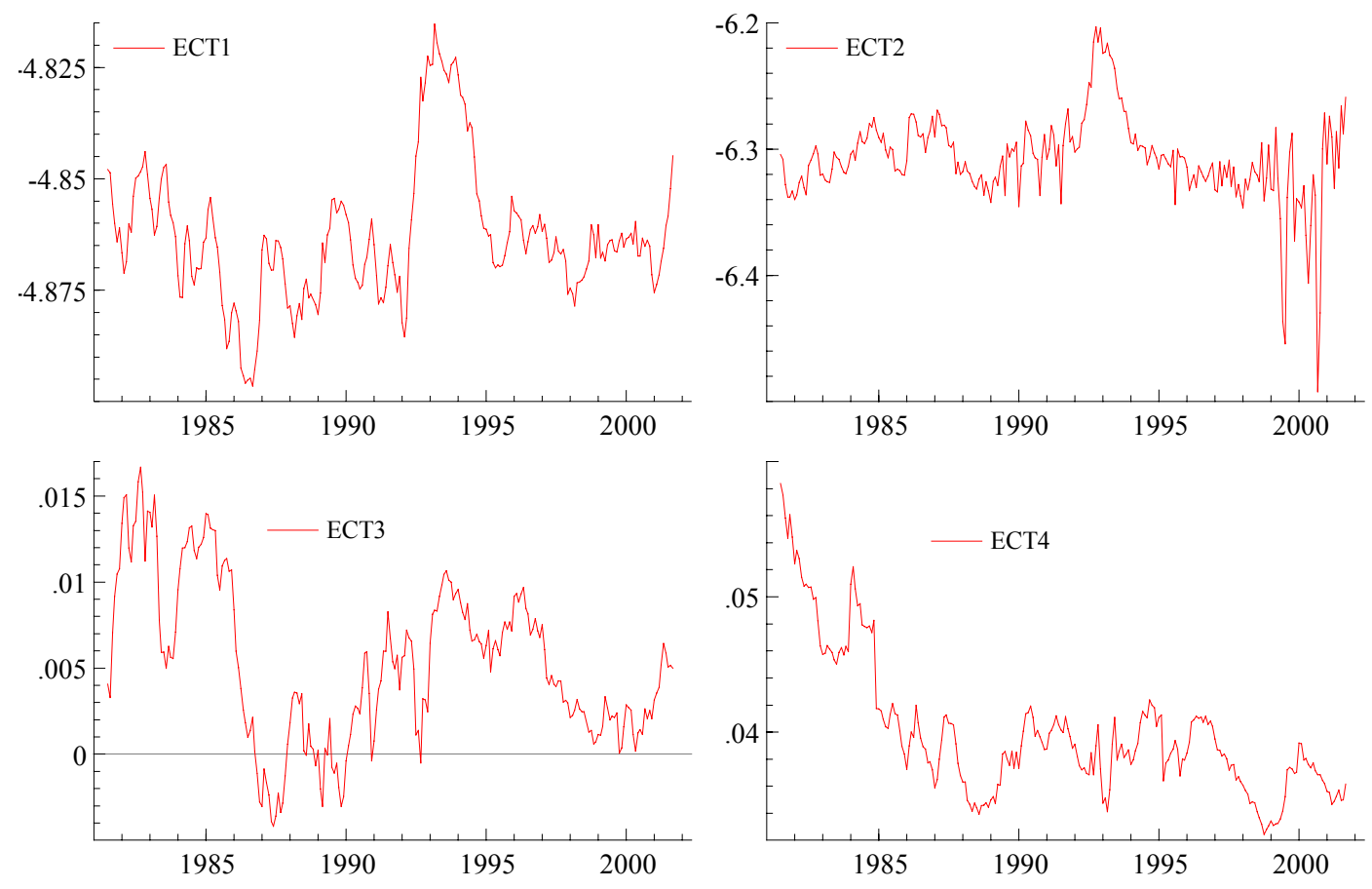
Chart AIV. 2: Recursive Chi-square test for the encompassing model

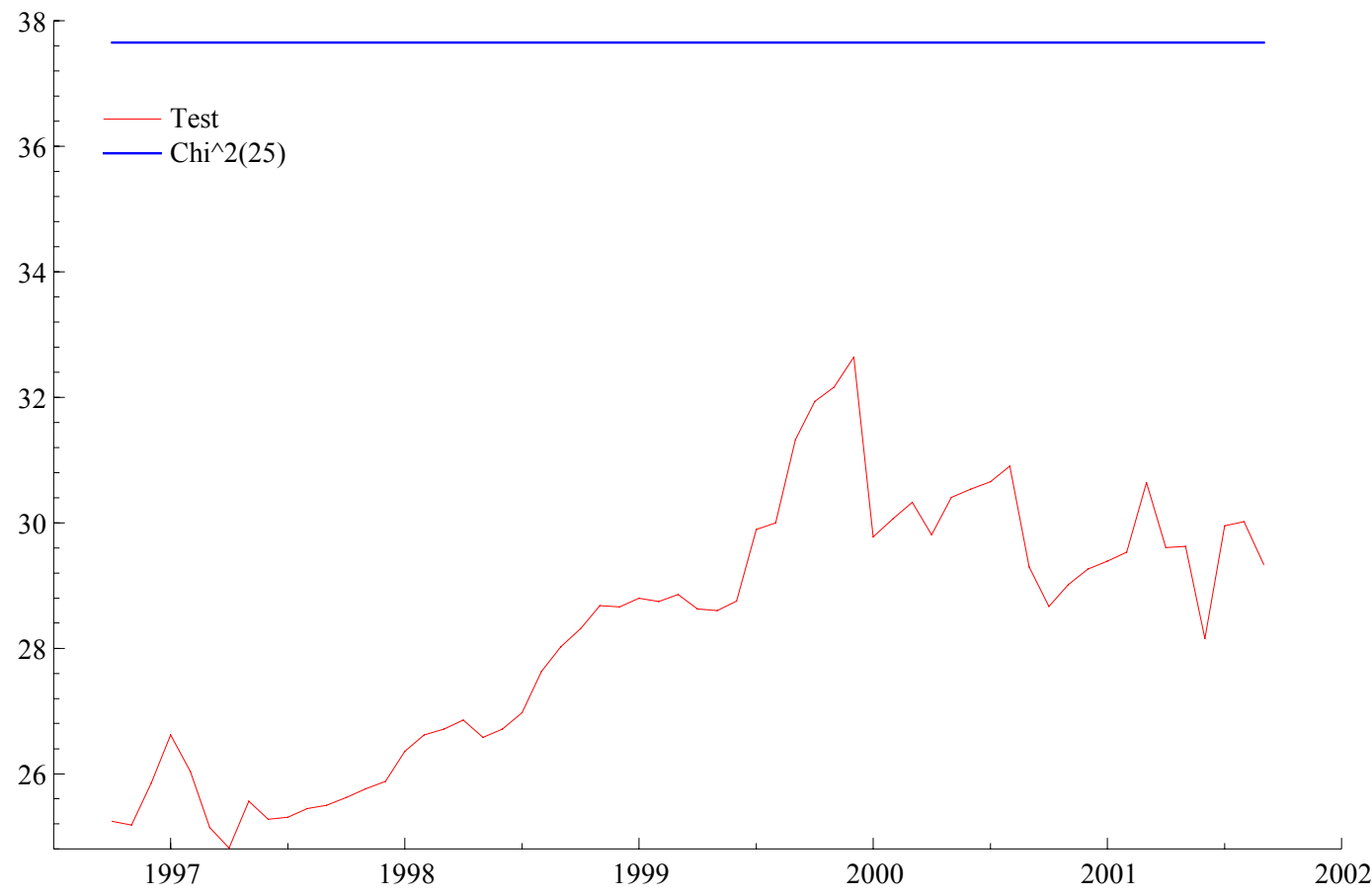




\section{Appendix V: Encompassing monetary model: FEVD}

\section{Chart AV. 1: Forecast error variance decompositions}
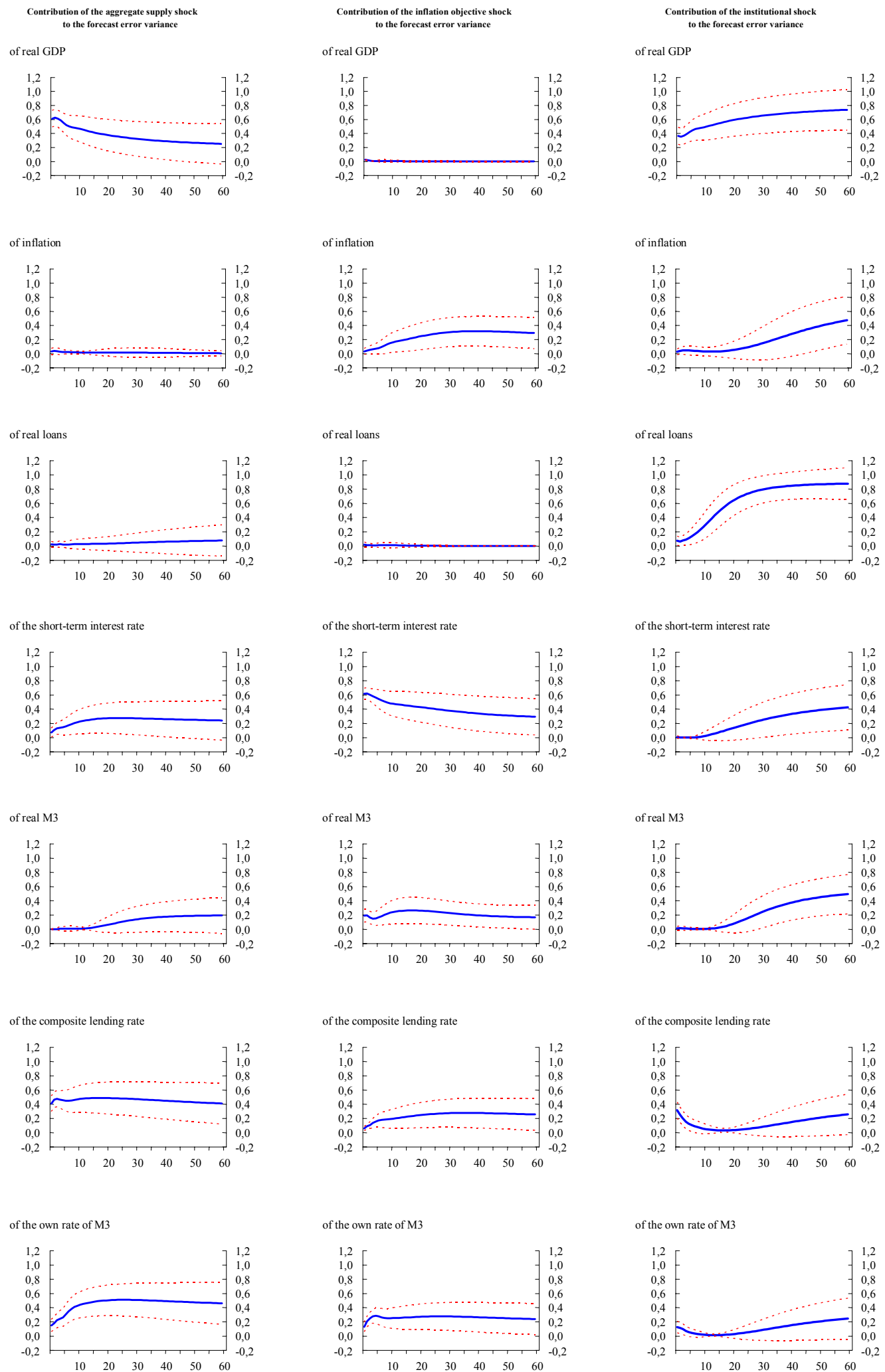

Note: Each column represents a permanent shock, from the left to the right, these shocks are the aggregate supply shock, the inflation objective shock and the institutional shock. The lines indicate the reaction of the different variables, from top to bottom, real GDP, inflation, real loans, the short-term market interest rate, real M3, the composite lending rate and the own rate of M3. $95 \%$ confidence intervals. 
Continuation of Chart AV. 1

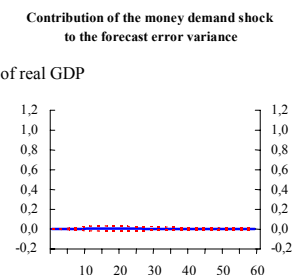

Contribution of the loan demand shock

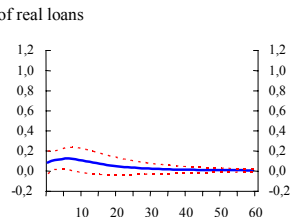

of the short-term interest rate

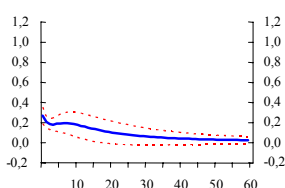

of real M3

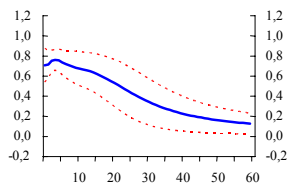

of the composite lending rate

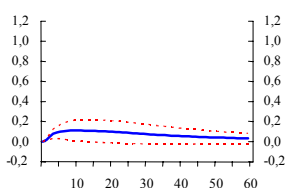

of the own rate of M3

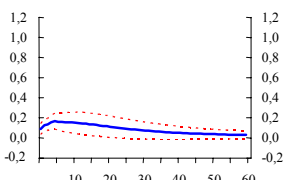

of real GDP
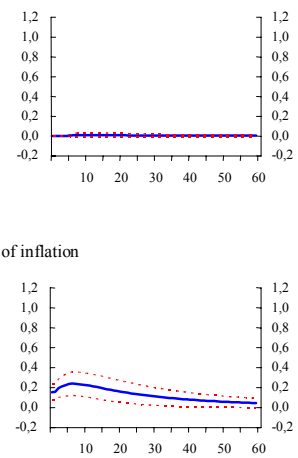

of real loans

Contribution of the banking shock

of real GDP
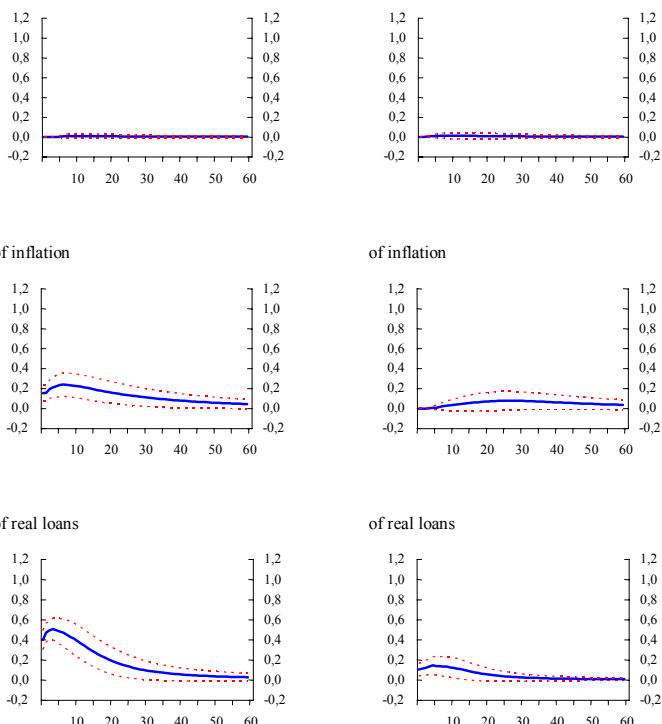

of the short-term interest rate

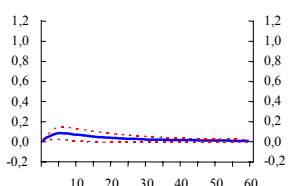

of real M3

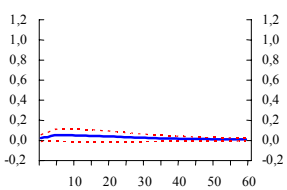

of the composite lending rate

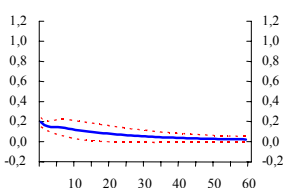

of the own rate of $\mathrm{M}$

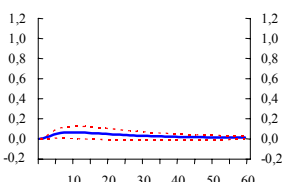

of real loans

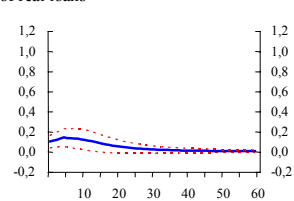

of real loans
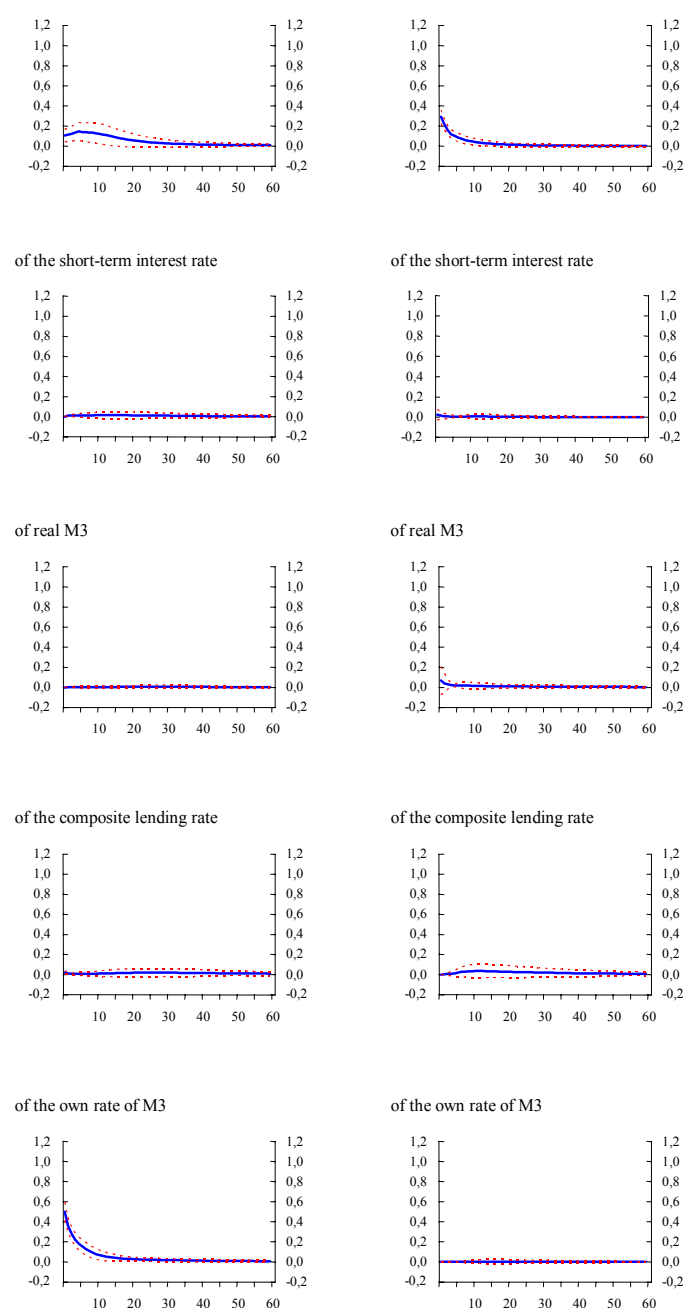

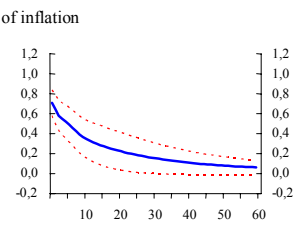




\section{Appendix VII: Money demand model: IRF and FEVD}

The order of the variables is the following one: real GDP, the short-term market interest rate, real M3 and the own rate of M3. In the columns we find the following shocks: the aggregate supply shock, the inflation objective shock, the money demand shock and the banking shock. The restrictions imposed are presented in the matrices below.

Long-run impact of permanents innovations: $\left[\begin{array}{ll}1 & 0 \\ 1 & 1 \\ 1 & 1 \\ 1 & 1\end{array}\right]$

Contemporaneous impact of temporary innovations: $\left[\begin{array}{ll}1 & 1 \\ 1 & 0 \\ 1 & 1 \\ 1 & 1\end{array}\right]$

\section{Chart AVI. 1: Impulse response functions}
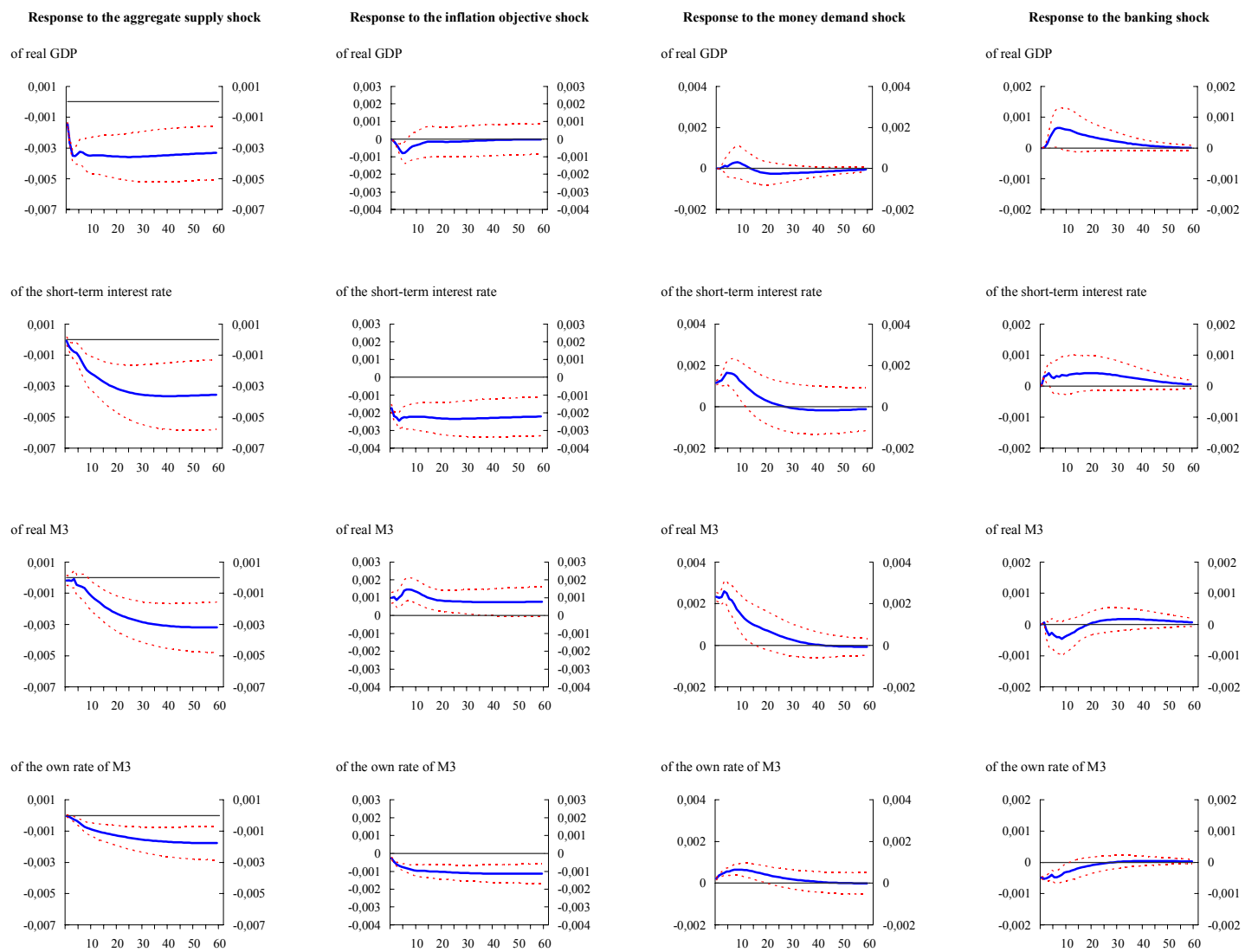

Note: Each column represents a shock, from the left to the right, these shocks are the aggregate supply shock, the inflation objective shock, the money demand shock and the banking shock. The lines indicate the reaction of the different variables, from top to bottom, real GDP, the short-term market interest rate, real M3 and the own rate of M3. 95\% confidence intervals. 
Chart AVI. 2: Forecast error variance decompositions

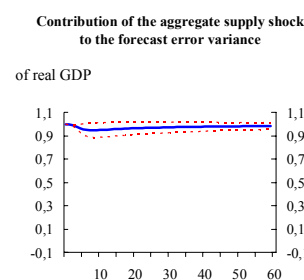

of the short-term interest rate
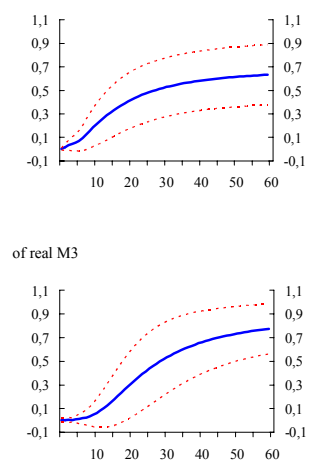

of the own rate of M3

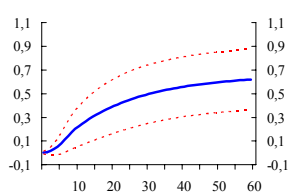

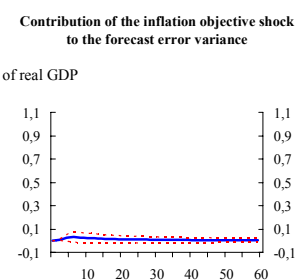

of the short-term interest rate

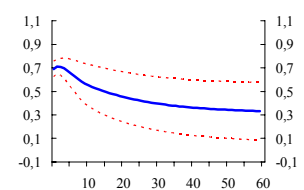

of real M3

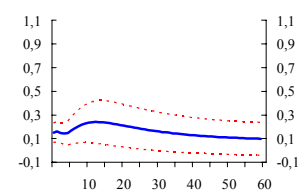

of the own rate of M3

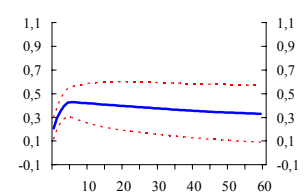

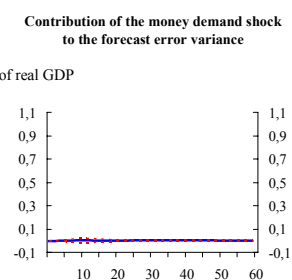

of the short-term interest rate
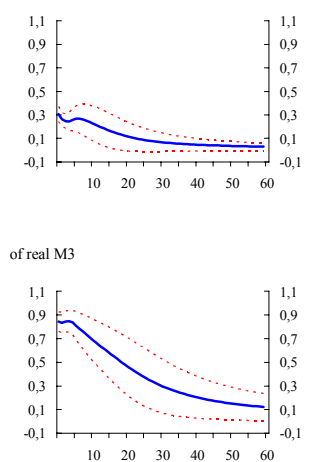

of the own rate of M3

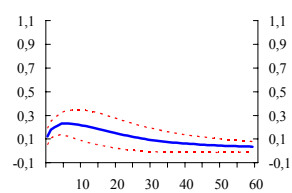

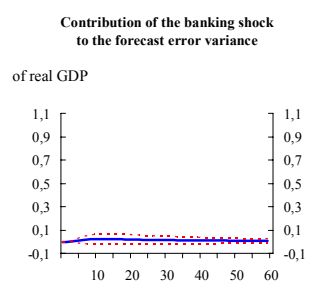
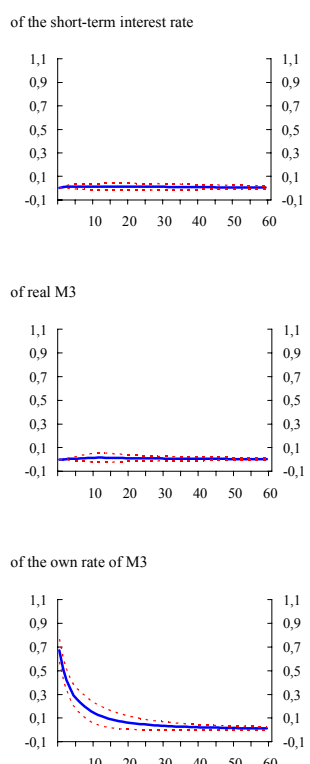

Note: Each column represents a shock, from the left to the right, these shocks are the aggregate supply shock, the inflation objective shock, the money demand shock and the banking shock. The lines indicate the reaction of the different variables, from top to bottom, real GDP, the short-term market interest rate, real M3 and the own rate of M3. 95\% confidence intervals. 


\section{Appendix VIII: Loan demand model: IRF and FEVD}

The order of the variables is the following one: real GDP, inflation, real loans, the composite lending rate and the short-term market interest rate. In the columns we find the following shocks: the aggregate supply shock, the inflation objective shock, the institutional shock, the loan demand shock and the interest rate shock. The restrictions imposed are presented in the matrices below.

Long-run impact of permanent innovations: $\left[\begin{array}{ccc}1 & 0 & 1 \\ 0 & 1 & 1 \\ 1 & 0 & 1 \\ 1 & 1 & 1 \\ 1 & 1 & 1\end{array}\right]$

Contemporaneous impact of temporary innovations: $\left[\begin{array}{ll}1 & 1 \\ 1 & 1 \\ 1 & 1 \\ 1 & 0 \\ 1 & 1\end{array}\right]$ 


\section{Chart AVII. 1: Impulse response functions}
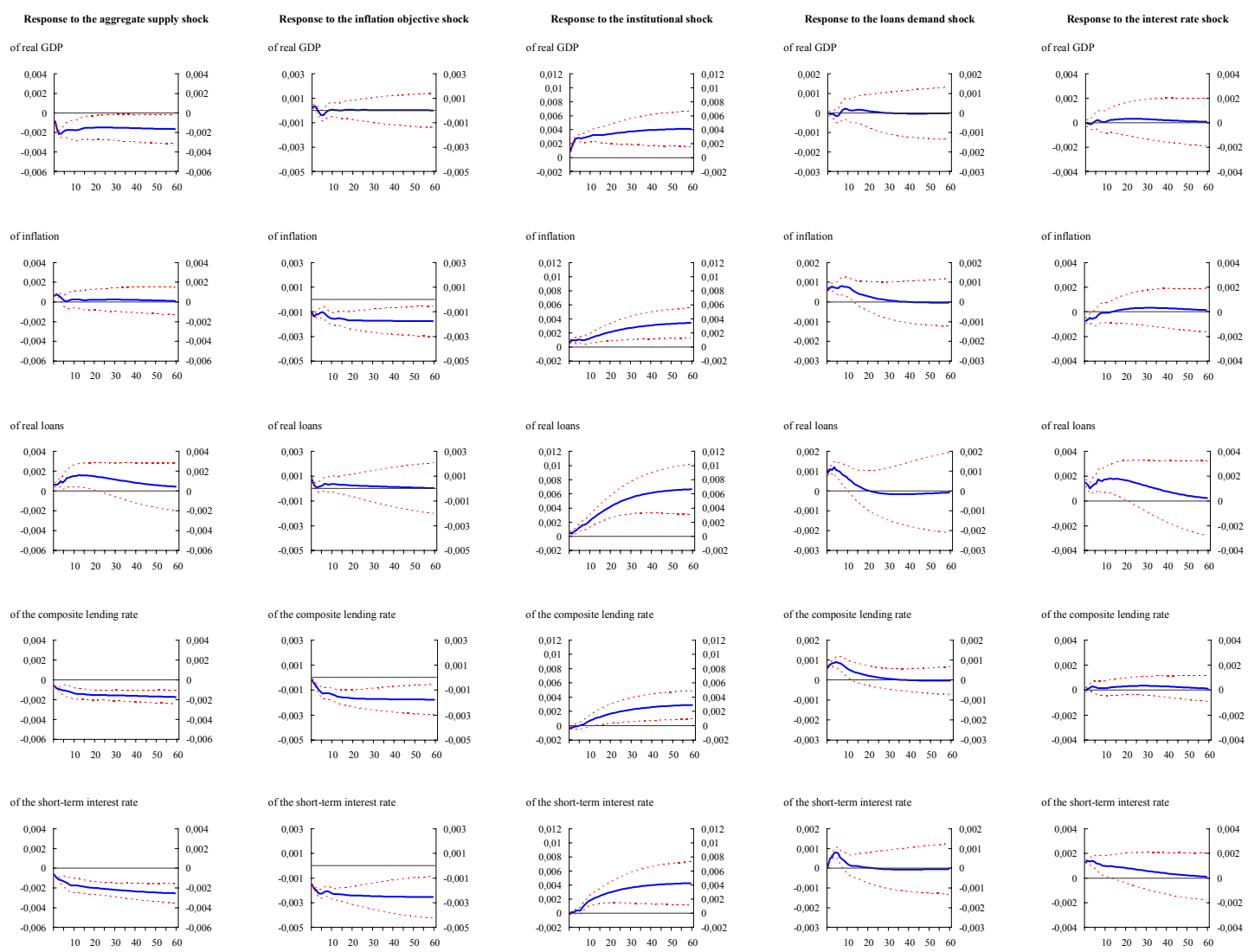

Note: Each column represents a shock, from the left to the right, these shocks are the aggregate supply shock, the inflation objective shock, the institutional shock, the loan demand shock, and the interest rate shock. The lines indicate the reaction of the different variables, from top to bottom, real GDP, inflation, real loans, the composite lending rate and the short-term market interest rate. $95 \%$ confidence intervals. 


\section{Chart AVII. 2: Forecast error variance decompositions}
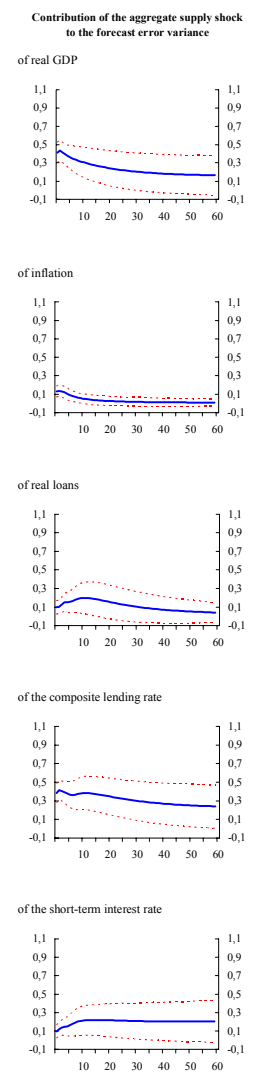
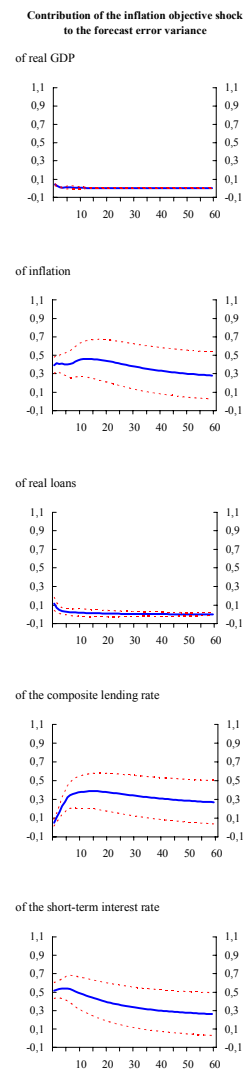
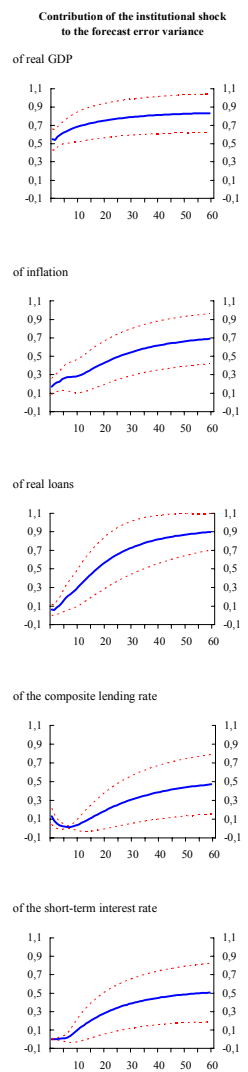
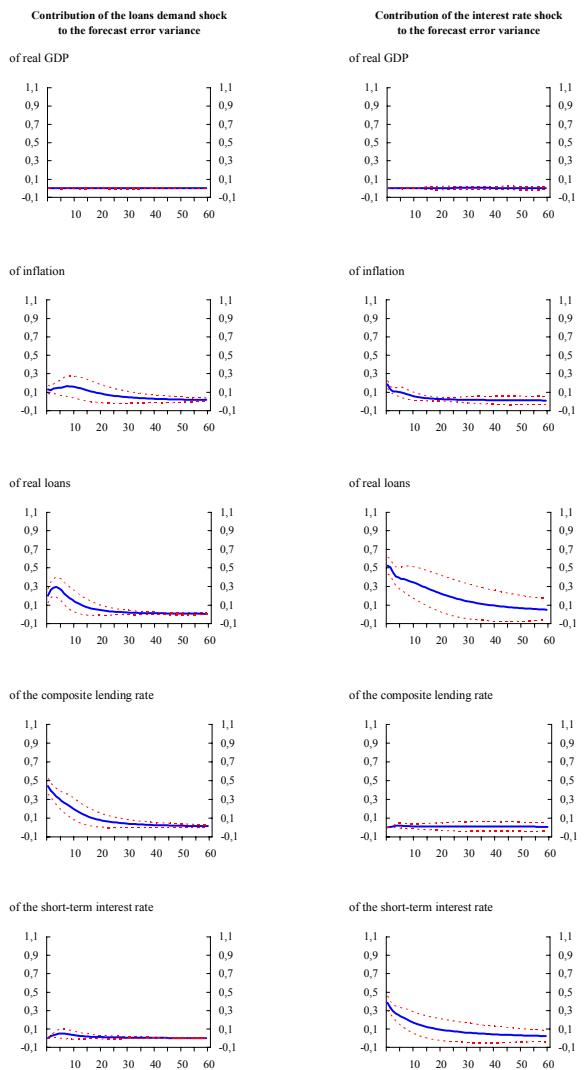

Note: Each column represents a shock, from the left to the right, these shocks are the aggregate supply shock, the inflation objective shock, the institutional shock, the loan demand shock, and the interest rate shock. The lines indicate the reaction of the different variables, from top to bottom, real GDP, inflation, real loans, the composite lending rate and the short-term market interest rate. $95 \%$ confidence intervals. 


\section{European Central Bank working paper series}

For a complete list of Working Papers published by the ECB, please visit the ECB's website (http://www.ecb.int).

202 "Aggregate loans to the euro area private sector" by A. Calza, M. Manrique and J. Sousa, January 2003.

203 "Myopic loss aversion, disappointment aversion and the equity premium puzzle" by D. Fielding and L. Stracca, January 2003.

204 "Asymmetric dynamics in the correlations of global equity and bond returns" by L. Cappiello, R.F. Engle and K. Sheppard, January 2003.

205 "Real exchange rate in an inter-temporal n-country-model with incomplete markets" by B. Mercereau, January 2003.

206 "Empirical estimates of reaction functions for the euro area" by D. Gerdesmeier and B. Roffia, January 2003.

207 “A comprehensive model on the euro overnight rate” by F. R. Würtz, January 2003.

208 "Do demographic changes affect risk premiums? Evidence from international data" by A. Ang and A. Maddaloni, January 2003.

209 "A framework for collateral risk control determination" by D. Cossin, Z. Huang, D. Aunon-Nerin and F. González, January 2003.

210 "Anticipated Ramsey reforms and the uniform taxation principle: the role of international financial markets" by S. Schmitt-Grohé and M. Uribe, January 2003.

211 "Self-control and savings" by P. Michel and J.P. Vidal, January 2003.

212 "Modelling the implied probability of stock market movements" by E. Glatzer and M. Scheicher, January 2003.

213 “Aggregation and euro area Phillips curves" by S. Fabiani and J. Morgan, February 2003.

$2 / 4$ "On the selection of forecasting models" by A. Inoue and L. Kilian, February 2003.

215 "Budget institutions and fiscal performance in Central and Eastern European countries" by H. Gleich, February 2003.

216 "The admission of accession countries to an enlarged monetary union: a tentative assessment" by M. Ca'Zorzi and R. A. De Santis, February 2003.

217 "The role of product market regulations in the process of structural change" by J. Messina, March 2003. 
218 "The zero-interest-rate bound and the role of the exchange rate for monetary policy in Japan" by G. Coenen and V. Wieland, March 2003.

219 "Extra-euro area manufacturing import prices and exchange rate pass-through" by B. Anderton, March 2003.

220 "The allocation of competencies in an international union: a positive analysis" by M. Ruta, April 2003.

22 I "Estimating risk premia in money market rates" by A. Durré, S. Evjen and R. Pilegaard, April 2003.

222 "Inflation dynamics and subjective expectations in the United States" by K. Adam and M. Padula, April 2003.

223 “Optimal monetary policy with imperfect common knowledge” by K. Adam, April 2003.

224 "The rise of the yen vis-à-vis the ("synthetic") euro: is it supported by economic fundamentals?" by C. Osbat, R. Rüffer and B. Schnatz, April 2003.

225 "Productivity and the ("synthetic") euro-dollar exchange rate" by C. Osbat, F. Vijselaar and B. Schnatz, April 2003.

226 "The central banker as a risk manager: quantifying and forecasting inflation risks" by L. Kilian and S. Manganelli, April 2003.

227 “Monetary policy in a low pass-through environment” by T. Monacelli, April 2003.

228 "Monetary policy shocks - a nonfundamental look at the data" by M. Klaeffing, May 2003.

229 "How does the ECB target inflation?" by P. Surico, May 2003.

230 "The euro area financial system: structure, integration and policy initiatives" by P. Hartmann, A. Maddaloni and S. Manganelli, May 2003.

23I "Price stability and monetary policy effectiveness when nominal interest rates are bounded at zero" by G. Coenen, A. Orphanides and V. Wieland, May 2003.

232 "Describing the Fed's conduct with Taylor rules: is interest rate smoothing important?" by E. Castelnuovo, May 2003.

233 "The natural real rate of interest in the euro area" by N. Giammarioli and N. Valla, May 2003.

234 “Unemployment, hysteresis and transition” by M. León-Ledesma and P. McAdam, May 2003.

235 "Volatility of interest rates in the euro area: evidence from high frequency data" by N. Cassola and C. Morana, June 2003. 
236 "Swiss monetary targeting 1974-1996: the role of internal policy analysis" by G. Rich, June 2003.

237 "Growth expectations, capital flows and international risk sharing" by O. Castrén, M. Miller and R. Stiegert, June 2003.

238 "The impact of monetary union on trade prices" by R. Anderton, R. E. Baldwin and D. Taglioni, June 2003.

239 "Temporary shocks and unavoidable transitions to a high-unemployment regime" by W. J. Denhaan, June 2003.

240 "Monetary policy transmission in the euro area: any changes after EMU?" by I. Angeloni and M. Ehrmann, July 2003.

24I Maintaining price stability under free-floating: a fearless way out of the corner?" by C. Detken and V. Gaspar, July 2003.

242 "Public sector efficiency: an international comparison" by A. Afonso, L. Schuknecht and V. Tanzi, July 2003.

243 "Pass-through of external shocks to euro area inflation" by E. Hahn, July 2003.

244 "How does the ECB allot liquidity in its weekly main refinancing operations? A look at the empirical evidence" by S. Ejerskov, C. Martin Moss and L. Stracca, July 2003.

245 "Money and payments: a modern perspective" by C. Holthausen and C. Monnet, July 2003.

246 "Public finances and long-term growth in Europe - evidence from a panel data analysis" by D. R. de Ávila Torrijos and R. Strauch, July 2003.

247 "Forecasting euro area inflation: does aggregating forecasts by HICP component improve forecast accuracy?" by K. Hubrich, August 2003.

248 "Exchange rates and fundamentals" by C. Engel and K. D. West, August 2003.

249 "Trade advantages and specialisation dynamics in acceding countries" by A. Zaghini, August 2003.

250 "Persistence, the transmission mechanism and robust monetary policy" by I. Angeloni, G. Coenen and F. Smets, August 2003.

25 I "Consumption, habit persistence, imperfect information and the lifetime budget constraint" by A. Willman, August 2003.

252 "'”Interpolation and backdating with a large information set" by E. Angelini, J. Henry and M. Marcellino, August 2003.

253 "Bond market inflation expectations and longer-term trends in broad monetary growth and inflation in industrial countries, 1880-200 I” by W. G. Dewald, September 2003. 
254 "Forecasting real GDP: what role for narrow money?" by C. Brand, H.-E. Reimers and F. Seitz, September 2003.

255 "Is the demand for euro area M3 stable?" by A. Bruggeman, P. Donati and A. Warne, September 2003.

256 "Information acquisition and decision making in committees: a survey" by K. Gerling, H. P. Grüner, A. Kiel and E. Schulte, September 2003.

257 “Macroeconomic modelling of monetary policy” by M. Klaeffling, September 2003.

258 "Interest rate reaction functions and the Taylor rule in the euro area" by P. Gerlach-Kristen, September 2003.

259 "Implicit tax co-ordination under repeated policy interactions" by M. Catenaro and J.-P. Vidal, September 2003.

260 "Aggregation-theoretic monetary aggregation over the euro area, when countries are heterogeneous" by W. A. Barnett, September 2003.

26I "Why has broad money demand been more stable in the euro area than in other economies? A literature review" by A. Calza and J. Sousa, September 2003.

262 "Indeterminacy of rational expectations equilibria in sequential financial markets" by P. Donati, September 2003.

263 "Measuring contagion with a Bayesian, time-varying coefficient model" by M. Ciccarelli and A. Rebucci, September 2003.

264 "A monthly monetary model with banking intermediation for the euro area" by A. Bruggeman and M. Donnay, September 2003. 